\title{
MINERALOGIA DE UMA TOPOSSEQUENNCIA DE SOLOS EM SEDIMENTOS RECENTES DA REGIÃO DO JEQUITAI - M.G.
}

JOSÉ ERNESTO SACCHI PESSOTTI

Orientador: JOSÉ LUIZ IORIATTI DEMATTÊ

Dissertação apresentada à Escola

Superior de Agricultura "Luiz de Queiroz", da Universidade de São Paulo, para obtenção do título de Mestre em Solos e Nutrição de Plantas.

P I R A C I C A B A

Estado de São Paulo - Brasil

Junho - 1980 
Aos meus pais, pelos esforços imensuraveis

A minhá esposa pelo apoio e dedicação

Aos meus filhos

Paulo Roberto

Luez Augusto

Elesane

Dedico 


\section{AGRADECIMENTOS}

Desejo manifestar aqui os meus sinceros agradecimentos as pessoas e instituições que direta ou indiretamente contribuiram para a realização deste trabaino.

- Ao Pnof. Dr. José Luiz Ioriatti Demattē, pela orientação e estĩmulo du rante este trabalho.

- Ao Departamento de Solos, Geologia e Fertilizantes que através do seu Centro de Estudos de Solos propiciou a obtenção das informações de cam po.

- Ao Prof. Dr. Arary Marconi pela colaboração na identificação dos minerais da fração areia.

- Ao Instituto de Geociēncias de São Paulo pela utilização de seu apareTho de Raios $X$.

- Aos professores do Departamento de Solos, Geologia e Fertilizantes pe10 esforço e dedicação na formação científica.

- Ao Prof. Dr. Guido Ranzani pela coláboração na escolha da ārea estudada.

- Ao meu colega e amigo jairo Roberto Jimenez Rueda pela intensa e valio sa colaboração.

- Ao meu amigo Josē Fernandes Gomes pela colaboração nos serviços de cam po.

- Aos funcionários do Departamento de Solos, Geologia e Fertilizantes: Nelci Teixeira Maniero pelos serviços datilográficos e Miguel Cēlio Hষ̣̀ polyto pela confecção das figuras. 


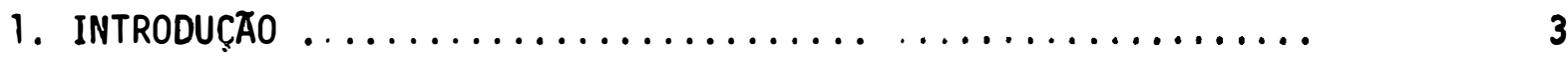

2. REVISAO BIBLIOGRAFICA $\ldots \ldots \ldots \ldots \ldots \ldots \ldots \ldots \ldots \ldots \ldots \ldots \ldots \ldots \ldots \ldots$

3. CARACTERISTICAS GERAIS DA AREA $\ldots \ldots \ldots \ldots \ldots \ldots \ldots \ldots \ldots \ldots$

3.1. Localização ............................. 8

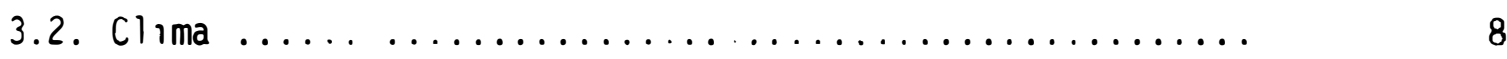

3.3. Geomorfologia e solos ...................... 10

3.4. Fundamentos do relevo local e estratıgrafia ......... 15

3.5. Geologia ..............................

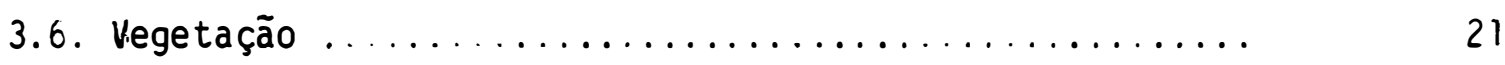

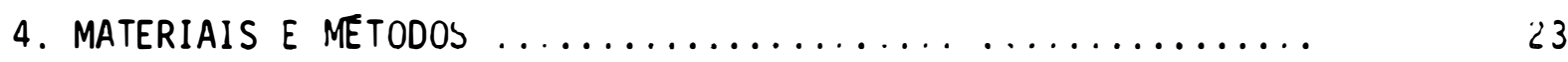

4.1. Seleção de àrea e amostragem ..................... 23

4.2. Aparelnos utı!ızados ........................ 24

4.3. Remoção de sais solüveis, matēria Jrgànica, $\mathrm{MnO}_{2}$ ?ivre e óxidos de ferro e manganês livre ................ 25

4.4. Dispersão e separação das diferentes fraçōes do solo.. 25

4.5. Preparo e montagem das amostras ................. 26

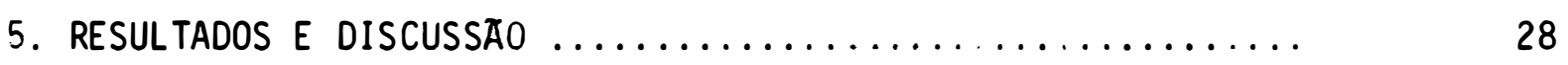

5.1. Mineralogia da fração areı ................... 28

5.2. Mineralogia da fração silte fino deferrado $2-20$ u)... 33

5.3. Mineralogia da fração argila deferrada ............. 40

5.4. Relação entre fisiografia e solos................ 59

5.5. Classificação dos solos ...................... 66 
iv.

Pàgina

6. CONCLUSÕES

68

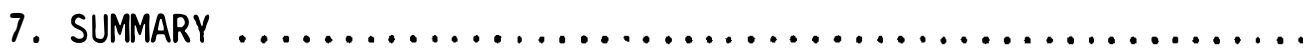

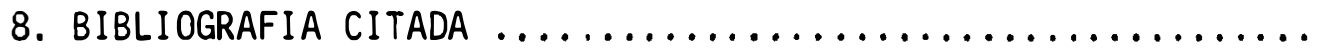

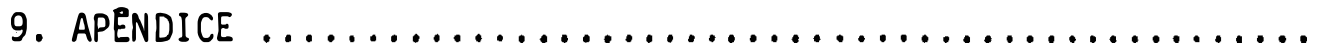


1 - Dados climáticos da região de Pirapora $\left(17^{0} 21 \mathrm{~S}\right.$ e $44^{\circ} 57^{\prime}$ W.Gr.), periodo 1931 a $1960 \ldots \ldots \ldots \ldots . . .11$

2 - Classificação dos solos ................... 24

3 - Anālise mineralōgica da fração areia em porcentagem de ocorrência de minerais ................

4 - Composição mineralógica e semi-quantitativa dos minerais da fração argila dos solos estudados ... 


\section{LISTA DE FIGURAS}

Pāgina

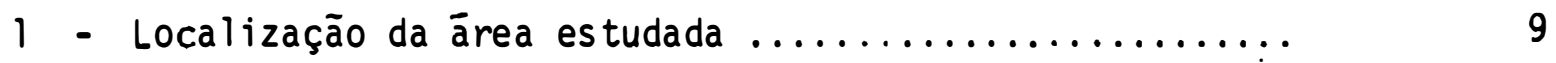

2 - Ba lanço hĩdrico da região estudada (Pirapora) ......... 12

3 - Corte esquemātico geológico, geomorfológico da região estudada e localização dos perfís ................ 17

4 - Mapa geolōgico da região $\ldots \ldots \ldots \ldots \ldots \ldots \ldots \ldots \ldots . . . . \ldots$

5 - Porcentagem de hornblenda + plagioclásios dos pedons em relação à distância do rio São Francisco .............

6 - Difratograma da fração silte fino (2-20 u) deferrada do pedon 1 ....................................

7 - Difratograma da fração silte fino (2-20 u) deferrada do

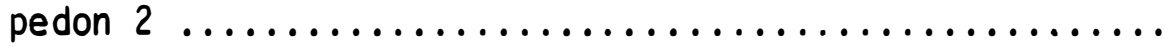

8 - Difratograma da fração silte fino (2-20 u) deferrada do

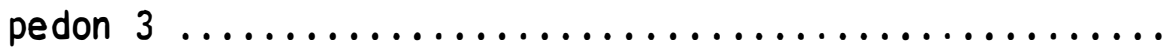

9 - Difratogramas da fração silte fino (2-20 u) deferrada

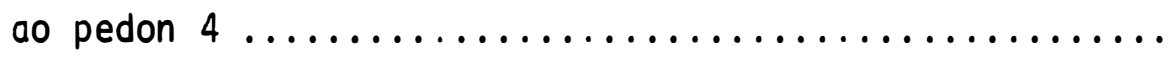

10 - Difratogramas da fração silte fino (2-20 u) deferrada

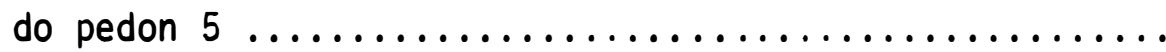

11 - Difratogramas da fração argila ( 2 u) deferrada do pe-

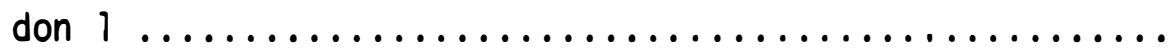

12 - Difratogramas da fração argila (< 2 u) deferrada do horizonte $B$ do pedon $1 \ldots \ldots \ldots \ldots \ldots \ldots \ldots \ldots . . . \ldots \ldots$

13 - Difratogramas da fração argila (< 2 u) deferrada do pe-

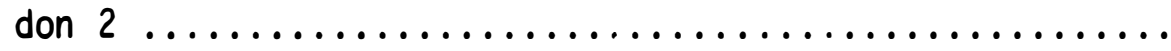


14 - Difratograma da fração argila (< 2 u) deferrada do horị

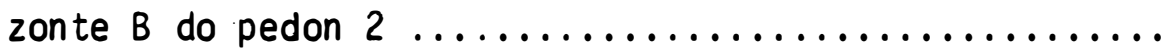

15 - Difratogramas da fração argila $(<2$ u) deferrada do ho-

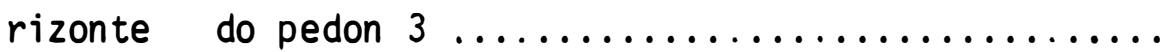

16 - Difratogramas da fração argila (< 2 u) deferrada do horizonte $B$ do pedon $3 \ldots \ldots \ldots \ldots \ldots \ldots \ldots \ldots \ldots \ldots \ldots \ldots \ldots \ldots \ldots$

17 - Difratogramas da fração argila (< 2 u) deferrada do pe-

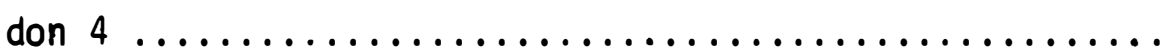

18 - Difratogramas da fração argila (< 2 u) deferrada do ho-

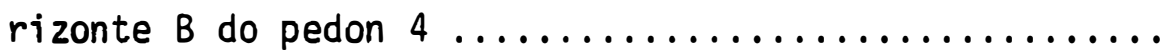

19 - Difratogramas da fração argila $(<2$ u) deferrada do pe-

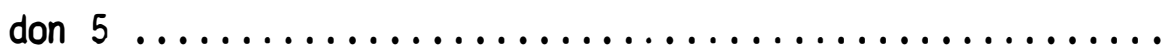

20 - Difratogramas da fração argila (< 2 u) deferrada do horizonte $B$ do pedon $5 \ldots \ldots \ldots \ldots \ldots \ldots \ldots \ldots \ldots \ldots \ldots \ldots \ldots \ldots \ldots \ldots \ldots$

21 - Corte esquemātico geomorfolōgico da ārea estudada evidenciando sequência e classe textural dos horizontes dos

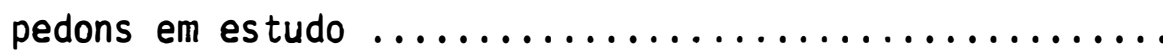

22 - Relação entre quartzo e plagioclāsios expressos em fun-

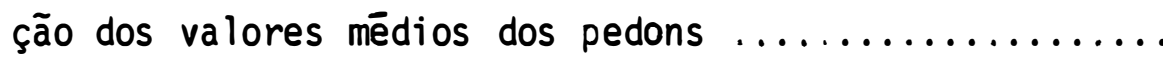


RESUMO

0 presente trabalno tem como objetivo o estudo mineralógico das frações areia, silte e argila de cinco perfis de solos evoluídos a par tir de sedimentos Ouaternārios de textura e composição variāveis, compondōo uma topossequência, que participaram de vários ciclos de erosão e deposi ção, sob a ação do rio São Francisco.

Os aspectos fisiogrä́ficos e sua correlação com os solos são abordados, evidenciando dentro da paisagem atual os efeitos destas interações. Na posição mais antiga (Pleistocênica), o solo apresenta-se em um es tágio de alteração intensa (pedon 1), enquadrando-se nas características evolutivas dos oxissolos (Typic Haplustox). Os demais pedons encontram-se sobre sedimentos Holocênicos, compondo a planĩcie aluvial do rio São Francisco. São solos mineralogicamente jovens porēm, morfologicamente ressaltam-se os processos pedogenéticos responsāveis pela formação de horizon tes argĩlicos (molissol e ultissol), contrariando as relações entre os sō los e a fisiografia que os admite em posições e sedimentos mais antigos.

Para o pedon 1 na fração areia os minerais primários facilmen te intemperizaveis inexistem. $\mathrm{Na}$ fração argila há dominância de caulinita, associada a mica $e$ interestratificados que aumentam em profundidade. 0 pedon 2 (Plinthic Haplustult) apresenta um acréscimo em profundidade de mine rais da fácil alteração para a fração areia. Para o silte fino o desapare- 
cimento dos feldspatos em superfície, sugere a sua al teração. A fração argila é predominantemente caulinítica com porcentagens pequenas de mica, in terestratificados e clorita em profundidade.

Os pedons 3 (Oxic Plinthaquult), 4 (Fluventic Plinthustult) e 5 (Fluventic Argiustoll) mostram elevadas proporções de minerais primá rios de fácil al teração (plagioclásios calco-sōdicos, hornblenda), na fração areia e silte. A ocorrência destes minerais associa-se a um processo deposicional recente, aliado as condições de clima e drenagem locais. Na fração argila, a caulinita é dominante, com valores decrescendo em profundidade, onde no mesmo sentido aumentam mica, interestratificados, vermiculita, montmorilonita e clorita. 
Com 0 intuito de enriquecer as escassas informações que a região sub-úmida brasileira apresenta atē o momento em relação à gênese dos solos, propôs-se a realização desse trabalho, talvez pioneiro, no vale do rio São Francisco.

A pretensão vem contribuir de uma maneira direta à somatória de conhecimentos do referido vale, pois, desde 1967 o governo federal,atra vēs do Plano Nacional de Irrigação, vem conduzindo trabalhos visando seu aproveitamento racional.

Não alheio a tais acontecimentos, o Departamento de Solos, Geo logia e Fertilizantes, a travēs do Centro de Estudos de Solos, em convênios. efetuados com a Companhia de Desenvolvimento do Vale do Rio São Francisco, vem proporcionando informações no tocante à classificação e mapeamento dos solos, e da adaptabilidade das terras à irrigação.

Por ocasião do levantamento semi-detalhado dos solos do Proje to Jequitaí-Divisão Jequitaí (CES, 1977), vārias topossequências foram ob servadas e utilizadas como critério no levantamento dos solos. Dentre tais topossequencias foi escolhida uma para estudos mais detalhados por ser de grande representatividade na região. Esta topossequência envolve mate- 
riais que a partir do terciārio estiveram sujeitos a vārios ciclos de erosão e deposição. Sobre tais sedimentos, que participaram de todo o histōri co evolutivo do vale do rio São Francisco, os fatores de formação de solos a tuaram em combinações diversas, promovendo as diferenças encontradas, na atualidade, entre os solos.

A finalidade deste trabalho è estudar uma topossequência representativa de solos evoluidos de sedimentos retrabalhados do final do terciārio, sob clima, atual sub-úmido, procurando:

a. Caracterizar a composição mineralógica das frações areia, silte e argila, e estudar o relacionamento mineralógico entre os solos.

b. Correlacionar as caracteristicas dos solos com a paisagem.

c. Classificar os solos. 
2. REVISAO BIBLIOGRAFICA

Os trabalhos existentes sobre o vale do rio São Francisco vi sam mais à classificação e utilização agrícola dos solos sob irrigação,não havendo, a tē o presente momento, citações a respeito da gênese e mineralogia desses solos.

Os projetos de estudos executados pela AID (1967) no vale do rio São Francisco, (em nĩveis generalizados), colocam de maneira geral os latossolos como dominantes sob vegetação de cerrado. Sob a deriominação de solos de Vārzea (AID, 2967), poucas informações são apresentadas. No levan tamento de reconhecimento dos solos do vale do rio Jequitai (RANZANI et alii, 1972) é evidenciada a dominância de latossolos seguida por Podzōli cos Vermelho Amarelo.

Segundo o Centro de Estudos de Solos CES, 1977) os solos da ārea ora em estudo classificam-se como Latossolo Vermelho Amarelo, Podzólico Vermelho Amarelo Plíntico, Gley Pouco Húmico e Brunizem Avermelhado, ao nivel de grande grupo.

JACOMINE (1965) cita que no Brasil, sob vegetação de cerrado, hā dominância de latossolos, com ampla variação textural. Este apontou 0 avançado estágio de intemperização desses solos com predominância de gibbsita, caulinita e goetita na fração argila. 
Estudos mineralógicos realizados por WEAVER (1974) em $\therefore$ seis perfis de latossolos, no planalto central do Brasil, possibilitaram a distinção de dois grupos de latossolos: um com dominância de caulinita e pequena quantidade de gibbsita; outro no qual a fração argila è predominante mente gibbsitica.

CAVALCANTI (1977), em investigações conduzidas no referido planalto, chegou às mesmas conclusões de WEAVER (1974), quanto à mineralogia da fração argila. Este autor realizou estudos mineralógicos na fração areia e os resultados mostram domínio absoluto de quartzo (99\%).

MONIZ e JACKSON (1967), estudando latossolos provenientes da decomposição de ardōsias, obtiveram para a fração argila desses solos valo res de $50 \%$ - $60 \%$ de gibbsita, contra apenas $10 \%$ - $30 \%$ de caulinita e $5 \%$ - $10 \%$ de materiais amorfos. Com base nos dados, estabeleceram a prova vel sequência de intemperização:

$$
\text { Ardōsia - Mica - Caulinita - Gibbsita. }
$$

Nos latossolos do planalto de Echaporã. (SP), estudados por LEPSCH et alii (1977) que, provavelmente, datam do Pieistoceno, encontramse quantidades de gibbsita inferior a $2 \%$. Isto vem concordar com os dados obtidos por CAVALCANTI (1977) para os latossolos que ocupam o que este denominou de segunda superfĩcie de erosão com altitudes superiores a 800 metros.

Ainda segundo LEPSCH (1977), no mesmo planalto, em uma super fỉcie de erosão atual (Holoceno), o solo estudado (Cambissolo) apresenta na fração areia valores de quartzo, diminuindo com a profundidade. No mesmo sentido hả um aumento de feldspatos, calco-sōdicos e mica. Para a fração argila foram diagnosticados minerais como a montmorilonita (20 \%-50\%). mica $(20 \%-50 \%)$, atapulgita e quartzo. 
Trabalhos de BALSTER e PARSONS (1968) e PARSONS e HERRIMAM (1975), citados por BILZI e CIOLKO\$K(1977), fazem menção de horizontes argílicos em seimentos aluviais recentes com idade de 2.350 a 5.250 anos . GILE e HAWLEY (1968) e GILE e GROSSMAN (1968), segundo a mesma citação,con cluem que na região do sudoeste Americano o horizonte argỉlico requer mais de 5.000 anos para se formar. NETTLETON et alii (1975) concluem que para a mesma região os horizontes argílicos ocorrem em superfície com mais de 12.000 anos.

BILZI e CIOLKOSZ (1977) concluem que, para os solos desenvolvidos em aluvião recente na Pensilvānia, são necessārios mais de 2.000 anos para a formação de argīlicos. 0 perfil de idade mais avançada $(1.500$ anos), mostrava características transicionais para argílico, sendo ainda enquadrado como horizonte câmbico. 


\section{CARACTERISTICAS GERAIS DA AREA}

3.1. Localização.

A área estudada situa-se ao norte do Estado de Minas Gerais, no al to durso do rio São Francisco. Pertence ao município de Várzea da Pal ma e encontra-se nas proximidades da vila da Barra do Guaicuí com as seguintes coordenadas geogräficas $17^{\circ} 11^{\prime} 34^{\prime \prime}$ latitude sul e $44^{\circ} 50^{\prime} 15^{\prime \prime}$ lon gitude W.Gr. A altitude varia entre 550 e 465 metros correspondendo ao vale do rio São Francisco.

A Figura 1 mostra a localização da ārea no Brasil e no Estade de Minas Gerais. A topossequência envolve a ärea entre a vertente direi ta do rio São Francisco e o sopē da Serra da Onça.

\subsection{Clima.}

Devido a inexistência de dados climáticos na área em estudo, utilizaram-se os parāmetros fornecidos pelas NORMAIS CLIMATOLOGICAS (1969), de Pirapora - MG, situada aproximadamente $13 \mathrm{~km}$ da região estudada. 
9.

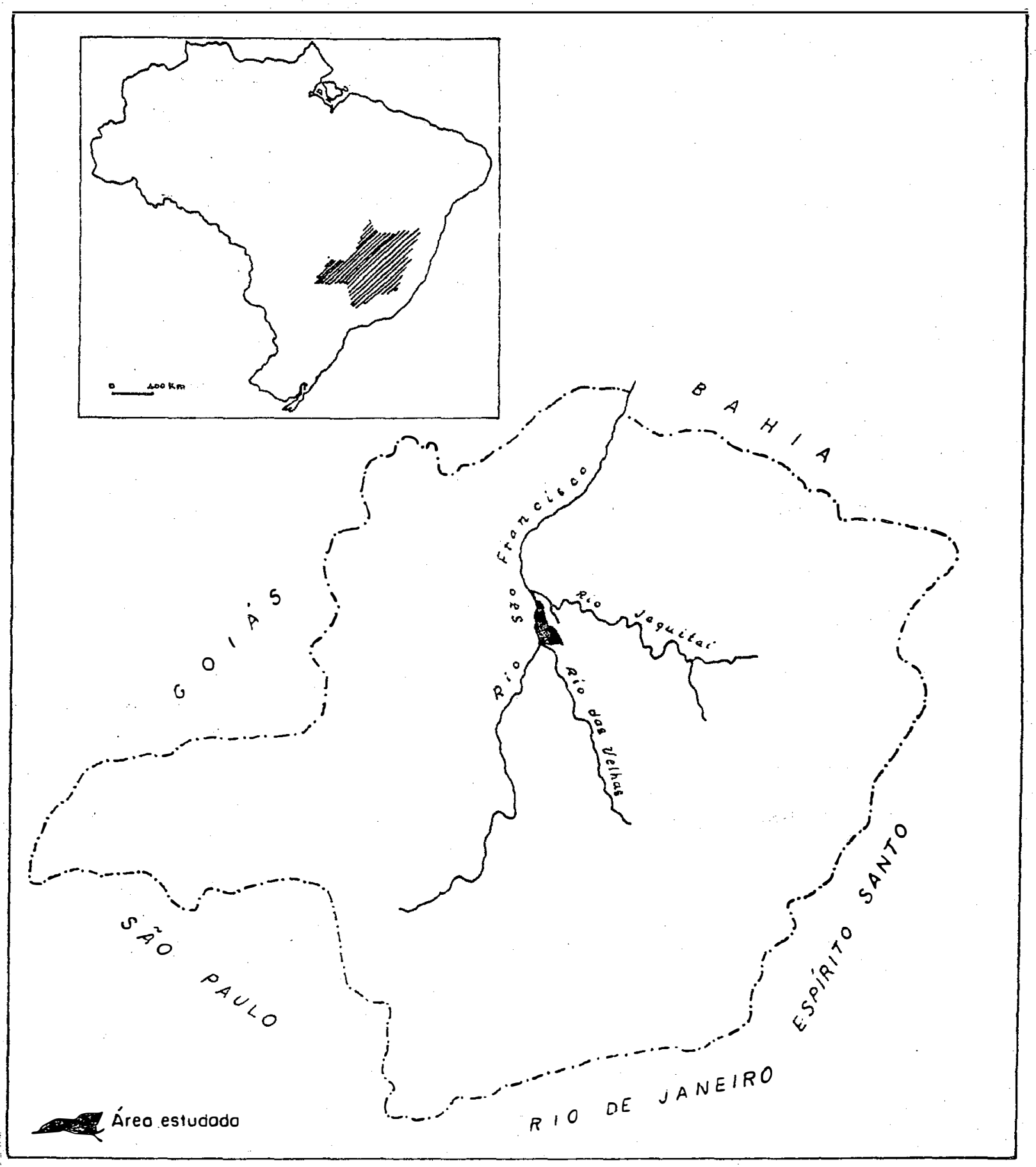

Figura 1. Localização da ārea estudada. 
Os dados de precipitação e temperatura são referentes ao perīodo de 1931 a 1960. As médias mensais constam do Quadro 1, além da estimativa da evapotranspiração mensal obtida segundo THORNTWAITE $e$ MATHER (1955). Estes dados permi tiram a elaboração do balanço hídrico de Pirapora representado pela figura 2. 0 clima da região è do tipo "sub-úmido" (THORN TWAITE, 1948) com uma precipitação anual de $1.145 \mathrm{~mm}$, assim distribuida:

$\begin{array}{lll}\text { - Primavera } & (S, 0, N) & \text { com 296 mm } \\ \text { - Verão } & (D, J, F) & \text { com 641 mm } \\ \text { - Outono } & (M, A, M) & \text { com 201 mm } \\ \text { - Inverno } & (\mathrm{J}, \mathrm{J}, \mathrm{A}) & \text { com } 7 \mathrm{~mm}\end{array}$

0 mês mais seco é agosto com $1 \mathrm{~mm}$ de precipitação, enquanto o mais úmido é dezembro com $278 \mathrm{~mm}$.

A temperatura média ē de $23,2^{\circ} \mathrm{C}$, enquanto que as médias de inverno e verão respectivamente 20,3 e $24,6^{\circ} \mathrm{C}$. 0 mês mais frio é julho com $19,7^{\circ} \mathrm{C}$ e 0 mais quente utubro com $25,3^{\circ} \mathrm{C}$. Como se observa, a diferença en tre as temperaturas médias de verão e inverno ē inferior a $5^{\circ} \mathrm{C}$.

A temperatura do solo medida diariamente a $50 \mathrm{~cm}$ de profundi dade, indicam valores menores que $5^{\circ} \mathrm{C}$ em relação a temperatura ambiente. (Informações verbais do posto meteorológico da Sudene - Pirapora).

Os parâmetros existentes, em confronto com os estipulados pe 10 SOIL TAXONOMY (1976), classificam o regime de umidade dos solos como "OSTICO" e o de temperatura "ISOTERMICO".

\subsection{Geomorfologia e solos.}

Atualizando referências de KING (1957), BRAUN (1971) efetuou estudos sobre os ciclos de erosão em que o Brasil esteve envolvido. Este verificou que o ciclo de erosão denominado Sul-Americano se processou em duas fases distintas: uma de desnudação ocorrida no Terciārio Inferior e outra de pediplanação no Terciário Médio. 


$$
\begin{aligned}
& \text { Quadro } 1 \text { - Dados climäticos da região de Pirapora }\left(17^{\circ} 215 \text { e } 44^{\circ} 57^{\prime} W_{0} G r\right) \text {, } \\
& \text { periodo } 1931 \text { a } 1960 .
\end{aligned}
$$

\begin{tabular}{lccc}
\hline Meses & $\begin{array}{c}\text { Precipitação } \\
(\mathrm{mm})\end{array}$ & $\begin{array}{c}\text { Evapotranspiração } \\
\text { potencial }\end{array}$ & $\begin{array}{c}\text { Tempera tura } \\
\text { média }(\mathrm{mm})\end{array}$ \\
\hline Janeiro & 220 & 126 & 24,7 \\
Fevereiro. & 143 & 112 & 24,9 \\
Março & 127 & 118 & 24,7 \\
Abri1 & 63 & 95 & 23,5 \\
Maio & 11 & 73 & 21,3 \\
Junho & 3 & 57 & 19,9 \\
Julho & 3 & 58 & 19,7 \\
Agosto & 1 & 75 & 21,5 \\
Setembro & 19 & 105 & 24,1 \\
Outubro & 75 & 126 & 25,3 \\
Novembro & 202 & 123 & 24,9 \\
Dezembro & 278 & 121 & 24,4 \\
Ano & 1.145 & 1.189 & 23,2 \\
& & & \\
\hline
\end{tabular}


12.

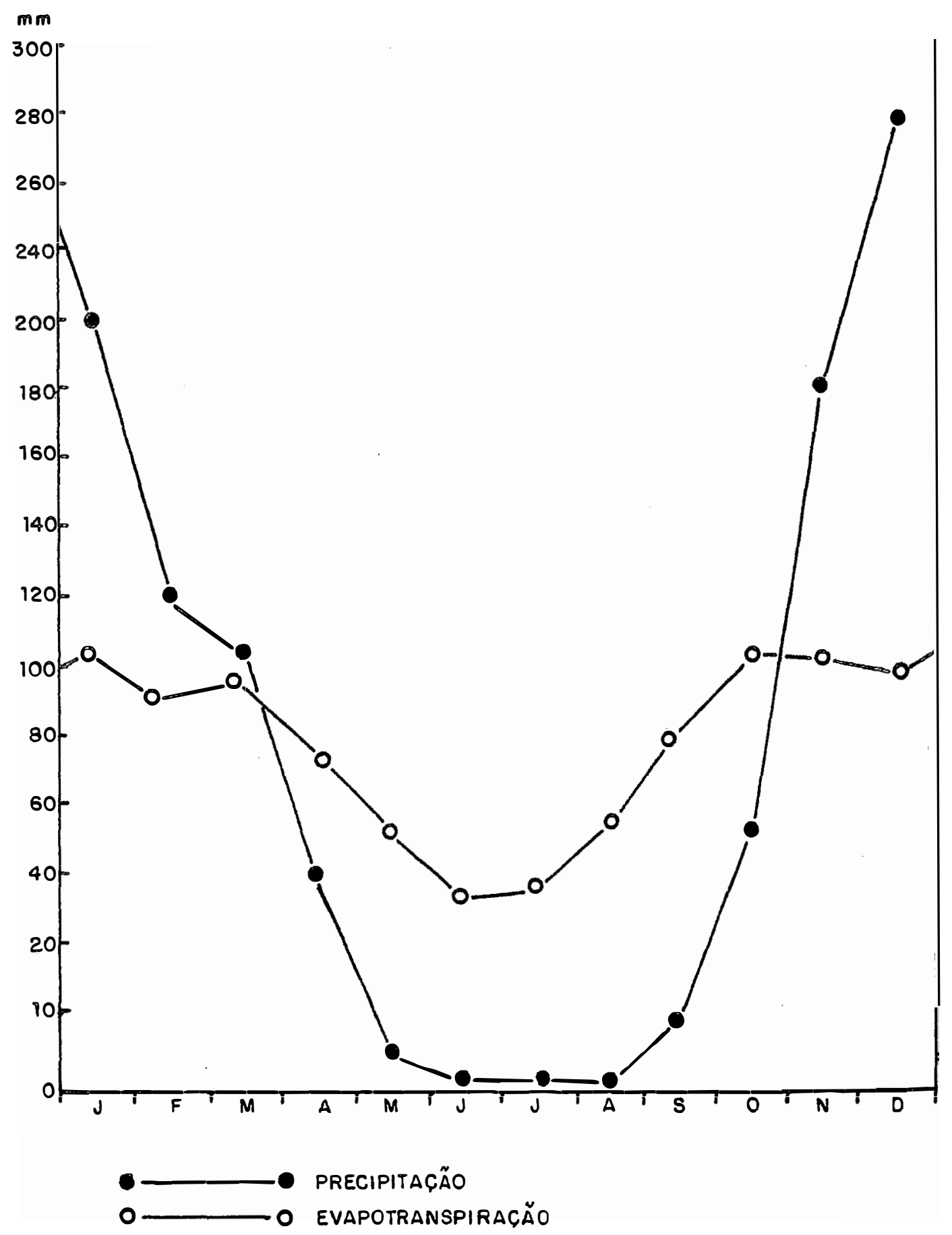

Figura 2. Balanço hĩdrico da reaião estudada (Pirapora). 
Esses processos arrasaram os relevos existentes, transforman do-os em uma extensa planīcie pontilhada de lagos e lagoas. Atravēs do soerguimento ocorrido a partir do Terciārio Médio, esta planīcie sujeitou-se aos ciclos erosivos (Ciclo Velhas) que sucederam do Terciārio Superior ao Quaternārio, destruindo a sua maior parte com o entalhe de inúmeros vales.

Os topos aplainados como o de Cristalina, a Chapada de Conta gem e Chapada dos Veadeiros (mais ou menos $1.200 \mathrm{~m}$ ) citados por BRAUN (1971), e a ārea representada pela Serra da Agua Fria, ramo ocidental da Serra do Cabral, no vale do rio São Francisco, (PENTEADO et alii, 1971)cor respondem à superfície Sul Americana de KING (1957).

As posições mais elevadas denominadas Superfícies Cristali nas (GEIGER, 1960) correspondem ao al to de uma dobra de fundo, situado en tre os geossinclíneos do Paranā e São Francisco. Segundo GEIGER (1960) foi RUELLAN (1952) o primeiro a chamar a atenção para o fato, assinalando no Planalto Central um bombeamento entre as linhas paralelas SE e NW. 0 mesmo paralelismo é citado por PENTEADO et alii (1971) na vertente esquerda do geossinclīneo São Francisco, mantido por quartzíticos e orto-quartzitos na altura da Serra da Ägua Fria.

Soerguimentos epirogênicos do Terciārio Superior foram os responsāveis pela formação deste relevo e o estabelecimento do ciclo erosivo das Velhas.

Movimentos tectônicos de afundamento ocorridos no Pleistoceno (KING, 1956) colocaram o fundo dos vales abaixo do nível dos planaltos adjacentes, possibilitando a formação da superfície do São Francisco de PENTEADO e RANZANI (1970). Para os vales do rio Jequitai e das Velhas este movimento tectônico repercutiu de forma escalonada. Os processos erosivos, além de marcarem as formas, deixaram evidências reconhecīveis na atua lidade em forma de carāter textural diversificado, presença de superfícies truncadas, com casos de paleossolos associados a camadas de seixos rolados. Tais evidências sugerem a existência de antigos terraços de origem estrutu ral. 
Os trabalhos realizados pelo Centro de Estudos de Solos na bacia do rio São Francisco abrangendo os afluentes Jequitaí (CES, 1971 e 1977), Corrente (CES, 1973), das Velhas (CES, 1974), além do efetuado pela RURALMINAS (1975), mostram a dominância de Ultissolos e Oxissolos para esta bacia.

PENTEADO e RANZANI (1970) são partidārios de condições bem mais secas para o clima passado. Se verdadeira tal suposição, os processos pedogenēticos de carāter quīmico tiveram sua atividade freada pela insuficiência de água. Assim, os solos desenvolvidos nas superfícies mais anti gas têm, como material parental, sedimentos de vārios ciclos de erosão e deposição, podendo estar o seu estágio correlacionado com elevado estágio de intemperização destes sedimentos.

PENTEADO e RANZANI (1970) fazem referências, para a região de Pirapora - Jequitaĩ no geossinclinal do São Francisco, à existência de vārias superfícies erosivas. A primeira com idade relativa Terciārio Inferior (Pd3 - Serra da Agua Fria) situado aproximadamente a 1.200 metros; a intermediária com altura superior a 800 metros (Pd2 - Serra da Onça) do Terciário Superior e, o pediplano recente (Pdl - Vale do São Francisco) do Pleistoceno médio com altitude inferior a 600 metros.

Os pediplanos Pd3 e Pd2 são ocupados por Latossolos Vermelho Escuro e Vermelho Amarelo (Oxissolos), variando texturalmente de medianos a argilosos. São de ocorrência comum Latossolos arenosos e dejeções de quartzo e canga na superficie Pd2.

No pediplano recente ( $P d l$ ) dos autores acima (provavel pedimento com marcas de terraços) a diversificação de solos ē grande, constata da por observações "in loco", havendo a domināncia de Podzōlicos Vermelho Amarelo, distróficos e eutróficos (Ultissolos e Alfissolos), seguidos de Latossolos distróficos (0xissolos). 
Nas bordas do anticlinal o calcārio do Bambuĩ se expõem e Mo lissolos são encontrados por intemperização e formação "in situ".

Generalizando, para a planicie aluvial Holocênica, os Incep tissolos e Entissolos a domina, conforme o tipo de sedimento e o grau de evolução apresentado.

Para a região estudada, 0 modelo de um pedimento retrabalhado por sucessivos terraços adapta-se melhor às condições existentes. A sērie Vazantes (PENTEADO e RANZANI, 1970) encaixa-se na forma de terraço deposicional (RUHE, 1975) e tem como contribuintes os sedimentos dos anti gos solos Terciários em avançado estágio de intemperismo. A presença de solos eutröficos nesta sērie pode ser explicada por contaminações com materiais calcārios. Para a planície aluvial os sedimentos devem conter um menor grau evolutivo, já que as cabeceiras dos rios que drenam para a bacia alto São Francisco entalham na atualidade um número variado de forma ções rochosas distintas, que contribuem com minerais pouco alterados, ou com possibilidade de alteração.

\subsection{Fundamentos do relevo local e estratiarafia.}

Dentro da depressão São Francisco estudada por PENTEADO e RAN ZANI (1970), a região pesquisada encontra-se no mais recente pediplano desenvolvido sobre formações Cambro-Ordcvicianas por processo de meteoriza ção mecânica e escoamento em lençol, em condições de clima bem mais seco que o atual, e è denominada Superfīcie ce São Francisco (PENTEADO, 1972).

Esta superfície apresenta-se recoberta por depösitos arenosos, frequentemente assentes sobre cascalheira de quartzo e canga, remanejados de antigos solos desenvolvidos sobre materiais paleozóicos da bacia. De acordo com os mesmos autores, esta fase de pediplanação foi colocada por cronologia relativa no Pleistoceno Médio, sendo que, no final deste perīodo, um rebaixamento generalizado do eixo da bacia possibilitou a deposição 
16.

da Sërie Vazantes, e que sob a ação de retomadas erosivas atuais e ...subatuais, facultaram a formação dos terraços do referido rio.

A posição mais antiga nesta topossequência exibe um manto arenoso espesso em contato com cascalheira de quartzo e canga, numa profundidade variāvel, concordando com a citação anterior e, portanto, de idade Pleistocēnica.

Analisando a planỉcie aluvial pōs-pleistocênica, encontraose uma deposição arenosa que diminui da margem do rio São Francisco para o in terior da planicie, chegando inclusive a desaparecer completamente. Este sedimento arenoso apresenta caracteristicas diferentes, quando comparado com 0 da região pediplanada $(P d 1)$, e estā na atualidade recoberto por uma deposição recente sîltico-argilosa.

A presença do embasamento plíntico em substituição à camada arenosa em profundidade, se amarra à possibilidade da existência de condições lacunares que ocuparam a posição de um antigo leito abandonado por es te rio, hoje totalmente colmatado, sendo portanto, relicto de uma drenagem que jā não existe na atualidade.

A Figura 3 procura mostrar em um corte as diferentes posições fisiogrāficàs e os sedimentos que as compõem.

No Holoceno, necessärio se faz ressaltar que esta topossequên cia envolve duas superfícies distintas: uma, de erosão atual, situada no talus da Serra da Onça, onde, devido ao a centuado relevo, a instabilidade $\bar{e}$ alta e os fatores de.formação têm como antagōnico natural o processo ero sivo, mantendo-a constantemente rejuvenescida; a outra è deposicional e tem como representante a planicie aluvial, onde o processo aditivo atuou marcadamente num passado relativamente prōximo. Na atualidade os seus efei tos são evidenciados em āreas restritas e ocasionais. As marcas da evolu ção pedogênica, diferenciando solos, são perceptīveis nesta paisagem. 


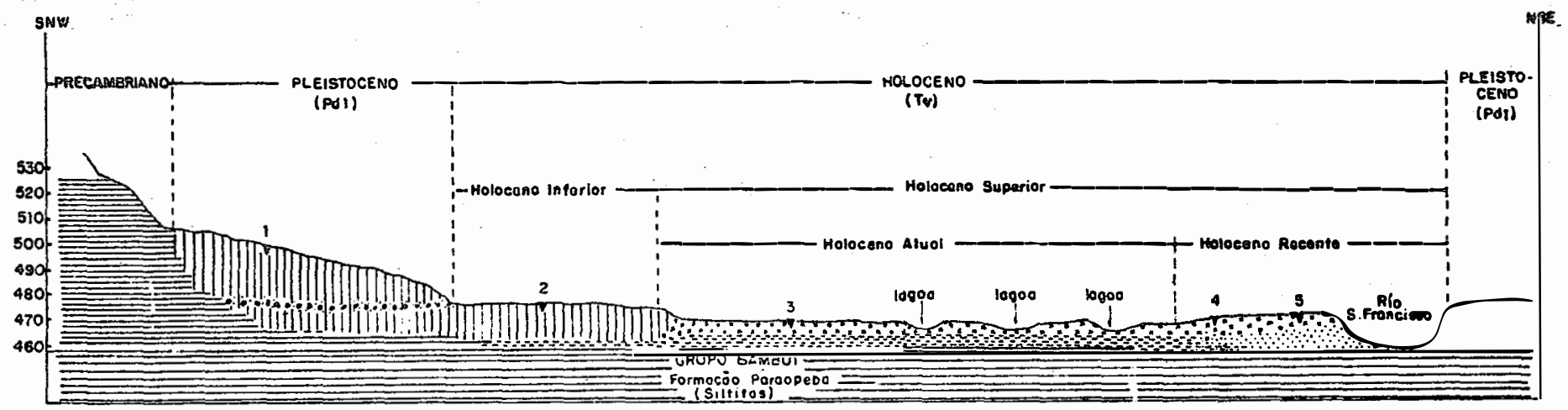

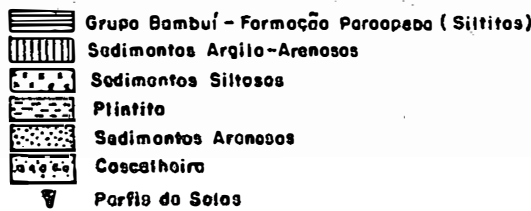

Figura 3 - Corte esquemātico geológico, geomorfolōgico da região estudada e localização dos perfis. 
Intercalado entre essas duas superfĩcies e exibindo sedimentos de um pāleo terraço ( $P d l)$, o material mais antigo (Pleistoceno) $\bar{e} 0$ ma is estāvel para o momento.

\subsection{Geologia,}

Os aspectos geológicos locais pouco influenciaram a composio ção mineralógica do material parental dos diferentes solos envolvidos nesta topossequēncia, por se tratar de uma área onde a sedimentação è de origem fluvial. A sedimentação causada pelo rio São Francisco nesta paisagem tem em seu conteūdo a contribuição das diferentes formações rochosas que compõem a bacia de seu alto curso.

Os trabalhos de PONÇANO e PAIVA (1972) e MATTOS e CUNHA (1977) fazem menção aos seguintes grupos e formações que constituem o embasamento geológico desta bacia:

Grupo Espinhaço - composto de arenitos, quartzitos, conglome rados, filitos e argilitos, de ocorrência nas serras do Espinhaço e Cabral.

Formação Jequitaĩ - representada por diamictitos na região de Jequitaī e também por arenitos conglomeráticos assentados sobre quartzi tos na borda ocidental e oriental da serra do Cabral, estendendo-se ao nor te na serra Agua Fria; nas exposições os diamictitos são rochas de coloração cinza-escura com poucos seixos de quartzito e sîlex com caracterīsti cas texturais de má seleção granulomētrica e angulosidade, sugerindo origem glacial.

Grupo Bambuĩ - este grupo geológico compreende as formações Paranoā (inferior), Paraopeba (intermediāria) e Trēs Marias (topo)。As for mações Paraopeba e Três Marias são as mais expressivas. 
Formação Paraopeba - a sua litologia è vapiada, contendo cal cários, quartzitos, siltitos, margas, argilitos e ardösias.

Formação Três Marias - assentado sobre a formação Paraopeba. os seus extratos são horizontais compostos de arenitos finos, sĩlititos ar cōseos。

Formação Urucuia - assenta-se sobre rochas do grupo Bambuî em discordância erosiva. São sedimentos cretácicos com dominância de areni tos endurecidos. Aparece como testemunha na paisagem geral devido à resistência adquirida por processos que envolveram silicificação e ou laterização.

Cobertura Terciārio-Quaternārio - capeiam indiscriminadamente quase todas as unidades geológicas. São coberturas detrîticas geralmente cascalhentas de textura argilo-arenosa, podendo chegar à espessura de 10 a 15 metros, distribuindo-se em extensos chapadões de morfologia suave entre relevo regional acima de 550 metros de altitude.

Depōsitos Quaternärios - envolvem os sedimentos aluviais recentes, acompanhando as calhas dos rios e os terraços fluviais. Nos rios São Francisco, das Velhas e Jequitaĩ, estes depōsitos são de grande amplitude textural, podem ir de cascalhentos a areno-argilosos e ou siltico-argilosos.

A Figura 4 mostra a representação espacial das formações geo lögicas que contribuĩram para a formação dos sedimentos da ārea em estudo. 


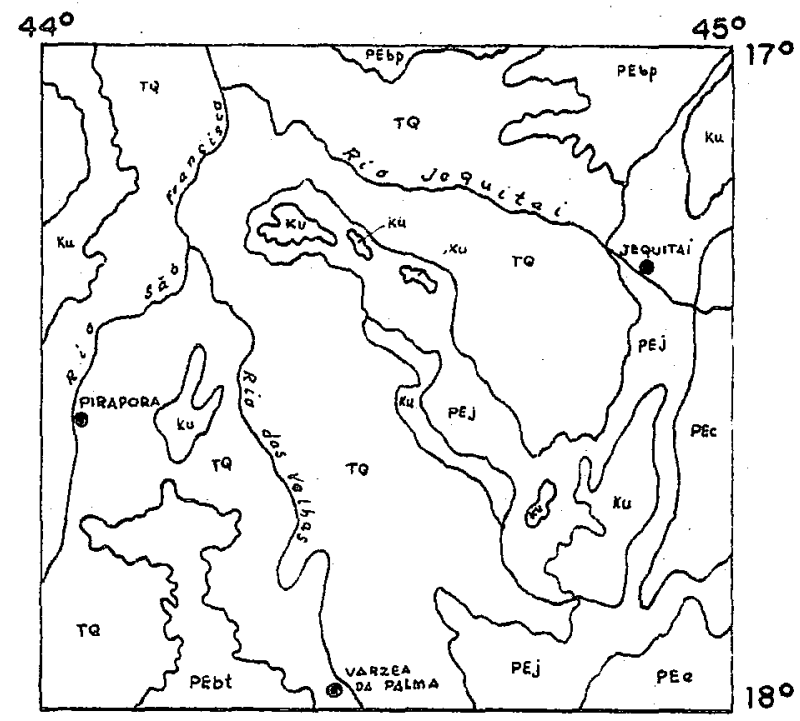

\section{LEGENDA}

\section{CENOZÓICO}

TQ COBERTURAS DETRITICO-LATERÍTICAS - areios, siltes, argilos, lateritos, etC.

$T$ DEPÓSITOS TERCIÁRIOS - sedimentos arenosos amarelos e overmelhados

MESOZÓICO

KU FORMAÇĀO URUCUIA - arenitos rosodos e overmelhados, intercaloções de folhelhos

Ka FORMACÃO AREADO - orenitos rosados com estratificação cruzado conglomerado basal PRECARBRIANO SUPERIOR

PEbt GRUPO BAMBUI - FORMAÇÃO TRES MARIAS - arcóseos, siltitos, arenitos finos PEbP FORMACÃO PARAOPEBA - calcários, ardósios, filitos, siltitos, arcóseos, margas, folhelhos

PEC GRUPO CANASTRA - filitos a quartzitos

PRECAMBRIANO INFERIOR E MÉDIO

PEj FORMACÃO JEOUITAI - diomictitos, orenitos, filitos

PEe GRUPO ESPINHACO - orenitos, quartzitos, conglomerados, filitos

Figura 4 - Mapa geológico da região. 


\subsection{Vegetação}

Ocupando indiscriminadamente posições antigas ou recentes, 0 cerrado è a comunidade vegetal dominante, não correlacionando, assim, nesta ärea, com mudanças, quer da paisagem, quer dos solos. Apresenta car
do clima sub-ümido atual.

Apresenta caracterỉsticas decỉduas impostas pelas condições

- Dentro da sua composição florīstica, poucas espécies foram preservadas pelo uso, e assim, entre os remanescentes dominam o Piqui (Caryocar brasiliense St. Hil), Pau-terra (Qualea grandiflora Mart.), Sambaiba (Curatella americana Linn), além de outras não identificadas, porēm de menor expressão。

Acompanhando o curso do rio São Francisco, em certas āreas. depara-se ainda com uma floresta ciliar aparentemente não decīdua como se: identificam facilmente a Aroeira (Schimus sp.) Pau-ferro (Gassalpiniaferrea), Jatobä (Hyminea courbaril Linn) e outras. Nota-se a ação antropo gênica contribuindo para alargar o territōrio do cerrado, pois espaços que antes pertenciam a esta formação florestal, hoje se encontram sob seu domi nio.

Em pequena proporção, e em posições sujeitas a inundações oca sionais no periodo chuvoso, a campina de vārzea se faz presente, exibindo gramineas variadas bastante duras.

0 teor de matéria orgânica encontrado nos solos sob florestas ciliares é no geral bastante elevado. Isto decorre das condições microclimáticas existentes nas proximidades dos rios, que permitem a manutenção de condições vegetativas praticamente 0 ano todo, facultando um meio propīcio à interação dos processos biodinâmicos entre solo-planta. A capitação de elementos pela cobertura vegetal, as transformações processadas e o posterior retorno à superfīcie do solo, comportam-se como uma fonte de adição 
exclusiva (SIMONSON, 1959). A decomposição imposta pela atividade microbia na e a incorporação constante ē uma fonte de energia para a aceleração dos processos intempéricos. E uma contribuição de forma lenta e contīnua para o desenvolvimento e diferenciação de horizontes e solos. 
23.

4. MATERIAIS E METODOS

4.1. Seleção de ārea e amostragem

Fundamentalmente, esta ārea foi selecionada por conter em um pequeno espaço físico, materiais que participaram atē o momento da evolu ção sofrida pelo vale do rio São Francisco.

A separação dos diferentes aspectos da paisagem, foi feita com 0 auxîlio de fotos aéreas preto e branco em escala 1:25.000, procedentes da cobertura fotogrāfica realizada pela cruzeiro do Sul em 1967. Os 1i mites traçados na fotointerpretação prévia foram aferidos por sucessivas incursões ao campo.

Uma vez completa a delimitação em ārea representativa dos so los componentes de cada posição fisiogräfica, procedeu-se à abertura de trincheiras, com dimensões de $2 \times 1,5 \times 1,5$ metros, perfazendo ao todo cin co perfís e enumerados de 1 a 5 .

Nas descrições morfológicas dos perfís de solos, foram adota das as normas preconizadas pelo Soil Survey Manual (1951), sendo que na de signação dos horizontes utilizou-se a nomenclatura a ser publicada pelo SOIL TAXONOMY. 
Dos diferentes horizontes de cada solo, foram coletadas amostras de terra e acondicionadas em sacos plásticos com capacidade aproximada de $2 \mathrm{~kg}$, para futuras determinações analíticas. A classificação destes solos pelo Sistema Brasileiro se encontra no Quadro 2.

Quadro 2 - Classificação dos Solos.

\begin{tabular}{|c|c|}
\hline Pedon nọ & Classificação \\
\hline 1 & $\begin{array}{l}\text { Latossolo Vermelho Amarelo, Epieutrófico, Alico, A fraco, } \\
\text { textura média (LVA). }\end{array}$ \\
\hline 2 & $\begin{array}{l}\text { Podzólico Vermelho Amarelo Plíntico, Epieutrōfico, Alico, } \\
\text { A moderado, textura argilosa (PVA pli) }\end{array}$ \\
\hline 3 & $\begin{array}{l}\text { Gley Pouco Húmico, Epieutrōfico, Alico, A moderado, textu- } \\
\text { ra média (GPH). }\end{array}$ \\
\hline 4 & $\begin{array}{l}\text { Podzólico Vermelho Amarelo Plíntico, Epieutröfico, Alico, } \\
\text { A moderado, textura barro argilo arenosa (PVA pl2). }\end{array}$ \\
\hline 5 & Brunizem Avermelhado, textura limisa $(B A)$ \\
\hline
\end{tabular}

\subsection{Aparelhos utilizados.}

Raio-X

As anālises difratométricas foram realizadas no Departamento de Geologia do Instituto de Feociēncias em São Paulo. Utilizou-se um apare Tho Rigaku fabricado pela Hitachi. A fonte de irradiação usada fori um tubo de cobre com filtro de níquel e a unidade de força operou com $35 \mathrm{kw}$ e 20 $\mathrm{mA}$. A velocidade de varredura foi de $4^{0} /$ minuto e a do papel de $2 \mathrm{~cm} /$ minuto. 
Efetuou-se a anālise microscópica em um aparelho de fabricação Carl Zeiss modelo Standard RP 48 com sistema de iluminação inserido diretamente no corpo do aparelho. 0 aumento minimo usado foi de 80 vezes e 0 máximo 800 vezes.

\subsection{Remoção de sais solūveis, matēria orgânịca, $\mathrm{MnO}_{2}$ livre e öxidos de ferro e manganēs livre.}

Amostras de $10 \mathrm{~g}$ de TFSA de cada horizonte foram colocadas em boêmias de $250 \mathrm{ml}$ e lavadas com solução de acetato de sódio a pH 5,0, pa ra remoção de sais solūveis (JACKSON, 1965). A seguir agregaram-se a esta suspensão $10 \mathrm{ml}$ de perōxido de hidrogênio a $30 \%$ para a oxidação da matéria orgānica e $\mathrm{MnO}_{2}$ livre, repetindo esta operação as vezes necessārias para a completa destruição. Fez-se nova lavagem com acetato de sódio a pH 5,0 para eliminação de sais provenientes do ataque com a āgua oxigenada.

Para a remoção dos óxidos de ferro livre, as amostras ante riormente tratadas foram transferidas para frascos de $250 \mathrm{ml}$, adicionandose $25 \mathrm{~g}$ de citrato de sódio e $2 \mathrm{~g}$ de ditionito de sódio, agitando lentamente por 16 horas em agitador horizontal. Finda esta operação, agrega-se uma solução de $\mathrm{NaCl} N$ para a floculação dos colóides, permitindo a sifonação do sobrenadante. Repetiu-se o tratamento atē as amostras apresentarem colora ção cinza ou branca.

\subsection{Dispersão e separação das diferentes frações do solo.}

A dispersão das amostras foi feita seguindo as recomendações de JACKSON (1965). A separação da fração areia total foi feita por tamisagem, usando-se um tamis com malha de 53 u de diāmetro, montado sobre funil, de maneira a receber o material com diâmetro inferior em uma proveta de 1000 ml. Neste material em suspensão, atravēs da aplicação da Lei de Stockes, se 
parou-se a fração argila total do silte. Com base na citação de MALAGOn (1975), o silte foi dividido em duas frações, uma maior que 20 u e outra me nor. A fração areia total de cada horizonte, uma vez seca em estufa a $105^{\circ} \mathrm{C}$, foi fracionada de acordo com a classificação adotada pelo USDA. Na fração dominante, denominada "moda", procedeu-se à separação dos minerais leves e pesados, utilizando bromoförmio de densidade $2.84 \mathrm{~g} / \mathrm{cm}^{3}$. 0 fracionamento foi conduzido em funis de haste longa com a adaptação de pontas de borracha, e os minerais leves e pesados foram coletados separadamente em papel de fil tro para posterior pesagem.

\subsection{Preparo e montagem das amostras}

Argila

Aliquotas da fração argila foram transferidas para tubos de centrīfuga de $100 \mathrm{ml}$ e saturadas com $\mathrm{KCl}$ e $\mathrm{MgCl}_{2}$ segundo as especificações de JACKSON (1965). De cada amostra saturadada, tomou-se aproximadamente 1 ml de suspensão de argila e transferiu-se para laaminas de vidro colocadas em superfície plana, deixando secar naturalmente, facilitando a orientação.

As lâminas saturadas com $\mathrm{K}^{+}$a $25^{\circ} \mathrm{C}$ foram levadas ao raio- $\mathrm{X}$ e irradiadas no intervalo de $3^{0}$ a $28^{\circ} 2 \theta$. Em base aos dados obtidos, selecio naram-se läminas que foram aquecidas a $350^{\circ} \mathrm{C}$ e a $550^{\circ} \mathrm{C}$ e irradiadas no mesmo intervalo, que ajudaram na identificação dos argilo-minerais. As amostras saturadas com $\mathrm{Mg}^{++}$sofreram seleção e apōs serem tratadas com etileno glicol foram irradiadas entre $3^{0}$ e $28^{0} 2 \theta$. 0 reconhecimento dos argilo-minerais foi executado em função dos espaçamentos interplanares, com base no traba Tho de WARSHAW e ROY (1963).

\section{Silte}

As amostras de silte fino $(<20 \mathrm{u})$ foram levemente umedecidas e colocadas sobre lāminas de vidro com auxīlio de uma espātula em forma de esfregaço e irradiadas num intervalo de $3^{0}$ a $60^{\circ} 2$. Para o reconhecimen to foi utilizado o trabalho de WARSHAW e ROY (1963). 


\section{Areia}

Os minera is leves e pesados da fração areia modal para cada horizonte foram separados em bromoförmio $\left(d^{\prime}=2,8 \mathrm{~g} / \mathrm{cm}^{3}\right)$. A fixação em lâmi na de vidro se fez com resina Lackside de indice de refração ccnhecido e os grânulos foram recobertos por laminnula de vidro, tendo o máxime cuidado em eliminar as bolhas de ar. 0 reconhecimento microscópico dos mirerais componentes da fração leve ou pesada, sob luz polarizada, se faz em jase as carac terísticas óticas exibidas pelo mineral. Estas caracterīsticas são prōprias de cada espécie, possibilitando assim a identificação dos mesmos.

Foram contados 200 grānulos em média, percorrendo a lâmina no sentido horizontal e vertical. A distância entre pontos adotados foi de $2 \mathrm{~mm}$, contando-se os grānulos prōximos ao retículo. Na identificação fez-se uso dos trabalhos de KERR (1950), BLOSS (1961) e PERES MATEOS (1964). 
28.

5. RESULTADOS E DISCUSSAOO

5.1. Minera logia da fração areia.

Os dados mineralógicos da fração areia estão apresentados no Quadro 3. 0 quartzo é o mineral dominante entre os minerais componentes da fração leve para todos os solos. Além do quartzo, nesta fração também ocorrem os plagioclásios calco-sōdicos, mica e microclina. Dentre os minerais pesados, além da dominância dos opacos, salienta-se tambēm a presença da mi ca, silimanita, zirconita, turmalina, estaurolita e hornblenda.

0 Latossolo Vermelho Amarelo (pedon 1) possui uma mineralo gia compativel com a sua natureza, ou seja, domināncia de minerais primários relativamente resistentes ao intemperismo, como è o caso do quartzo, zirconita e turmalina, estando coerente com os resultados encontrados por CAVALCANTI (1977) e LEPSCH (1977) para Latossolos Vermelho Escuros.

Este solo, além de ocupar a superfīcie mais atingida nesta topossequência, evoluiu a partir de sedimentos retrabalhados em avançado es tágio de intemperização (PENTEADO, 1978) justificando assim a ausência de minerais menos resistentes e que são comuns aos outros solos aqui estudados. A presença de estaurolita em percentagem relativamente elevada, sugere a 
contribuição de rochas metamörficas a estes sedimentos. Estas rochas são en contradas não só nas cabeceiras do rio São Francisco, como tambēm nas dos afluentes que compõem a bacia de seu alto curso. Outros minerais primārios de menor resistência que possam ter contaminado este sedimento jā intemperi zado, no curso de seu retrabalhamento e deposição, o tempo, como principal fator, aliado às alternāncias climáticas secas e úmidas ocorridas após o pe nĩodo deposicional e as boas condições de drenagem se encarregaram da destruição.

0 pedon 2 (PVA pll) difere na composição mineralógica do pedon 1. Neste solo, alēm dos minerais presentes no perfil anterior, nota-se a presença de mica e de alguns plagioclásios principalmente na camada mais profunda. Estes minerais conferem a este solo um caráter menos evolúido.Tal fato se deve a diversos fatores, entre os quais, a posição de ocorrência e as condições de drenagem decorrentes desta posição. Este pedon, apesar de ocupar a posição de um antigo terraço, localiza-se em uma superfície mais recente que a ocupada pelo anterior, tendo em consequência disto, menor tem po para a sua formação. O horizonte inferior, com problemas de encharcamento temporārio, vem sofrendo um decréscimo na lixiviação, reduzindo assi, a taxa de decomposição dos minerais, possivelmente pela manutenção da ativida de èlevada do $\mathrm{H}_{4} \mathrm{SiO}_{4}$ (DHANPAT RAI e LINDSAY, 1975). A ausência de minerais facilmente alterāveis (plagioclásios calco-sódicos) nas camadas superiores pode ser explicada pela ação mais intensa dos processos pedoquĩmicos de alteração (JACKSON e SHERMAM, 1953).

Os dados mineralógicos do pedon 3 (LH) mostram de maneira geral as mesmas espécies minerais que os demàis pedons jā observados, diferin do entretanto na quantidade de tais minerais, principalmente nos teores de plagioclásios, mica e a presença de hornblenda e microclina.A presença de plagioclä́sios e hornblenda ilustram o carāter pouco evolutivo deste solo. Exa minando-se a Figura 3 , nota-se que o pedon 3 ocorre numa posição deprimida sujeita a condição de encharcamento total temporārio. Os dados morfológicos têm ressaltado a condição de drenagem impedida para todos os horizontes des te solo. Nestas condições de drenagem imperfeita, com a manutenção de 'um 
30 .

ambiente mais úmido, a lixiviação è grandemente reduzida, afetando o proces so de hidrōlise, onde os minerais se intemperizam mais vagarosamente (KITTRICK, 1969). Os valores mais altos de plagioclásios calco-sódicos e horn blenda na camada superior deste pedon são decorrentes de adições realizadas por transbordamentos ocasionais do rio São Francisco.

0 pedon 4 (PVA p12) também possui uma mineralogia muito rica em minerais primários facilmente intemperizáveis, como principalmente plagio clásios e hornblenda, o que vem evidenciar o carāter pouco evolutivo deste solo. A ocorrência destes minerais estā aliada, além das condições anterior mente descritas para o pedon 3 , porém menos severas, a um perỉodo deposicio nal mais recente dos sedimentos que lhe deram origem, acarretando um menor tempo de evolução.

Ocorrendo nas proximidades do rio São Francisco, o pedon 5 tem recebido grande contribuição deste rio em sua mineralogia. Os dados apre sentados no Quadro 3 ilustram tal fato. As quantidades de plagioclásios, mi ca e hornblenda são realmente muito elevadas quando comparadas com os demais solos. As condições de drenagem são excelentes, não havendo qualquer impedimento, como descrito no exame morfológico.

A ocorrência deste percentual elevado de minerais facilmente decomponiveis no pedon 5 (BA) estā associado, não só a um perỉodo deposició nal recente dos sedimentos, resultando em menor tempo de exposição aos processos de alteração, mas também, às condições climáticas, pois segundo $P E N-$ TEADO (1972), o clima passado foi mais seco que o atual, não havendo portan to condições para o estabelecimento de processos pedoquímicos de dissolução, por insuficiēncia de água pedologicamente ariva no sistema. A evolução climática evidenciada na atualidade por um cl ima sub-ümido (Quadro 1), tem facul tado a alteração destes minerais, verificado no Quadro 3 , pela diminui ção dos plagioclásios calco-sódicos nas camadas superficiais. 
Quadro 3 - Anālise mineralógiça da fração areia em porcentagem de ocorrência de minerais.

\begin{tabular}{|c|c|c|c|c|c|c|c|c|c|}
\hline \multirow{3}{*}{$\begin{array}{l}\text { Minerais } \\
\text { Pesados }\end{array}$} & \multicolumn{8}{|c|}{ Pedon 1} & \multirow{3}{*}{$\begin{array}{l}\text { Minerais } \\
\text { Leves }\end{array}$} \\
\hline & \multicolumn{4}{|c|}{ Horizontes } & \multicolumn{4}{|c|}{ Horizontes } & \\
\hline & Al & Bs & $q 1$ & Bsq2 & A1 & & Bsql & Bsq2 & \\
\hline Opacos & 71 & & 71 & 79 & 100 & & 100 & 99 & Quartzo \\
\hline Turmalina & 5 & & 5 & 5 & - & & - & 1 & Mica \\
\hline Zirconita & 3 & & 3 & 1 & & & & & \\
\hline \multirow[t]{3}{*}{ Estaurolita } & 11 & & 16 & 14 & & & & & \\
\hline & \multicolumn{8}{|c|}{ Pedon 2} & \\
\hline & Al & $\mathrm{Btl}$ & Bt2 & $\mathrm{Cpn}$ & A1 & Btl & Bsq2 & Cnp. & \\
\hline Opacos & 88 & 89 & 88 & 86 & 99 & 99 & 99 & 93 & Quartzo \\
\hline Turmalina & - & - & 1 & 4 & 1 & 1 & 1 & 3 & Mica \\
\hline Zirconita & 2 & - & - & - & - & - & - & 4 & Plagioclāsic \\
\hline Silimanita. & 2 & 5 & 3 & - & & & & & \\
\hline Mica & 4 & 4 & 5 & 6 & & & & & \\
\hline \multirow[t]{3}{*}{ Outros } & 2 & 2 & 3 & 4 & & & & & \\
\hline & \multicolumn{8}{|c|}{ Pedon 3} & \\
\hline & A1 & $B t 7$ & Bt2 & $\mathrm{Cpn}$ & Al & $\mathrm{Bt} 7$ & Bt2 & Cpn & \\
\hline Opacos & 53 & 58 & 48 & 49 & 80 & 80 & 82 & 84 & Quartzo \\
\hline Turmal ina & 7 & 6 & 9 & 4 & 2 & 1 & 2 & 1 & Mica \\
\hline Zirconita & 5 & 7 & 4 & 7 & 15 & 12 & 13 & 11 & Plagioclāsio \\
\hline Silimanita & 2 & 3 & 4 & 2 & 2 & 3 & 3 & 3 & Microclina \\
\hline Estaurolita & 2 & 3 & 6 & 7 & 1 & 4 & - & - & Outros \\
\hline Hornblenda & 5 & 1 & 4 & 7 & & & & & \\
\hline Mica & 14 & 20 & 21 & 20 & & & & & \\
\hline Outros & 2 & 2 & 2 & 1 & & & & & \\
\hline (Continua) & & & & & & & & & \\
\hline
\end{tabular}


Quadro 3 - Continuação.

\begin{tabular}{|c|c|c|c|c|c|c|c|c|c|c|c|}
\hline \multirow{3}{*}{$\begin{array}{l}\text { Minerais } \\
\text { Pesados }\end{array}$} & \multicolumn{10}{|c|}{ Pedon 4} & \multirow{3}{*}{$\begin{array}{l}\text { Minera is } \\
\text { Leves }\end{array}$} \\
\hline & \multicolumn{5}{|c|}{ Horizontes } & \multicolumn{5}{|c|}{ Horizontes } & \\
\hline & Al & $B / A$ & Btpn2 & $2 C 3$ & 3Cpn & A.1 & $B / A$ & Btpn2 & $2 C$ & $3 \mathrm{Cpn}$ & \\
\hline Opacos & 54 & 70 & 56 & 55 & 56 & 82 & 81 & 86 & 86 & 86 & Quartzo \\
\hline Turmalina & 10 & 4 & 11 & 6 & 6 & 1 & 3 & - & - & $=$ & Mica \\
\hline Zirconita & - & - & 2 & 7 & 3 & 14 & 16 & 12 & 13 & 18 & Plagioclāsio \\
\hline Silimanita & 3 & 1 & 5 & 4 & 2 & 3 & - & 1 & - & 2 & Microclina \\
\hline Es taurol ita & 5 & 5 & 1 & 1 & 2 & - & - & - & - & - & Outros \\
\hline Hornblenda & 5 & 5 & 3 & 3 & 3 & & & & & & \\
\hline Mica & 20 & 14 & 19 & 21 & 23 & & & & & & \\
\hline \multirow[t]{3}{*}{ Outros } & - & $\infty$ & 3 & 1 & 4 & & & & & & \\
\hline & \multicolumn{10}{|c|}{ Pedon 5} & \\
\hline & Al & A2 & $B t 1$ & Bt2 & $2 C$ & $A 1$ & A2 & $B$ t 1 & Bt2 & $2 C$ & \\
\hline Opacos & 62 & 71 & 72 & 59 & 54 & 89 & 83 & 83 & 83 & 79 & Quartzo \\
\hline Turmalina & 3 & 2 & 1 & 2 & 3 & 5 & 4 & 2 & 1 & 1 & Mica \\
\hline Zirconita & 4 & 3 & 2 & 2 & 3 & 6 & 8 & 12 & 14 & 16 & Plagioclāsio \\
\hline Silimanita & - & 2 & 2 & 1 & 1 & - & 3 & 2 & - & 3 & Microclina \\
\hline Estaurolita & 3 & 2 & 1 & 2 & 3 & - & 2 & 1 & 2 & 1 & Outros \\
\hline Hornblenda & 6 & 6 & 2 & 12 & 9 & & & & & & \\
\hline Mica & 25 & 10 & 15 & 20 & 25 & & & & & & \\
\hline Outros & 3 & 2 & 3 & 2 & 2 & & & & & & \\
\hline
\end{tabular}


Os sedimentos que deram origem aos diferentes soios encon trados nesta topossequencia pertencem ao retrabalhamento imposto pelo rio São Francisco. A diversificação em minerais primārios, decomponíveis ou não, tem suas origens nas diferentes formações rochosas (MATTOS e PEREIRA DA CUNHA, 1977 e PONÇANO e PAIVA, 1972) encontradas na rede hidrogräfica que compõe 0 alto curso deste rio, as quais cederam minerais à composição destes sedimentos (Figura 4 ).

A medida que se distancia do referido rio, a porcentagem média de minerais facilmente decomponiveis, obtida pela soma de hornblenda e plagioclásiós, diminui, chegando a desaparecer completamente na posição ocu pada pelo pedon 1. Realça nesta topossequência a deposição mais recente dos sedimentos na planície aluvial para os pedons 3,4 e 5 , quando comparados com 1 e 2, destacando-se o tempo como agente de decomposição dos minerais e formador dos solos.

A Figura 5 mostra a colocação dos pedons em relação ao rio em função da porcentagem média de hornblenda e plagioclásio.

\subsection{Mineralogia da fração silte fino deferrado $(2-20 \mathrm{u})$}

Dos minerais primārios anteriormente diagnosticados na fração areia dos pedons estudados, o quartzo, mica e pequenas proporções de feldspatos são facîlmente identificāveis na fração silte atravēs da difração dos raios $X$.

A caulinita como mineral secundārio è comum a todos os solos, podendo a sua ocorrência estar relacionada como herança do material origi nal, ou ser produto da alteração dos minerais primārios, feldspatos e micas. Esta mesma explicação se estende aos minerais secundārios de grade 2:1 e in terestratificados que ocorrem nos pedons 3,4 e 5 . 
34.

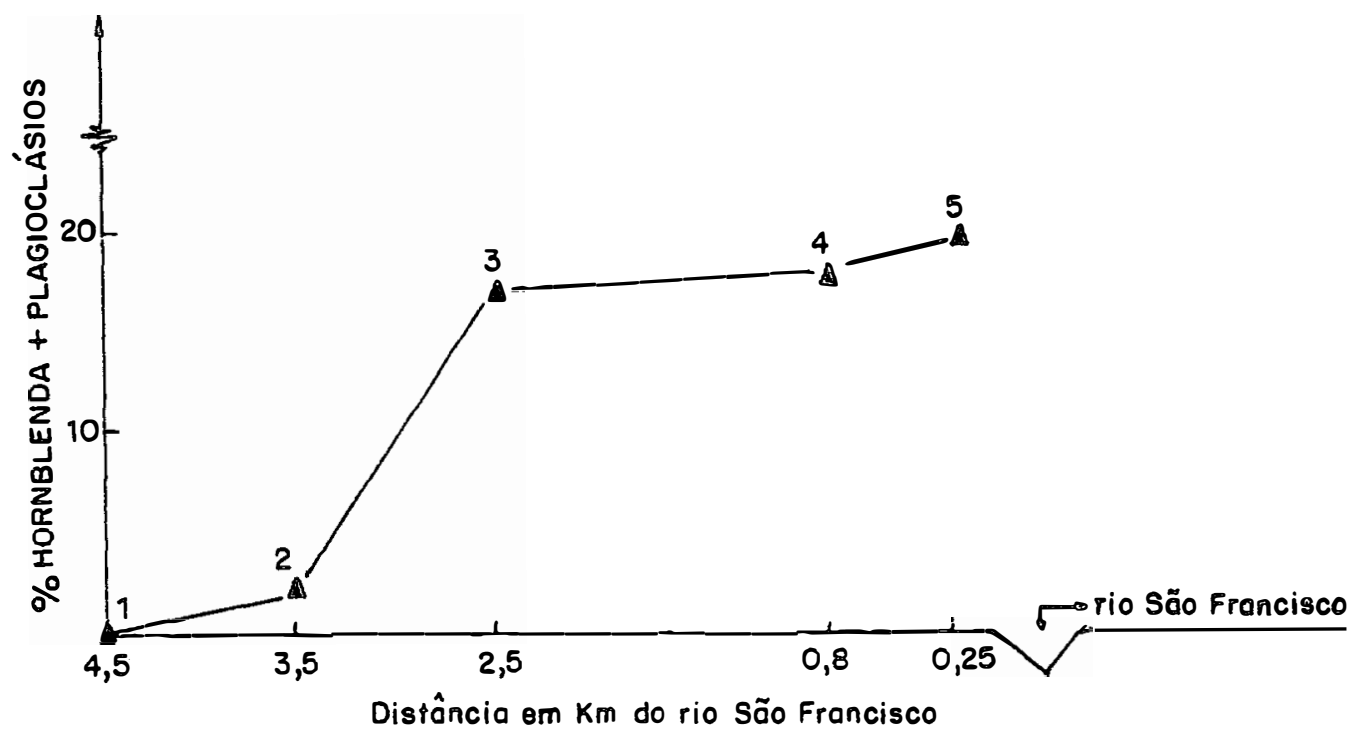

Figura 5 - Porcentagem de hornblenda + plagioclāsios dos pedons em relação à distāncia do rio São Francisco. 
35.

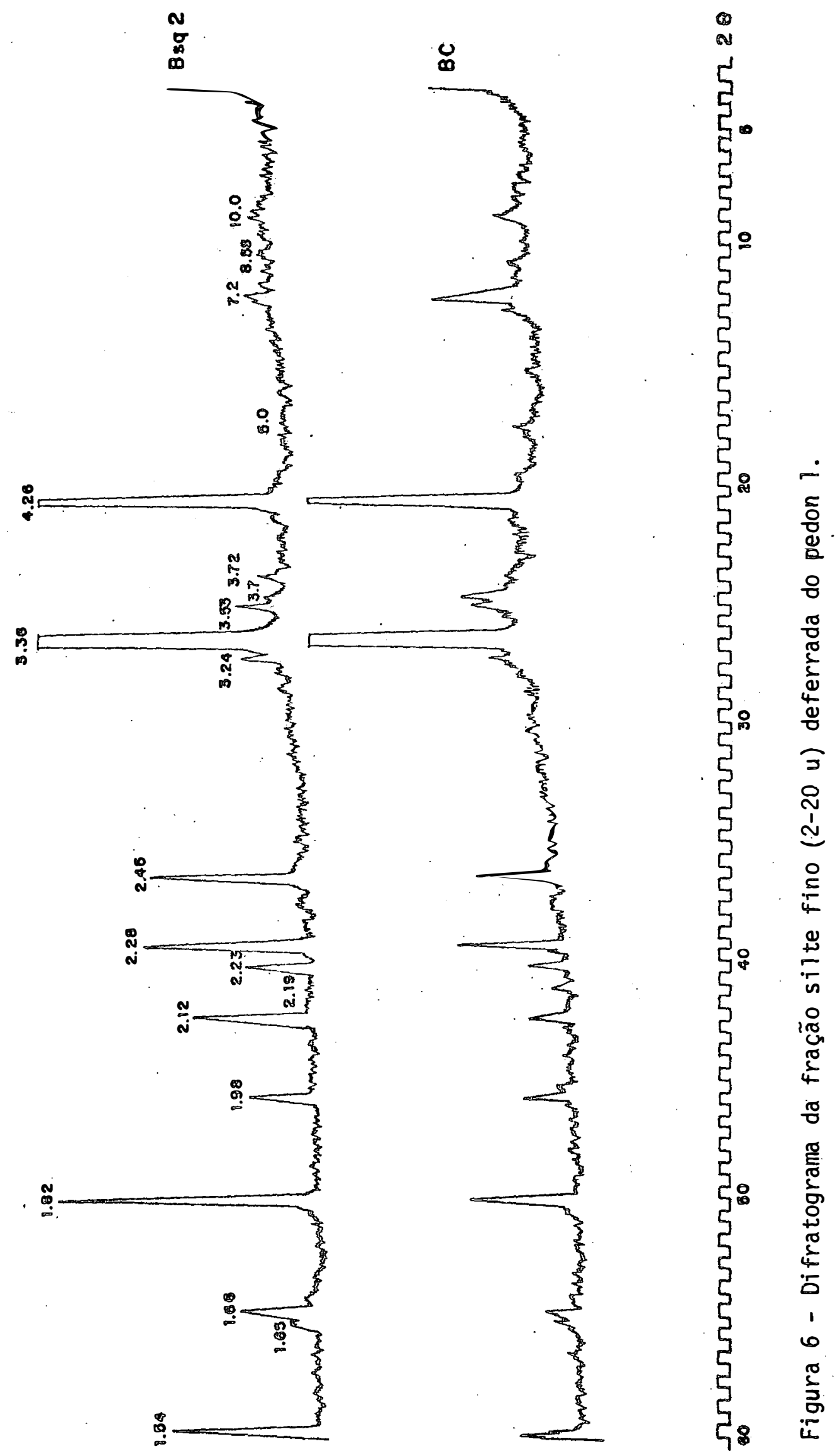


0 pedon 1 (LVA) tem os seus resultados mineralógicos expressos na Figura 6. A dominância de quartzo é evidenciada pela intensidade relativa dos picos $(4,26 \AA$ e $3,36 \AA)$, nas camadas analisadas. Os horizontes superiores deste solo não foram analisados devido à pequena quantidade de material na fração entre 2-20 u.

A intensidade e nitidez do pico da culinita aumentam do horip zonte Bsq2 ao BC sugerindo provāveis hipōteses para tal acontecimento. 0 au mento em profundidade pode estar associado à sua presença no material de ori gem, uma vez que estes sedimentos são retrabalhados. Os valores menores no horizonte Bsq2 poderiam estar ligados à transformação deste mineral em um ou tro, hipótese esta descartada pela ausência de gibbsita. Uma outra explica ção seria que a caulinita estā sendo formada a partir da alteração de mine rais como mica e feldspato, justificando assim os picos mal definidos devido a um baixo grau de cristalinidade (MONIZ et alii, 1976). Pequenos picos a $10 \AA$ e a $3,24 \AA$ mostram a ocorrência de mica e feldspato nesta fração.

Em um estágio de evolução pouco menor o pedon 2 (PVApll) (Figu ra 7), difere do anterior pela presença de minerais interestratificados a $11,6 \AA$ e de feldspatos que desaparecem na camada superficial possivelmente devido a sua alteração. Para o pedon $3(H)$, comparativamente os teores relativos de mica ( $10 \AA)$ e caul inita são maiores nas camadas superficiais,demons trando uma ação intempérica mais ativa sobre os minerais primārios transformando-0s em argilas (Figura 8). Estes horizontes estão sujeitos a períodos úmidos prolongados, facilitando a transformação de vermiculita $(14,24 \AA)$, in terestratificados $(12,26 \AA)$, mica $(10 \AA)$ e caulinita $(7,2 \AA)$. A situação do pedon no relevo condiciona- -1 he uma drenagem imperfeita, permitindo a perma nência das bases, sîlica e alumínio indispensāveis à sîntese dos minerais (KITROCK, 1969)。

0 pedon 4(PVAp12)é bastante rico em mica(10尺) e caulinita (7ij24 A) fato este verificado pela intensidade dos picos apresentados na Figura 9. Comparativamente os horizontes $\mathrm{Al}$ e Btl são bastante similares em conteúdo 


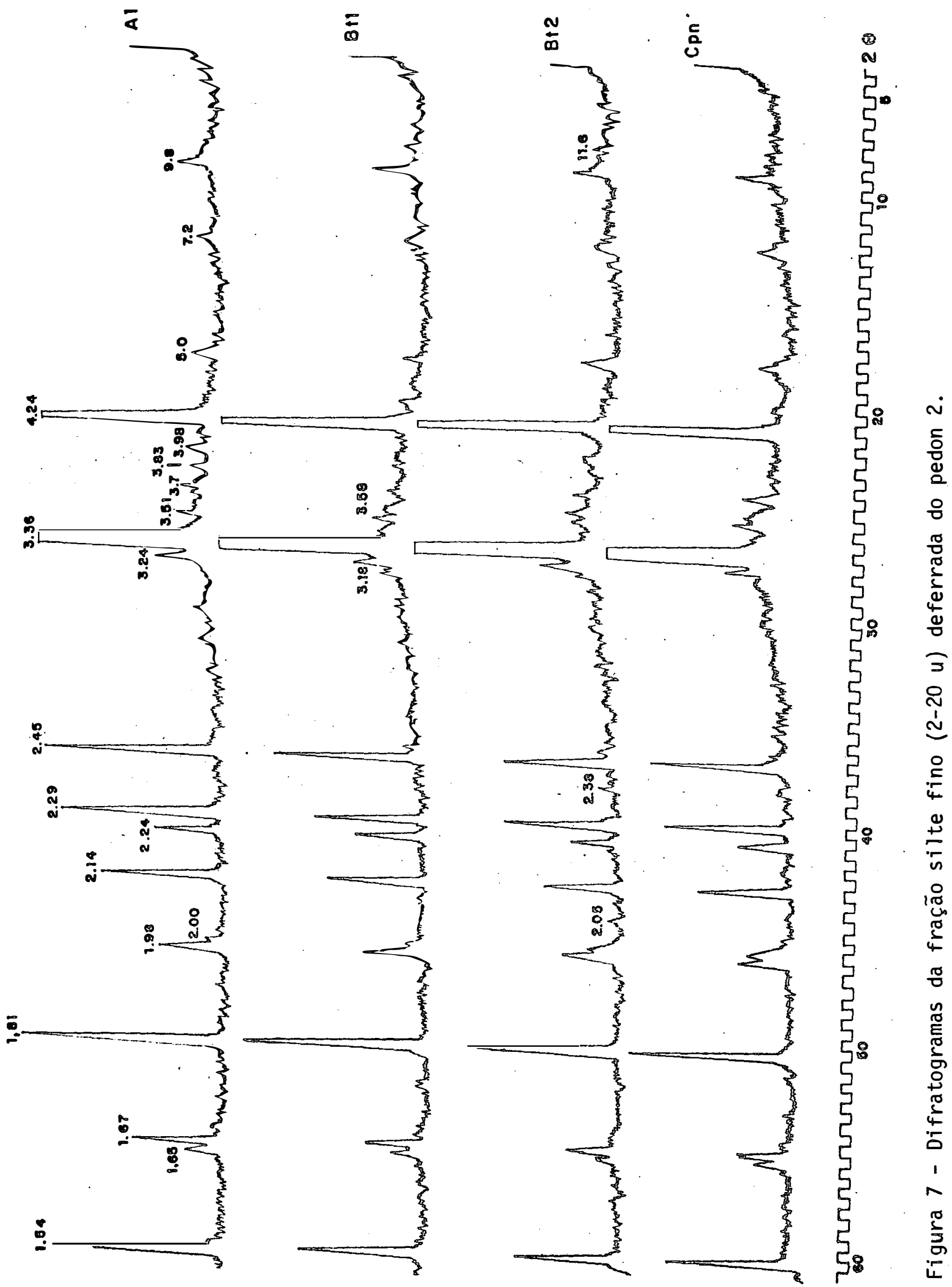




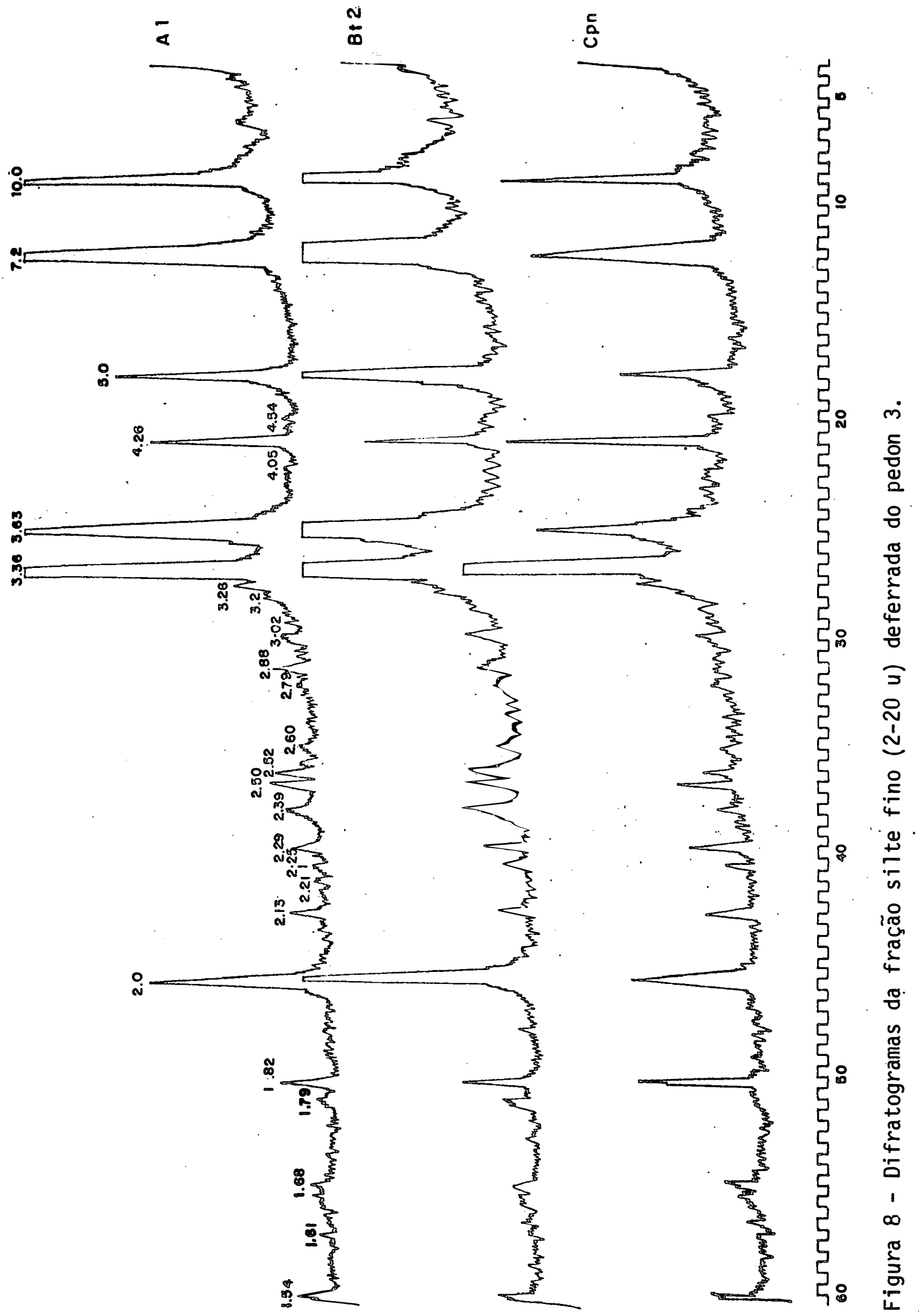




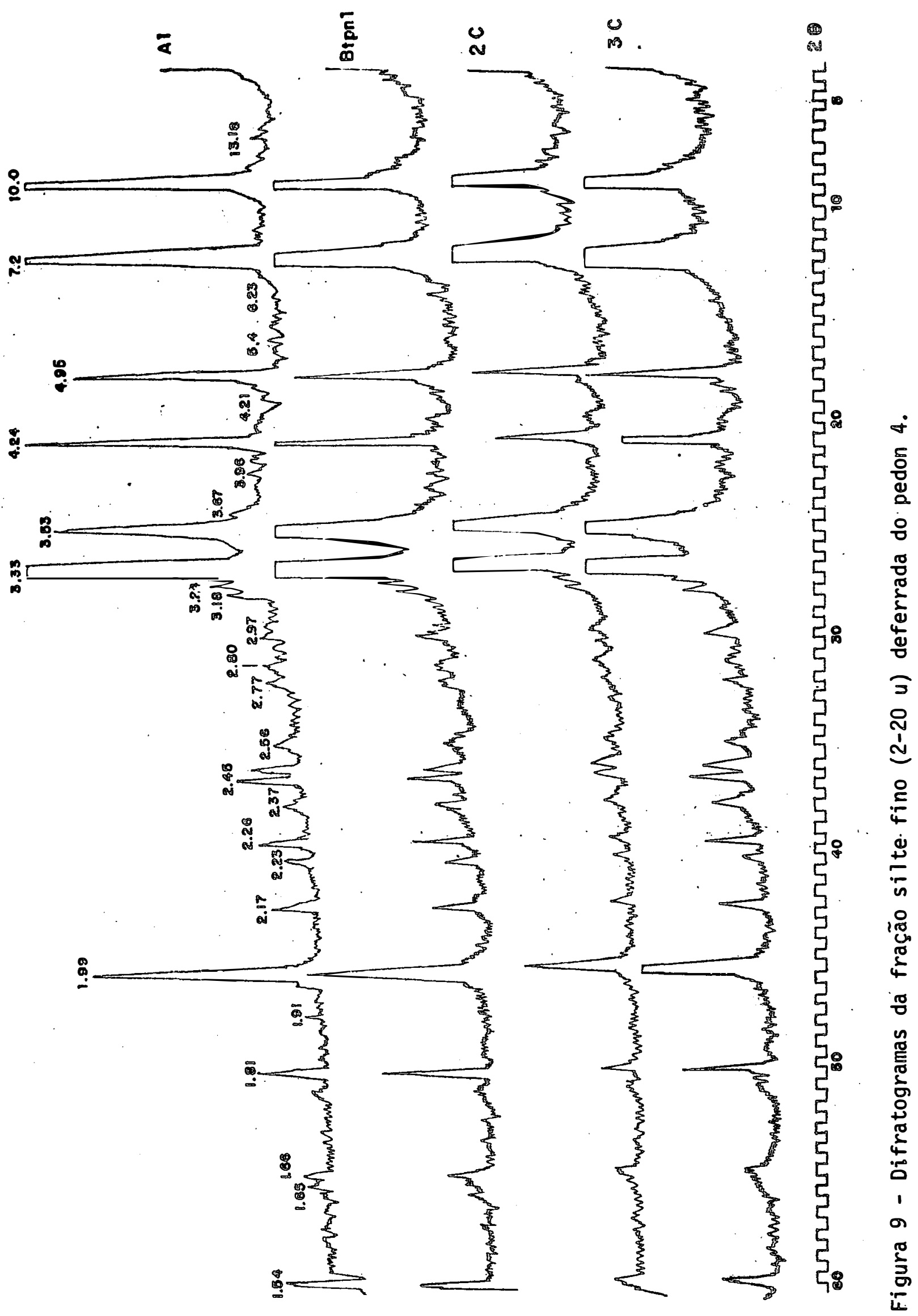


de minerais primărios e secundários nesta fração. As demais camadas fazem parte de uma série de descontinuidades litológicas, dificul tando uma anālise comparativa.

Para o pedon 5 (BA), ecluindo o ūl timo horizonte, por não fa zer um contínuo com os demais, pode-se dizer que a camada superficial vem sofrendo as maiores transformações em sua mineralogia. A intensidade dos $\mathrm{p} i$ cos, principalmente da caulinita $(7,2 \AA)$, quando comparado com o horizonte Btl dá essa idéia. Os minerais argilosos encontrados são o reflexo do processo de intemperização sobre os minerais primários facilmente decomponíve is, abundantes neste pedon que, apesar de bem drenado, mantém as condições para a formação de vermiculita $(14,24 \AA)$, interestratificados (mica-vermiculita $11 \AA)$ e mica $(10 \AA)$, devidó, talvez à liberação constante dos elementos necessārios atravēs da dissolução dos minerais primários. Os resultados da anālise da fração silte fino para este pedon encontram-se na figura 10.

0 intemperismo químico pode ser acelerado pela ação dos processos físicos de decomposição, que promovem a subdivisão dos minerais, aumentando a superfície específica, levando-os a tamanhos mínimos, onde a estabilidade não pode ser mantida (JACKSON, 1948) citado por JACKSON e SHERMAN (1953). Para as condições estudadas, os processos físicos atuaram durante 0 transporte e deposição dos sedimentos. A ação atual é praticamente nula, fi cando o intemperismo a cargo dos processos químicos ande a hidrōlise desempenha papel fundamental. Suas ações vêm sendo freadas principalmente pelas condições do clima passado e atual, possibilitando a ocorrência de minerais de fácil alteração nas frações silte fino e areia.

\subsection{Mineralogia da fração argila deferrada.}

Nesta topossequência, independente do estāgio de evolução apre sentado pelos solos ou posição fisiogrāfica ocupada, a caulinita $(7,2 \AA)$ ē 0 mineral de argila dominante, contribuindo com mais de $50 \%$ na composição mineralógica dos cinco pedons estudados (Quadro 4). Em proporções menores a 


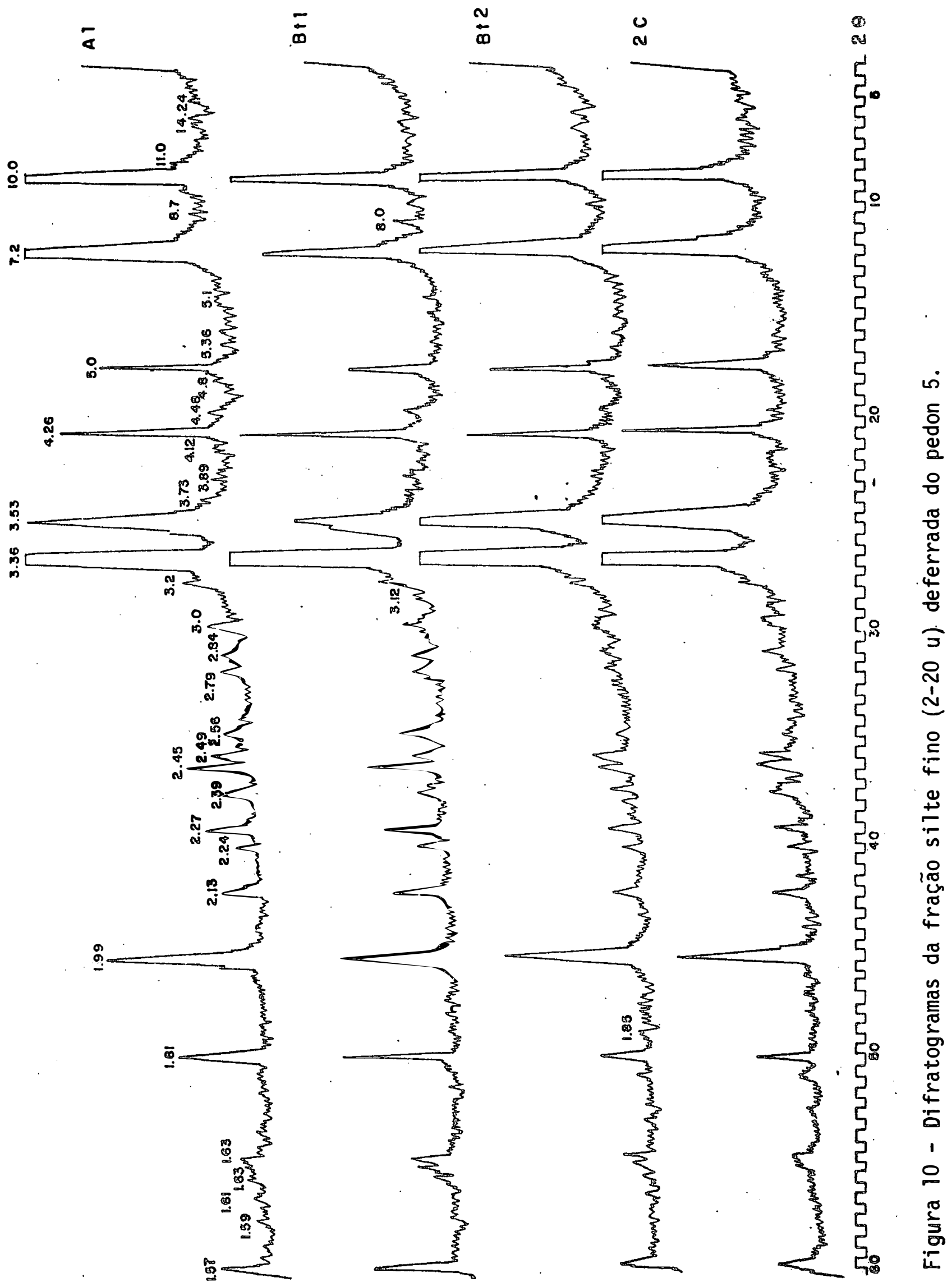


mica (10 凡) é o segundo mineral em importāncia de ocorrência, variando ampla mente os seus valores relativos.

Quadro 4 - Composição mineralógica e semi-quantitativa dos minerais da fração argila dos solos estudados.

\begin{tabular}{|c|c|c|}
\hline Pedon & Horizontes & Minera is* \\
\hline \multirow[t]{4}{*}{1} & Al & C3, Mit, It \\
\hline & Bsql & C3, Mit, It \\
\hline & Bsq2 & C3, Mit, It \\
\hline & $B / C$ & C3, Mit, It \\
\hline \multirow[t]{4}{*}{2} & Al & $\mathrm{C} 3, \mathrm{Mi2}$, It \\
\hline & Btl & $\mathrm{C} 3, \mathrm{Mi}, \mathrm{I}, \mathrm{It}$ \\
\hline & Bt2 & $\mathrm{C} 3, \mathrm{Mi}, \mathrm{It}, \mathrm{CLt}$ \\
\hline & Cpn & $\mathrm{C} 3, \mathrm{Mil}, \mathrm{It}, \mathrm{CLt}$ \\
\hline \multirow[t]{4}{*}{3} & Al & $\mathrm{C} 3, \mathrm{Mi2}, \mathrm{It}, \mathrm{CL} t, \mathrm{Vt}, \mathrm{Mt}$ \\
\hline & Btl & $\mathrm{C} 3, \mathrm{Mi2}, \mathrm{It}, \mathrm{CL} t, \mathrm{Vt}, \mathrm{Mt}$ \\
\hline & Bt2 & $\mathrm{C} 3, \mathrm{Mil}, \mathrm{It}, \mathrm{CL}], \mathrm{Vt}, \mathrm{Mt}$ \\
\hline & $2 \mathrm{Cpn}$ & C3, Mil, It, CLl, Vt, Mt \\
\hline \multirow[t]{6}{*}{4} & $A 1$ & $\mathrm{C} 3, \mathrm{Mi} 2, \mathrm{It}, \mathrm{CL} t, \mathrm{Vt}, \mathrm{Mt}$ \\
\hline & $B / A$ & $\mathrm{C} 3, \mathrm{Mi2}, \mathrm{It}, \mathrm{CL} t, \mathrm{Vt}, \mathrm{Mt}$ \\
\hline & Btl & $\mathrm{C} 3, \mathrm{Mil}, \mathrm{It}, \mathrm{CL} t, \mathrm{Vt}, \mathrm{Mt}$ \\
\hline & Btpn2 & $\mathrm{C} 3, \mathrm{Mil}, \mathrm{It}, \mathrm{CLt}, \mathrm{Vt}, \mathrm{Mt}$ \\
\hline & $2 C$ & $\mathrm{C} 3, \mathrm{Mi} 1, \mathrm{It}, \mathrm{CLt}, \mathrm{Vt}, \mathrm{Mt}$ \\
\hline & $3 \mathrm{cpn}$ & $\mathrm{C} 3, \mathrm{Mi} 2, \mathrm{It}, \mathrm{CL} t, \mathrm{Vt}, \mathrm{Mt}$ \\
\hline \multirow[t]{5}{*}{5} & $A 1$ & $\mathrm{C} 3, \mathrm{Mi} 2, \mathrm{It}, \mathrm{Vt}, \mathrm{Mt}$ \\
\hline & A2 & $\mathrm{C} 3, \mathrm{Mi} 2, \mathrm{It}, \mathrm{Vt}, \mathrm{Mt}$ \\
\hline & Btl & $\mathrm{C} 3, \mathrm{Mi2}, \mathrm{It}, \mathrm{Vt}, \mathrm{Mt}$ \\
\hline & Bt2 & $\mathrm{C} 3, \mathrm{Mi} 2, \mathrm{It}, \mathrm{Vt}, \mathrm{Mt}$ \\
\hline & $2 C$ & $\mathrm{C} 3, \mathrm{Mi2}, \mathrm{It}, \mathrm{Vt}, \mathrm{Mt}$ \\
\hline
\end{tabular}

*C = caulinita, $M i=$ mica, $I=$ interestratificados, $C L=$ clorita, $V=$ vermiculita, $M=$ montmorilonita. Os nümeros indicam quantidades relativas em função de intensidade dos picos de raios $x t=\operatorname{traços;~} 1=10-20 \%, 2=$ $20-50 \%$ e $3 \Rightarrow>50 \%$. 
Os minerais interestratificados (vermiculita cloritizada, mica-vermiculita) ocorrem em proporções menores que $10 \%$ em todos os pedons . Is to sugere que na evolução destes sedimentos aos solos atuais, a transfonma ção da mica em caulinita tenha um estágio intermediārio de minerais interestratificados. JACKSON (1964), refere-se à formação destes minerais em condi ções tropicais, devido à deposição de hidrōxidos de alumīnio polimerizados nos espaços interlaminares das vermicul jtas e montmorilonitas, tornando-os relativamente estāveis.

Os conteúdos elevados de caulinita e mica podem ser explicados pela diversificada composição mineralógica das frações mais grosseiras analisadas, como produto de al teração destes minerais primários e também por herança do substrato de origem, que tem em sua composição materiais perten centes à bacia fornecedora do alto curso do rio São Francisco. A ocorrência de clorita nos pedons 2,3 e 4 provavelmente foi herdada do sedimento de origem destes solos, ou formada "in situ" pela alteração da mica ou hornblen da (STEPHEN, 1952b).

0 tempo de deposição dos sedimentos aumenta à medida que a distância em relação ao rio se torna maior. Assim, o processo de intemperismo atuou até,o momento diferentemente sobre estes minerais, condicionando um aumento de minerais de grade $2: 1$ à medida que a proximidade ao rio se faz maior (pedons 4 e 5 ) comparados com os pedons 1 e 2 .

No pedon 1 a caulinita é o mineral dominante com mais de $50 \%$, sendo identificada pelos picos de $7,2 \AA$ em amostras saturađas com pọtássio a $25^{\circ} \mathrm{C}$, desaparecendo quando aquecida a $550^{\circ} \mathrm{C}$. Este mineral ocorre juntamente com a mica $(10-20 \%)$ reconhecida pela permanência do pico de $10 \AA$ independente do tratamento sofrido pela amostra. 0 bandeamento dos picos entre $10 \AA$ e $14 \AA$, na amostra saturada com potássio, indica a presença de minerais interestratificados de grade 2:1 (Figuras 11 e 12). 


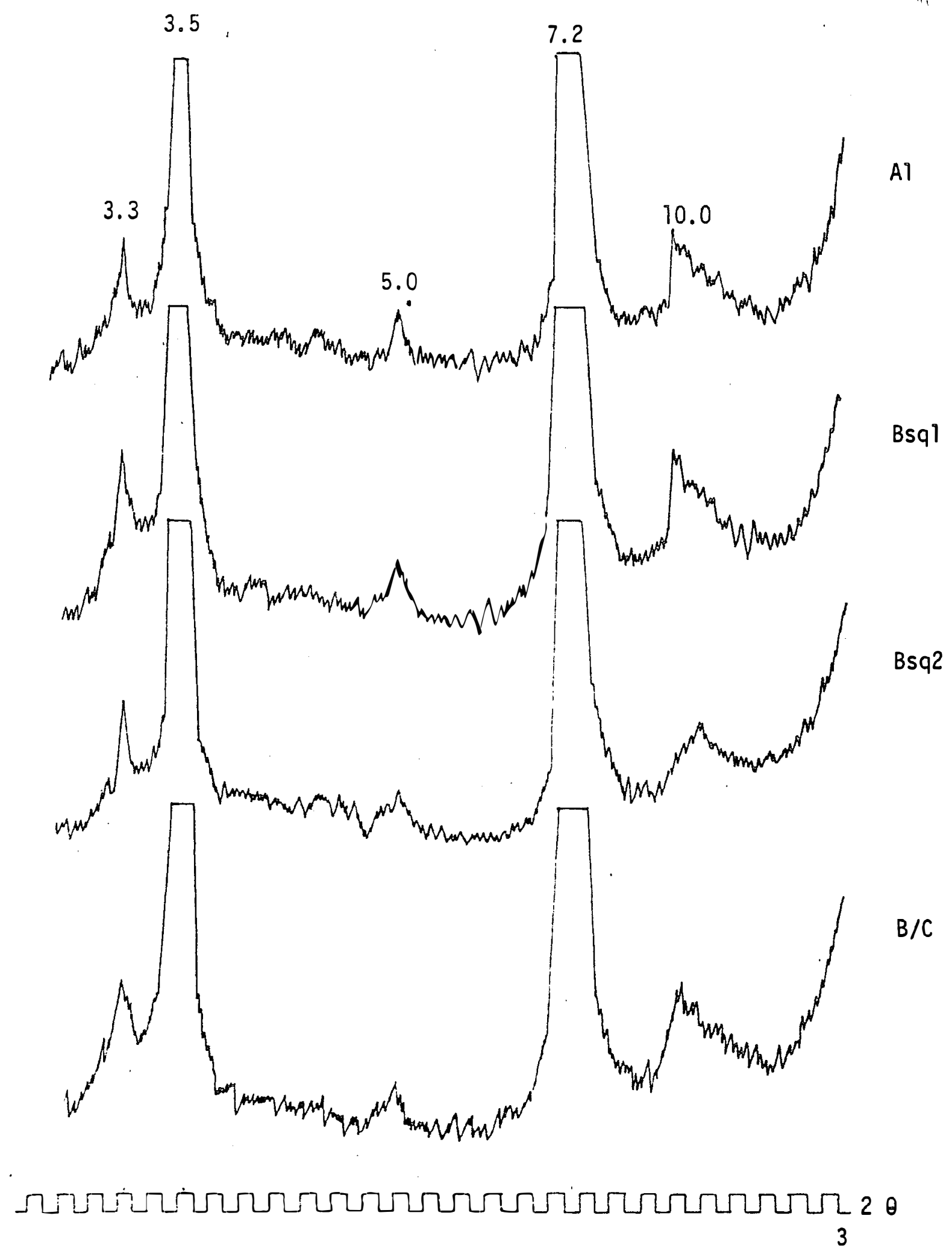

Figura 11 - Difratogramas da fração argila (<2 u) deferrada do pedon 1. 

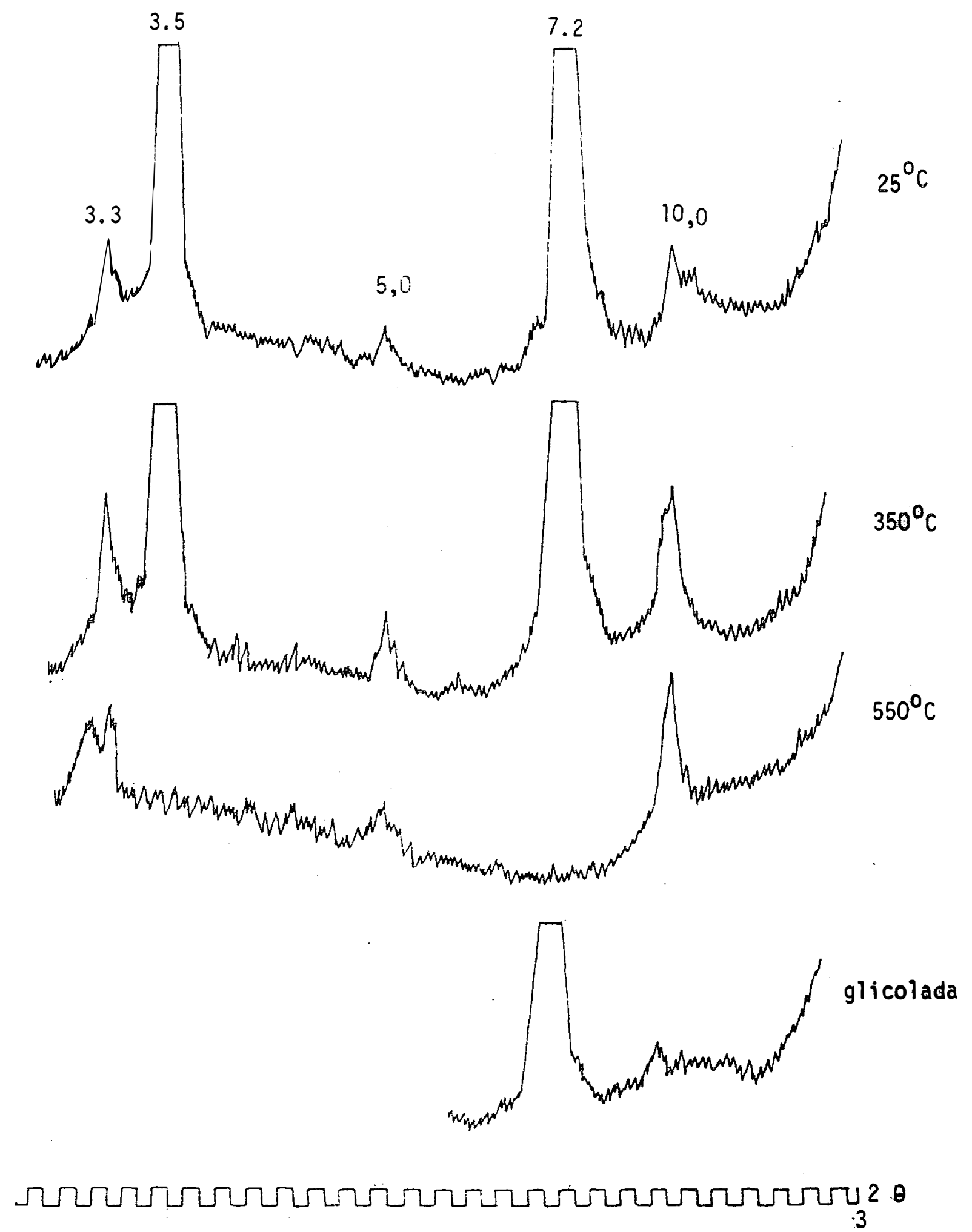

Figura 12 - Difratogramas da fração argila $(<2 u)$ deferrada do horizonte $B$ do pedon 1. 
Apesar deste solo ocupar a posição mais antiga na paisagem, a ausência de gibbsita deve-se provavelmente à capacidade deste solo em man ter a atividade de $\mathrm{H}_{4} \mathrm{SiO}_{4}$ em solução, fora do campo de estabil dade deste mineral. Estes resultados concordam com os obtidos por LEPSCE =. et alii 1977a) para os solos das superfícies mais antigas do planalto c.e Echaporã.

A caulinita è encontrada juntamente com a mica em teor'es bastante baixos na fração 2 a $20 \mathrm{u}$, não sendo notada a presença de outros mine rais $2: 1$ e 2:2. Na fração argila há um pequeno acréscimo nos välores de mica e dos interestratificados, sendo que a caulinita passa a ser o mineral dominante. Isto sugere a herança do material parental ou a sintese deste mi neral a partir da mica, passando por um estágio intermediārio entre mica-ver miculita ou vermiculita cloritizada, sendo que os seus valores relativos mos tram a tendência de aumentar em profundidade (Figuras 11 e 12). A monossialitização (MELFI e PEDRO, 1977) ou dissilicatização moderada (JACKSON, 1964) pode ser induzida pelo aumento da concentração de $\mathrm{SiO}_{2}$ promovido pela presen ça de quartzo, fazendo regredir a hidrōlise dos aluminossilicatos, modifi cando o tipo de alteração. FAUCK (1920), em citação de MELFI e PEDRO (1977), mostra que o quartzo chega a impedir que a alitização se desenvolva.

Os difratogramas de raios $x$, apresentados nas figuras 13 e 14 , mostram para o pedon 2 a composição mineralögica da sua fração argila $(<2 u)$. A caulinita é o mineral dominante em todo o pedon, seguido por mica, interes tratificados e traços de clorita, restrita às camadas mais profundas deste pedon. Os teores relativos de caulinita podem ser considerados constantes em todas as camadas, exceção feita para o horizonte $\mathrm{Cpn}$, onde seu valor diminui. As condições de drenagem imperfeita deste horizonte facultam a formação de minerais menos intemperizados.

A intensidade dos picos de mica $(10 \AA)$ conduz a valores relati vos de $20^{\circ}$ a $50 \%$ deste mineral no horizonte $A$ para 10 a $20 \%$ nos horizontes inferiores a ele. 0 aumento de mica em superfície pode ser explicado pela transformação de minerais primārios das frações mais grosseiras, como pode ser verificado no Quadro 3 e pelo desaparecimento do pico de 3,18 \& na fra- 


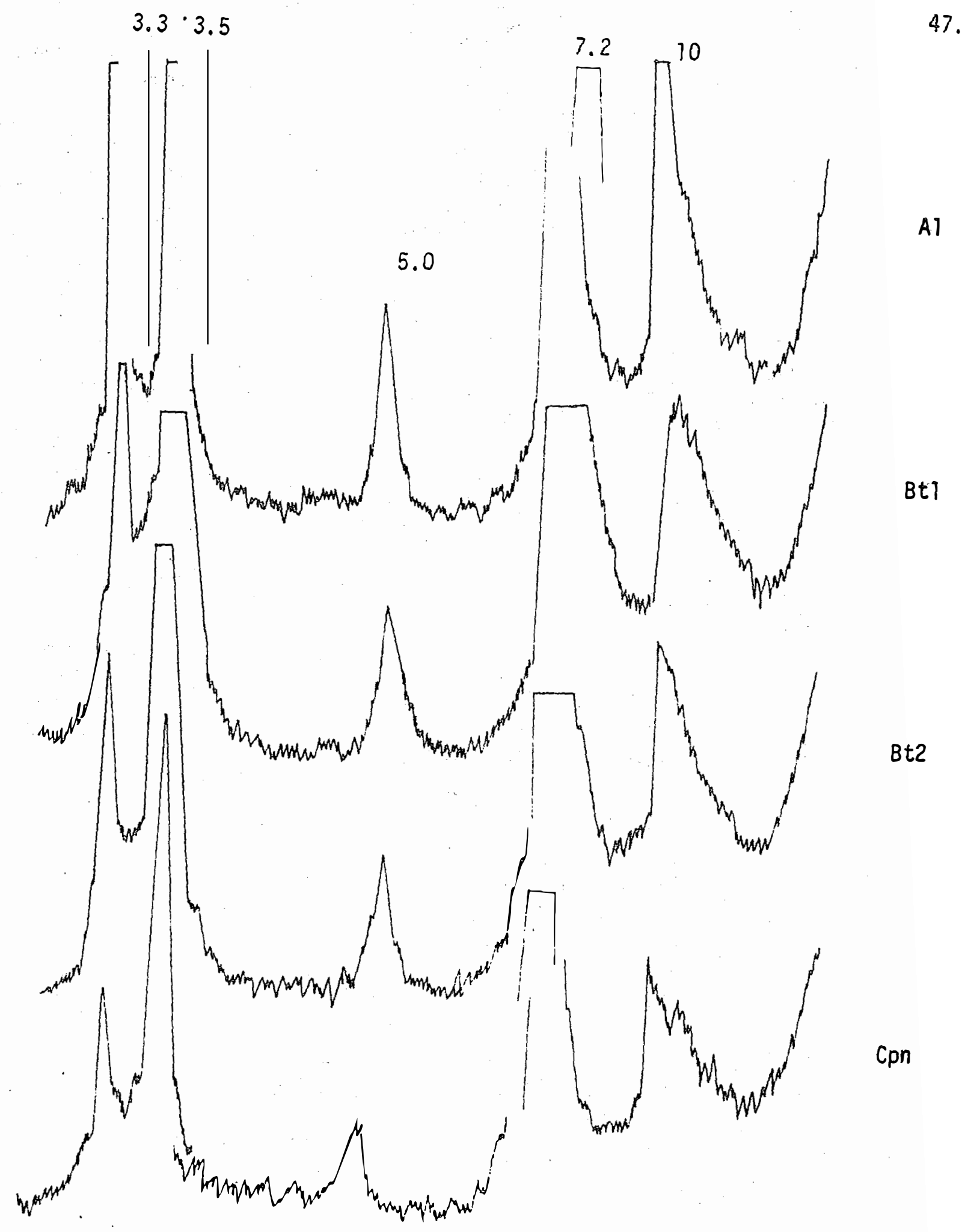

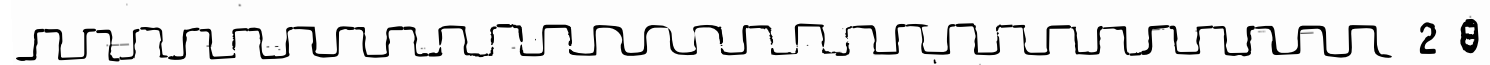

Figura 13 - Difratogramas da fração argila $(<2 u)$ deferrada do pedon 2. 


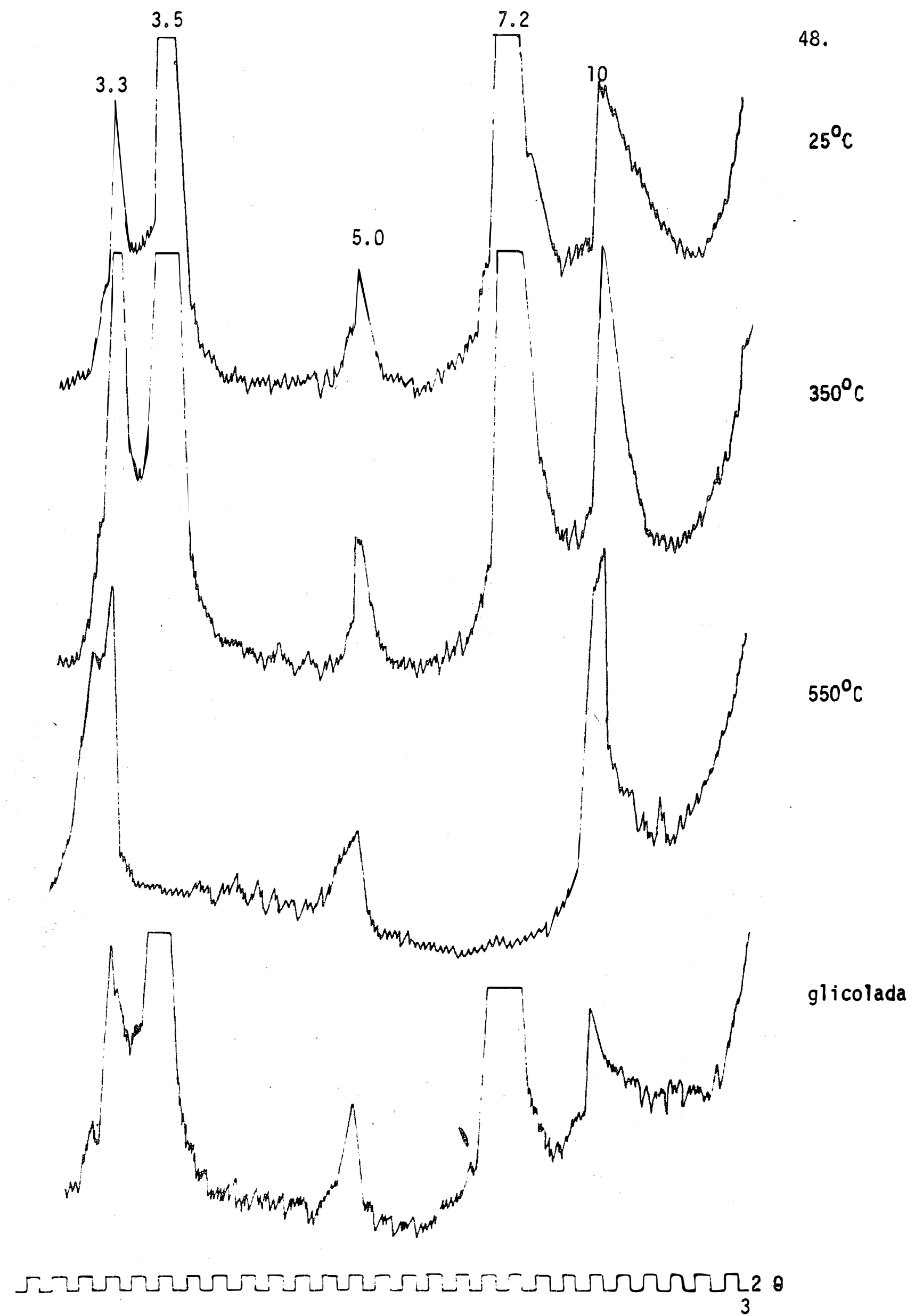

Figura 14 - Difratograma da fração argila $(<2$ u) deferrada do horizonte $B$ do pedon 2. 
49.

ção entre 2-20 u do horizonte $A$, com neoformação deste tipo de argila. Ainda comparando as frações de 2 a 20 u e menor que 2 u, os teores de caulinita e mica são praticamente desprezíveis na primeira, sofrendo um grande aumento na fração $2 \mathrm{u}$, sugerindo mais uma vez a transformação dos feldspa tos $(3,18 \AA$ e $3,24 \AA)$, a caulinita passando por uma fase intermediária de minerais de grade $2: 1$ e 2:2.

A Figura 15 mostra o difratograma de raios $X$ para 0 pedon 3 em profundidade. A anālise revela que os valores estimados de caulinita são superiores a $50 \%$, decrescendo no horizonte Cpn. A razão des te decréscimo $j \bar{a}$ foi considerada na discussão do perfil anterior. Os teores de mica (10 $\AA$ ) aumentam nos horizontes $A$ e Btl, quando em comparação com os demais, como ocorre para o pedon 2.

A intensidade dos picos a $14 \AA$ aumenta das camadas inferiores para a superior, evidenciando que a ação intempérica mais forte em superfície:. sobre os minerais primārios das frações maiores que 2 u, deve estar associada à permanência dos produtos de solubilização dos minerais nesta cama da, devido às condições peculiares de drenagem imperfeita do pedon, facul tando a estabilidade do mineral de argila formado. Não deve ser esquecido que a adição de material a esta camada pode ocorrer, jā que a posição ocupa da por este pedon na paisagem possibilita o acúmulo de água nos períodos chu vosos, proveniente das posições mais elevadas ou mesmo por transbordamentos ocasionais do rio São Francisco.

Atravēs dos difratogramas apresentados na Figura 16 do pedọn 3 , verifica-se que o pico $14 \AA$ se mantém constante, apesar da redução de in tensidade, quando a amostra saturada: com K $\mathrm{K}^{+} \overline{\mathrm{e}}$ aquecida a $350^{\circ} \mathrm{C}$ e $550^{\circ} \mathrm{C}$, to $\underline{r}$ nando evidente a ocorrência de clorita. 0 aumento da intensidade a $10 \AA$ com o aquecimento deve-se a contração sofrida pela vermiculita passando de $14 \AA$ para $10 \AA$. A mesma amostra saturada com magnésio glicolada promove uma niti dez maior do pico a $14 \AA$ (clorita, vermiculita) e o aparecimento a $17,2 \AA$ da montmorilonita pelo aumento de seu espaçamento basal. Ainda nesta Figura 16 verifica-se também a existência de pequeno pico a $15,2 \AA$ nos 
50.

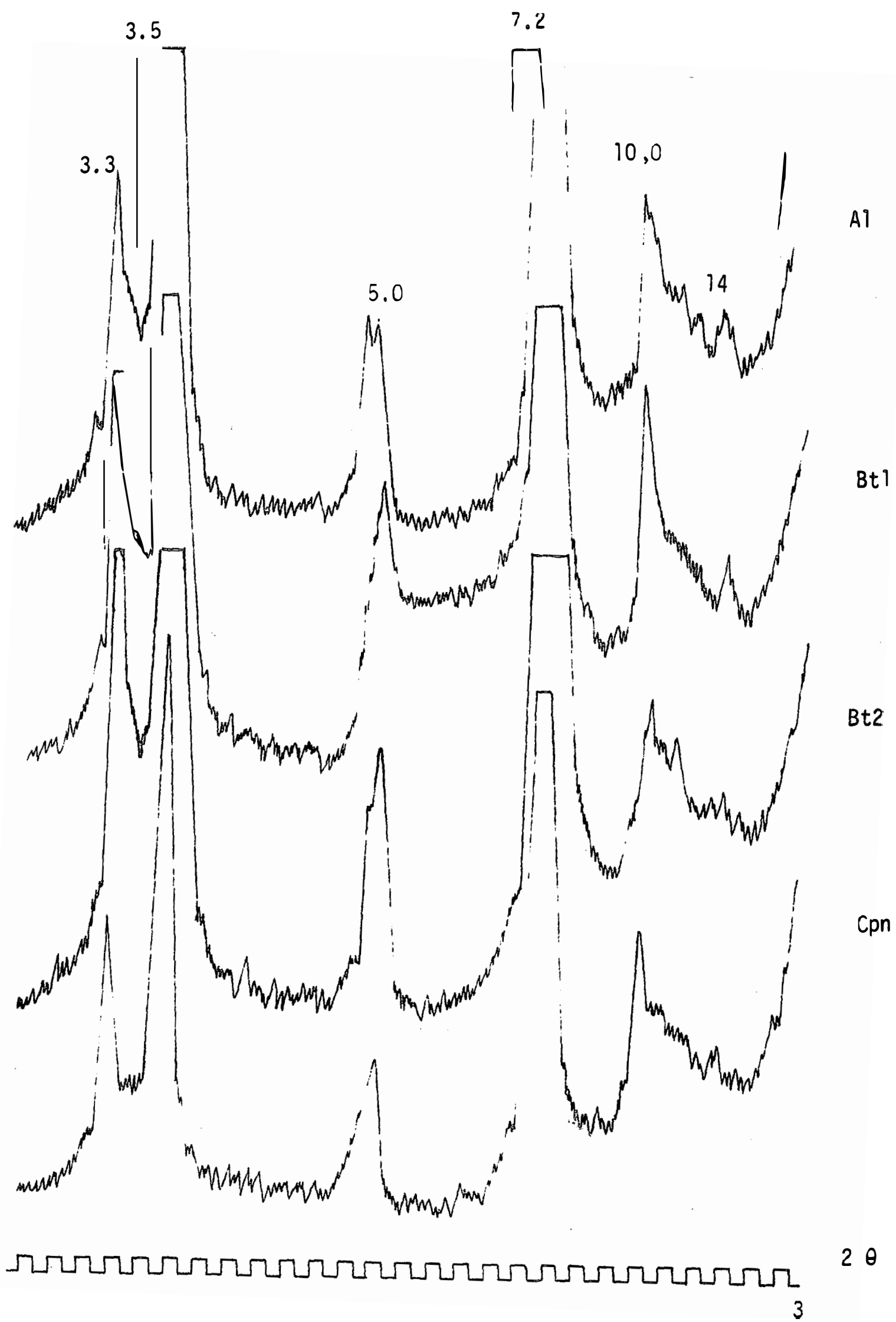

Figura 15 - Difratogramas da fração argila (< 2 u)deferrada do horizonte do pedon 3. 


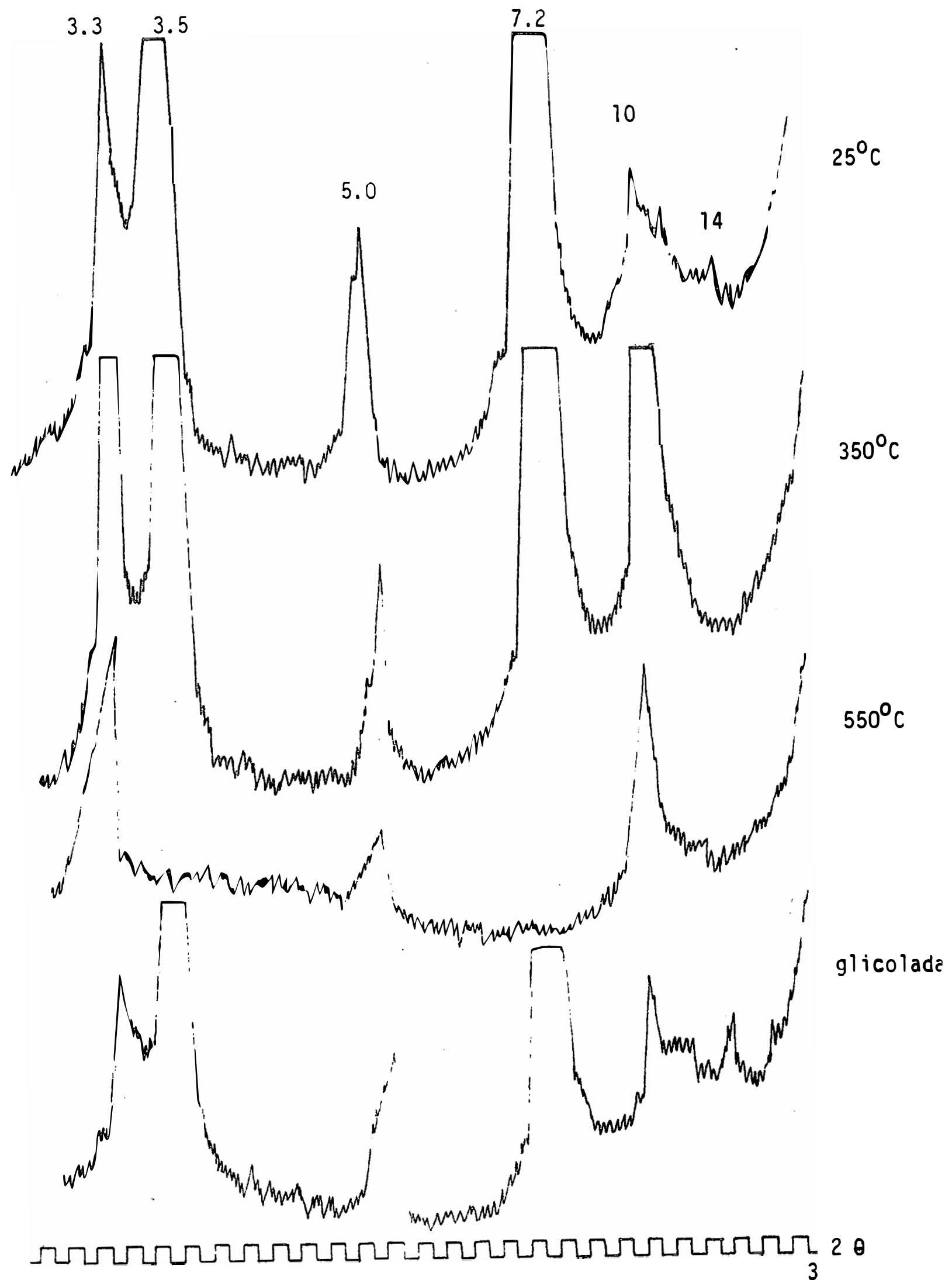

Figura 16 - Difratogramas da fração argila $: 2$ u) deferrada do horizonte $B$ do pedon 3. 
tratamentos a $350^{\circ} \mathrm{C}$ e $550^{\circ} \mathrm{C}$, desaparecendo quando a amostra e tratada com magnésio e glicolada (Bt2), possivelmente somando-se a 17,2 \& da montmorilo nita. A permanência deste espaçamento, quando aquecida e a expansão pela adição de etileno glicol sugere um mineral interestratificado como uma montmorilonita cloritizada. A ausência deste mineral nas camadas superiores estā associada provavelmente a condições de instabilidade gerada por um intem perismo mais intenso.

Os difratogramas de raios $X$ da sequência vertical dos horizon tes para 0 pedon 4 constam na Figura 17. A caulinita é o mineral de argila dominante ( > $50 \%$ ), seguida pela mica que tem os seus valores mais altos na camada superficial como ocorre no perfil 2. A figura 18 para 0 mesmo pe don, revela a presença de clorita, vermiculita e montmorilonita em pequenas proporções, identificadas em função dos tratamentos sofridos pela amostra. 0 conteúdo de minerais interestratificados tende a aumentar com a profundidade, evidenciando a sua transformação nas camadas superficiais. Considerações maiores sobre este pedon tornam-se difíceis pela série de descontinuidades litológicas presentes.

A Figura 19 representa a sequência vertical dos horizontes pa ra o pedon 5. Nota-se a dominância de caulinita em mais de $50 \%$ e de mica entre 20 e $50 \%$. Há uma certa tendência à diminuição das intensidades dos picos da caulinita em profundidade, aliada a um acréscimo nos conteúdos de mica. Este fato leva supor a transformação da mica a caulinita em superfície. Os minerais interestratificados ocorrem relativamente em menos de $10 \%$ com tendēncia a aumentar em profundidade. Por apresentar condições de boa drena bilidade, os produtos de alteração dos minerais primārios das frações $>2$ u podem estar contribuindo para o aumento da caulinita nas camadas superiores, jā que a remoção de produtos da alteração para horizontes inferiores pode ocorrer, tornando o ambiente instāvel à presença de mica como ocorre nas ca madas superiores dos pedons 2,3 e 4.

0 aquecimento a $350^{\circ} \mathrm{C}$ de amostra saturada com $\mathrm{K}^{+}$revela a con tração do espaçamento de $14 \AA$ a $10 \AA$ pelo acréscimo sofrido neste ürtimo. $\bar{A}$ 


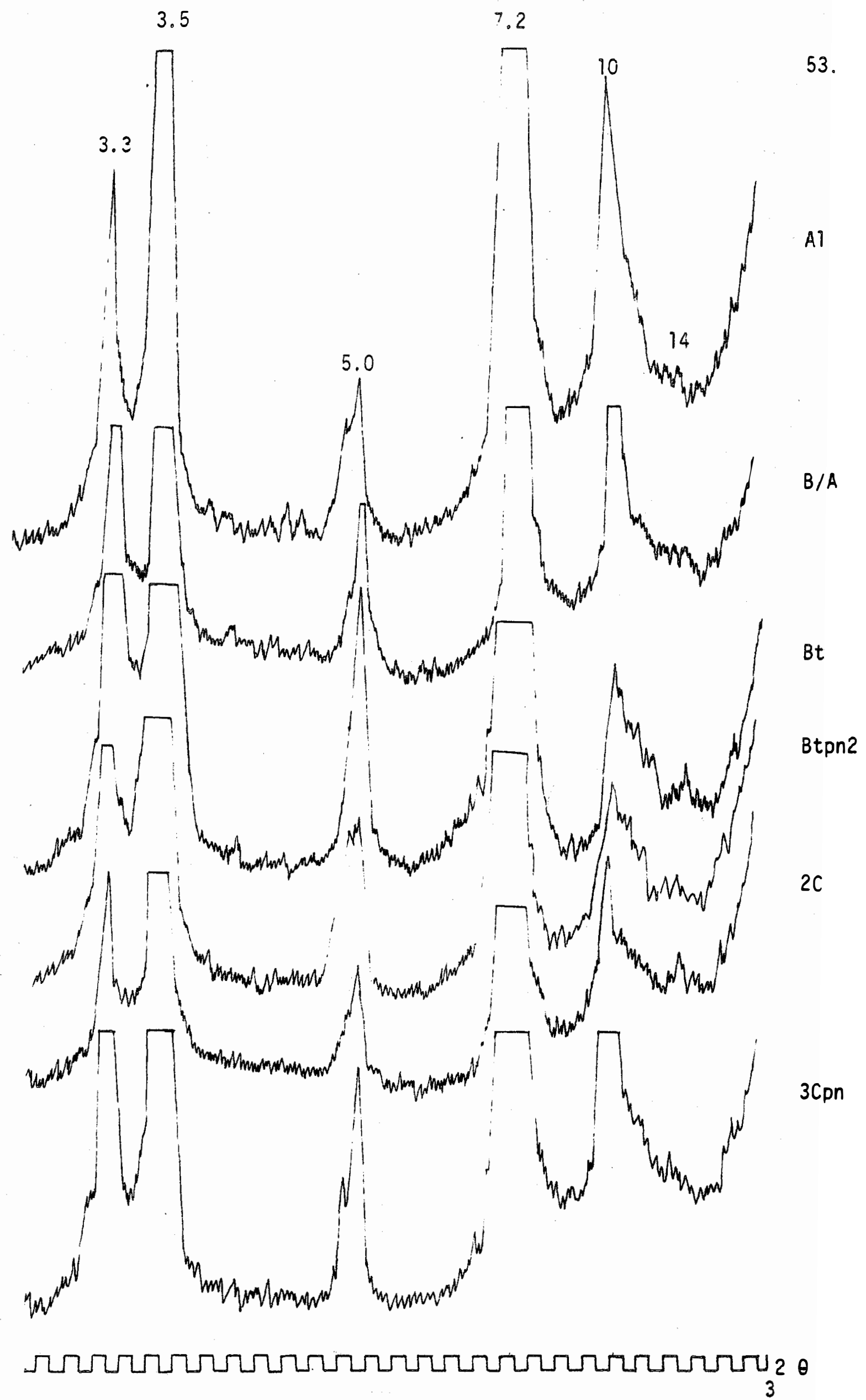

Figura 17 - Difratogramas da fração argila $(<2$ u) deferrada do horizonte do pedon 4. 


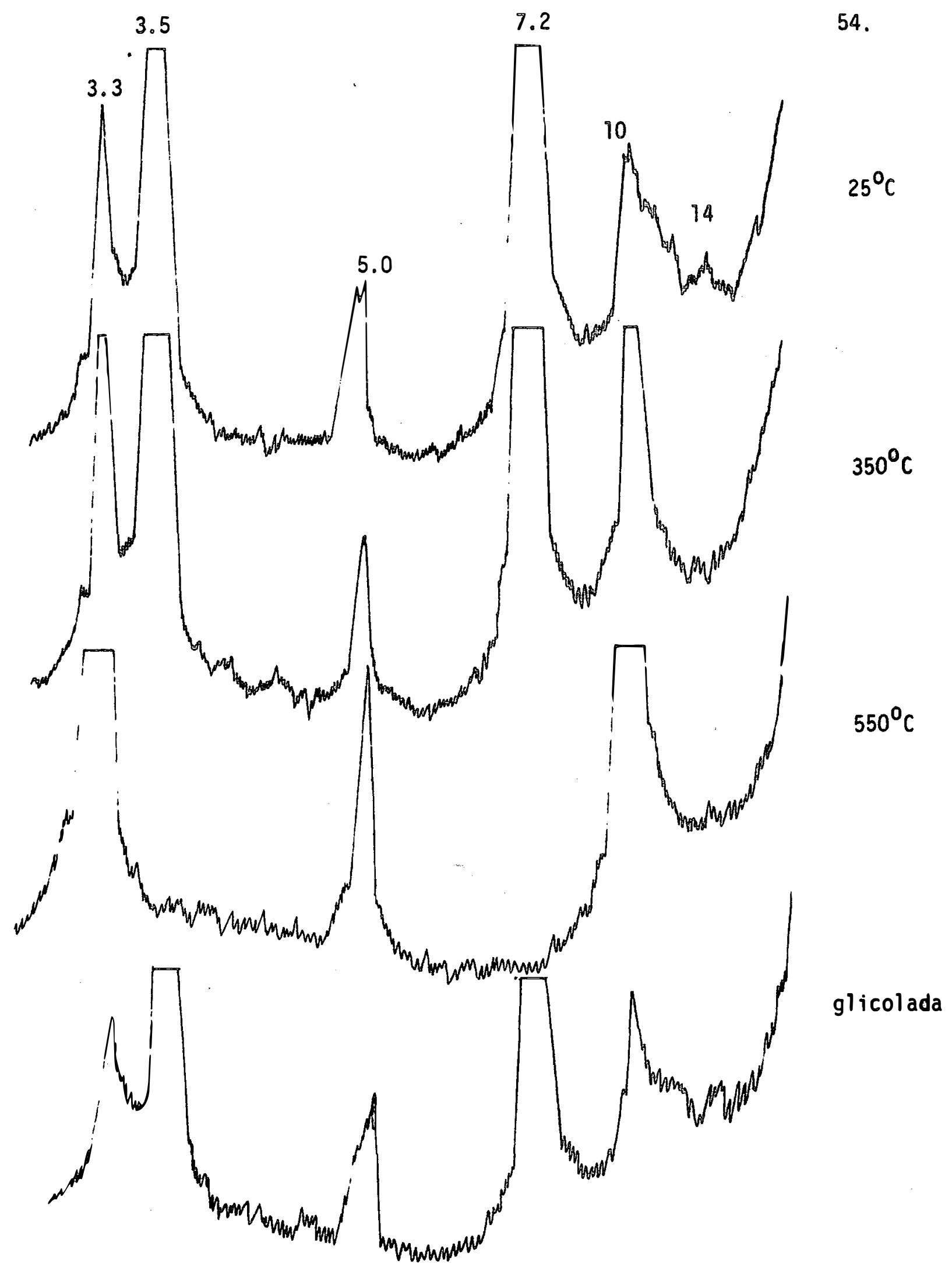

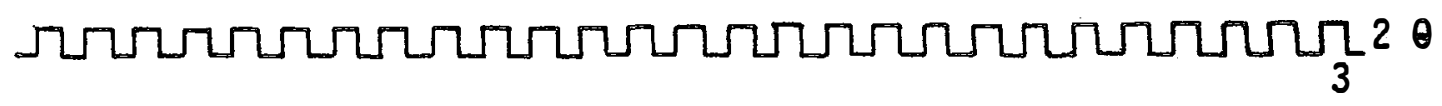

Figura 18 - Difratogramas da fração argila (< 2 u) deferrada do horizonte B do pedon 4. 


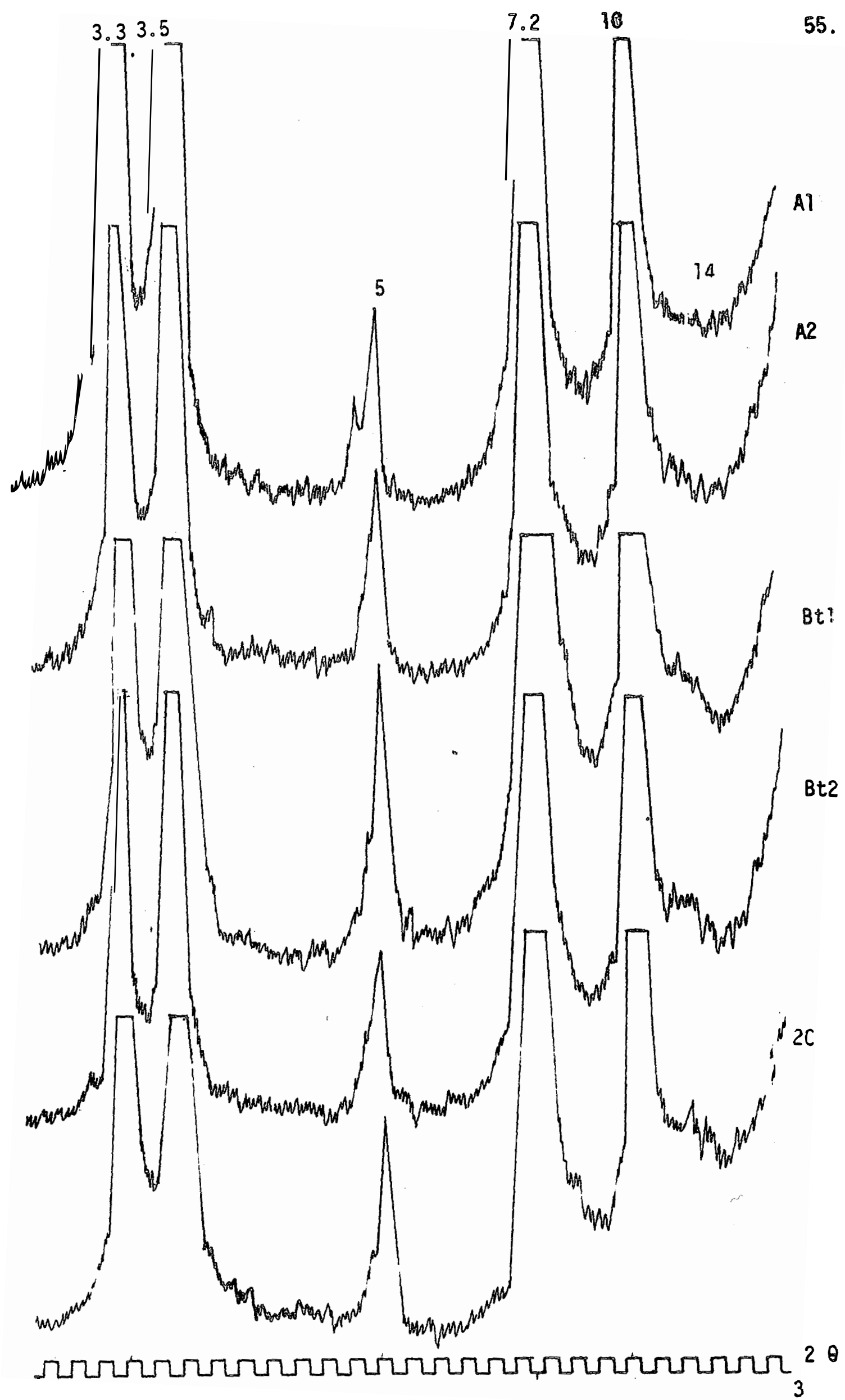

Figura 19 - Difratogramas da fração argila $(<2 u)$ deferrada do peden 5. 


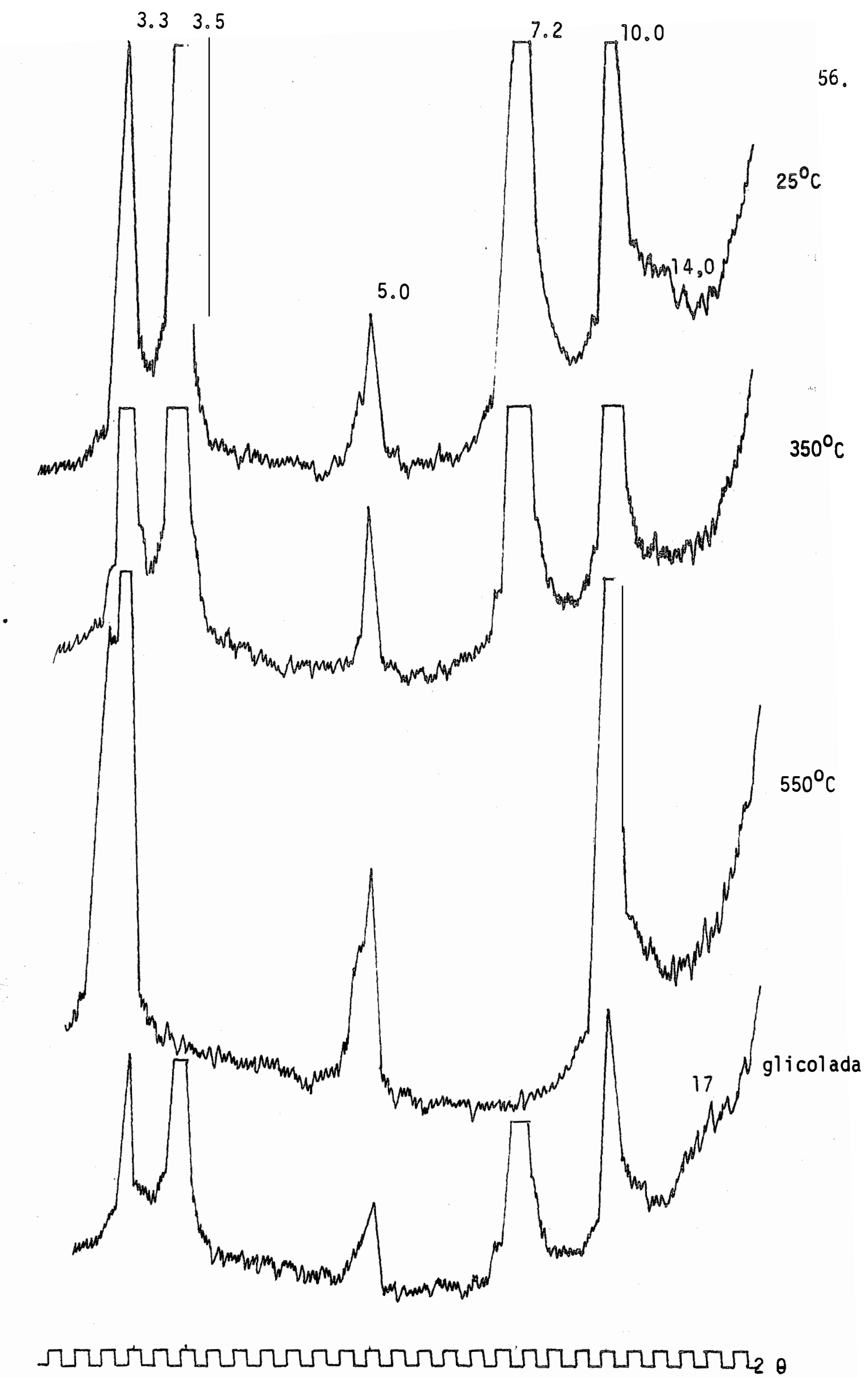

Figura 20 -Difratogramas da fração argila $(<2 u)$ deferrada do horizonte $B^{3}$ do pedon 5 . 
mesma amos tra saturada com magnésio e glicolada promove o aumento do espaça mento basal de $14 \AA$ e $17,2 \AA$, característico da montmorilonita. A ausēncia de clorita é notada pela não permanēncia de picos a $14 \AA$ nos tratamentos a que a amostra foi submetida (Figura 20). MOREIRA (informações verbais) estudando os pedons de solos da topossequēncia em questão, mostrou valores de Ki variando entre 2,02 e 2,40 para os pedons 1 e 2 entre 2,06 e 3,86 para os demais pedons. Estes valores enquadram-se no campo de estabilidade da caulinita e de minerais argilosos bissialiticos (2:1), revelando-se tambēm em maior grau de transformação mineralógica para os perfis 1 e 2 . Segundo MELFI e PEDRO (1977), estes valores de Ki estão associados a materiais de cobertura sialitica mista (pedon 1), onde o material característico do tipo de al teração é a caulinita. Para os demais pedons, a cobertura citada anteriormente associa-se à cobertura de alteração montmorilonítica, onde o processo de bissialitização é verdadeiro, contendo sempre montmorilonita associada, ou não, a vermiculita ou mica como verificado no Quadro 4.

Confrontando os resultados do Quadro 3 com os difratogramas obtidos para as frações 2 a 20 u e $<2$ u, constata-se que os solos com elevado conteūdo de minerais primārios intemperizāveis são os que apresentam a mais diversificada composição mineralógica na fração argila. Os feldspatos podem originar ilita, montmorilonita ou çaulinita na dependência da veloci dade de alteração deste mineral e da retirada do meio dos produtos solubili zados (MALAGON, 1975). Gorbunov citado por MALAGON, 1975, coloca a al tera ção dos feldspatos a hidromica, esta a vermiculita e montmorilonita, chegan do a caulinita. Considera para a muscovita a sua alteração a caulinita atra vés de uma forma de hidromica, ou a muscovita chegando a vermiculita e mont morilonita atravēs de formação de ilita.

A transformação de feldspatos em mica ē favorecida péla presen ça de ĩons $\mathrm{K}^{+}$no meio ambiente. A eliminação destes pode levar à formação de vermiculita ou montmorilonita. Em condições de alta lixiviação, o produto final dos feldspatos será a gibbsita, passando por um estāgio intermediā rio de haloisita (WILSON, 1975). STEPHEN (1952), citado pelo mesmo autor,de 
58.

monstrou que a hornblenda altera a clorita e subsequentemente para interestratificados clorita-vermiculita. Os produtos de alteração das micas são dependentes de sua estrutura e composição do meio ambiente. Elas podem alterar a vermiculita através de fenômenos complexos ou a caulinita em condições de intemperismo acentuado, passando por uma fase de verniculitização (WILSON, 1975).

OJANUGA (1973) cita a transformação de biotita em vermiculita e montmorilonita em condições de clima temperado de boa drenagem, e de caulinita em climas tropicais em condições ácidas e bem drenadas.

Os efeitos da hidrōlise parcial ou total dos minerais primä rios mantêm elevada a concentração de cátions bāsicos no meio, jā que o clị ma sub-úmido da região em estudo o permite. 0 perỉodo chuvoso concentrado em cinco meses condiciona um tempo restrito para a ocorrência de fluxo de àgua saturado, responsāvel pela lixiviação dos cátions. Assim hā condições de ocorrer a gênese de argilo-minerais com estrutura 2:1 do tipo smectita num processo denominado bissialitização (MELFI e PEDRO, 1977)。

Para os pedons estudados, a composição mineralógica das fra ções grosseiras e finas è variada (principalmente pedons 3,4 e 5) e, de acordo com os resultados obtidos, retirando a contribuição que o material de origem possa ter oferecido a minerais na fração argila, a formação de minerais secundários pode ter ocorrido segundo a sequência seguinte:

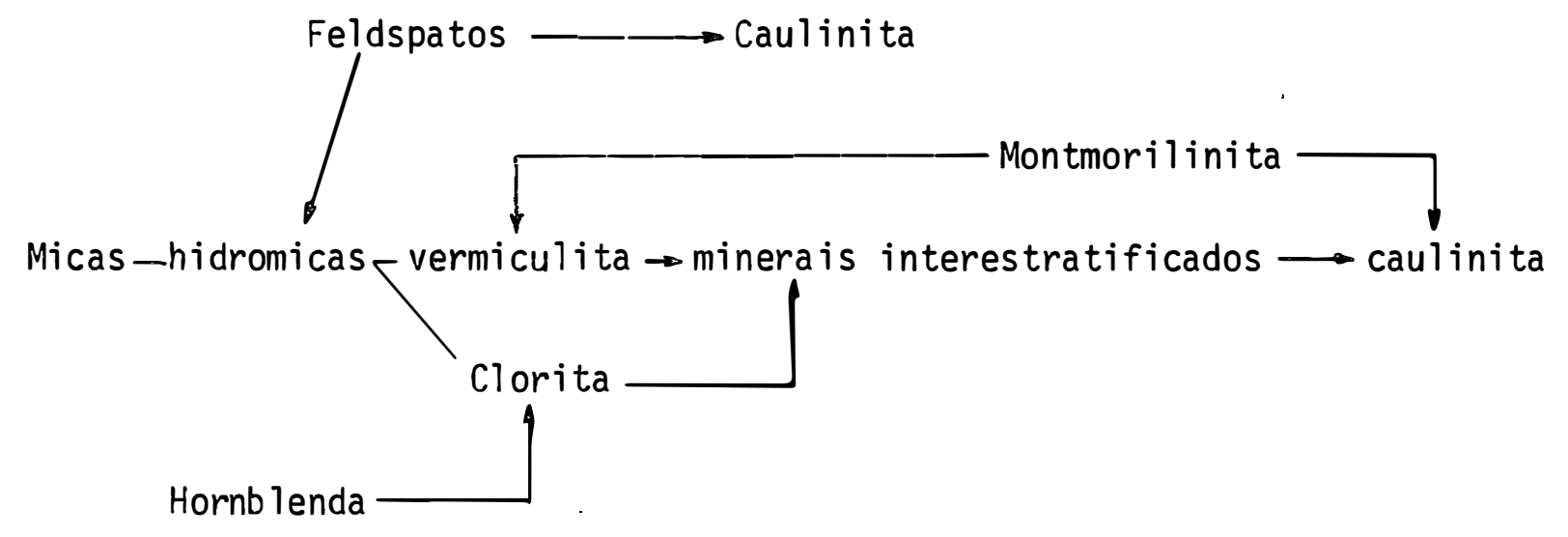


59 .

\subsection{Relação entre fisiografia e solos,}

$\mathrm{Na}$ formação e evolução da paisagem da região ora em estudo, o rio São Francisco participou de forma ativa, pois os sedimentos que a com põem são de origem aluvial.

Esta paisagem perde altitude em direção ao rio São Francisco e a diferença marcante de cota se dā no contato dos sedimentos Pleistocēnicos com os Holocênicos. A superfīcie mais antiga Pleistocēnica (PENTEADO, 1972) é a de cotas mais elevadas (Figura 21) com declividade reduzida, podendo ser considerada uma superfĩcie estável sem ação direta de processos erosivos. Nestas condições os processos de lixiviação e dessilicatização (BUOL et alii 1973) são atuantes, promovendo a transformação destes sedimen tos em solos de caracteristicas óxicas.

Analisando-se a planīcie aluvial em relação à superfīcie de erosão demarcada pela cascalheira presente na base dos sedimentos Pleistocē nicos (Figura 21), e confrontando as variações texturais existentes em um mesmo pedon, ou entre eles, pode-se inferir que para o pedon 2 a variação textural encontrada em profundidade è pertencente às duas superfícies existentes neste terraço. As texturas superficiais são as mesmas encontradas na superfície Pleistocènica, e as de profundidade, associadas às encontradas abaixo da superfīcie erosiva, demarcadas pela cascalheira. Nestas condições, o terraço onde se localiza o pedon $2 \bar{e}$ decorrente de um processo erosivo. Para os pedons 3 e 4 o ūltimo horizonte ē de caracterīsticas texturais e morfológicas semelhantes ao encontrado no pedon 2.os horizontes suprajacentes são de variação textural ampla, podendo ser correlacionados com um processo deposicional. Este mesmo processo originou os sedimentos do pedon 5 .

No processo de aluvionamento responsavel pelas feições topo grāficas da paisaaem, ocorreu a deposição de sedimentos estratificados em profundidade, estando evidenciado no exame morfológico dos pedons. Estratificações outras ocorreram (JIMENEZ, informação verbat) mas a ação dos proces 
sos pedogénicos, num perỉodo curto de tempo (Holoceno), homogeneizaram estes materiais mascarando suas evidenncias, não sendo possỉvel a diagnose em simples exame macromorfolōgico.

0 intemperismo relativo de minerais primārios para äreas 100 cais sobre superfícies de idades diferentes (RUHE , 1956) pode ser obtido pe la relação entre quartzo e plagioclāsio da fração areia, não indicando contudo um intemperismo absoluto (BREWER, 1964) em citação de RUHE (1975). Es ta relação expressa em valores médios para os pedons estudados encontra ose na Figura 22. Verifica-se nesta Figura que os pedons 1 e 2 são os que sofreram maior ação intempérica. 0 pedon 5 , apesar de ser 0 ma is rico em mine rais primärios facilmente decomponīveis (Quadro 3), mostra valores maiores para a relação quartzo/plagioclásio, evidenciando um intemperismo relativo mais acentuado, quando comparados aos pedons 3 e 4 , dentro da mesma superfi cie Holocénica. Para o pedon 3, onde existem os problemas de impedimento de drenagem e a possibilidade de inundações ocasionais, os valores de quartzo aumentam em profundidade e os de plagioclāsios diminuem no mesmo sentido. Tal situação permanece, devido a ocupar este pedon uma posição deposicional recente, tornando-a constantemente rejuvenescida nas camadas superiores por processos aditivos.

Assim, sobre os sedimentos Pleistocēnicos encontra-se o Latos solo Vermelho Amarelo (Oxissol) representado pelo pedon 1. Mineralogicamen te este solo estā em um estāgio avançado de alteração. Sua fração areia é dominada por minerais resistentes à decomposição, com valores de quartzo aci ma de $99 \%$ entre os minerais leves. A fração argila é predominantemente cau linītica. Morfologicamente o solo è profundo, com pequena distinção entre os horizontes, sendo notada principalmente por mudanças suaves no grau de estruturação, aliado a um acréscimo gradativo no teor de argila em direção às camadas mais profundas (Anexo 1). As bases trocáveis apresentam valores baixos, bem como a capacidade de troca catiōnica, devido às condições impos tas pelo processo de lixiviação e pelo retrabalhamento sofrido pelo sedimen to original. 


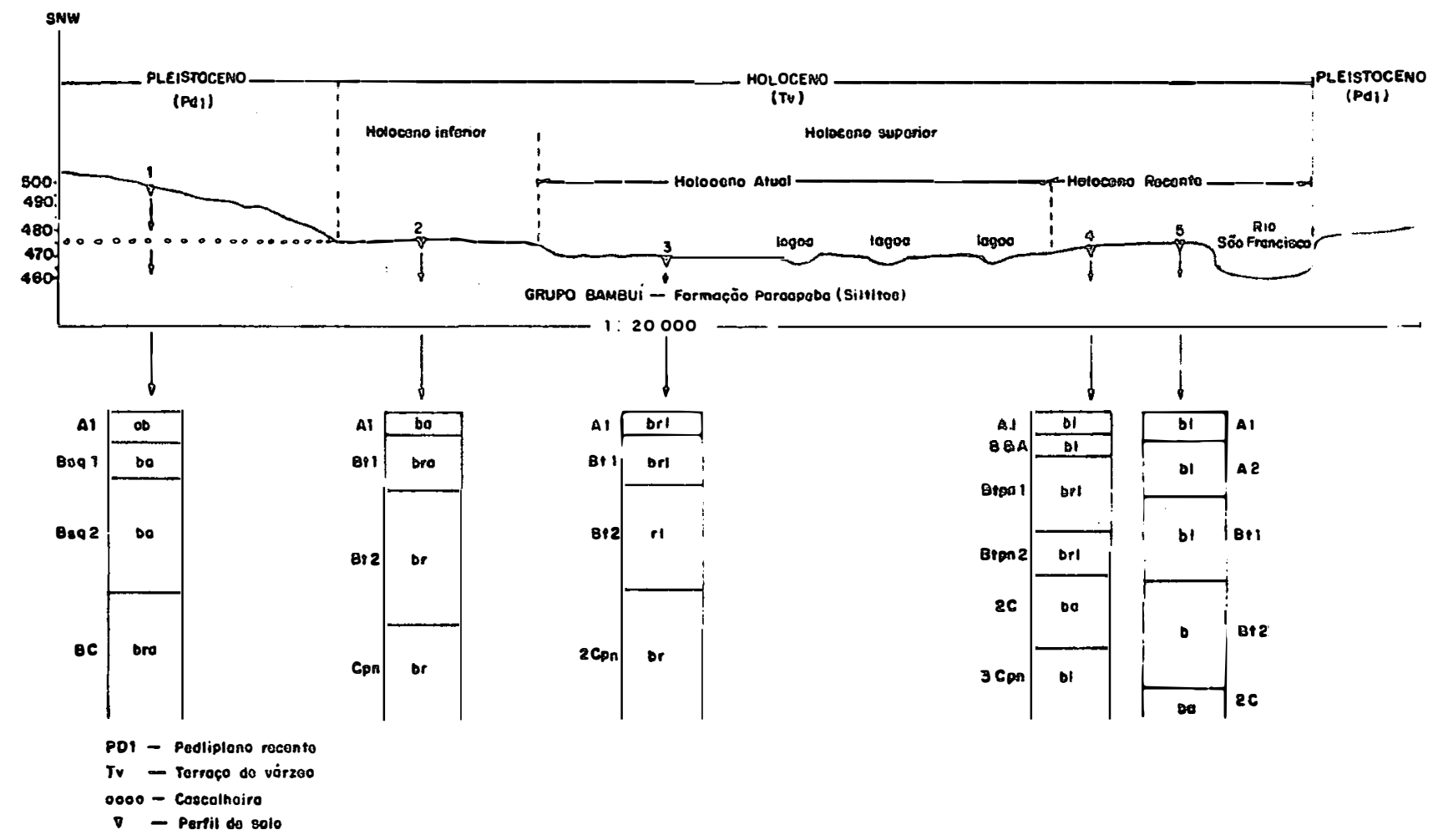

Figura 21 - Corte esquemātico geomorfolōgico da ārea estudada evidenciando sequência e classe textural dos horizontes dos pedons em estudo. 
62.

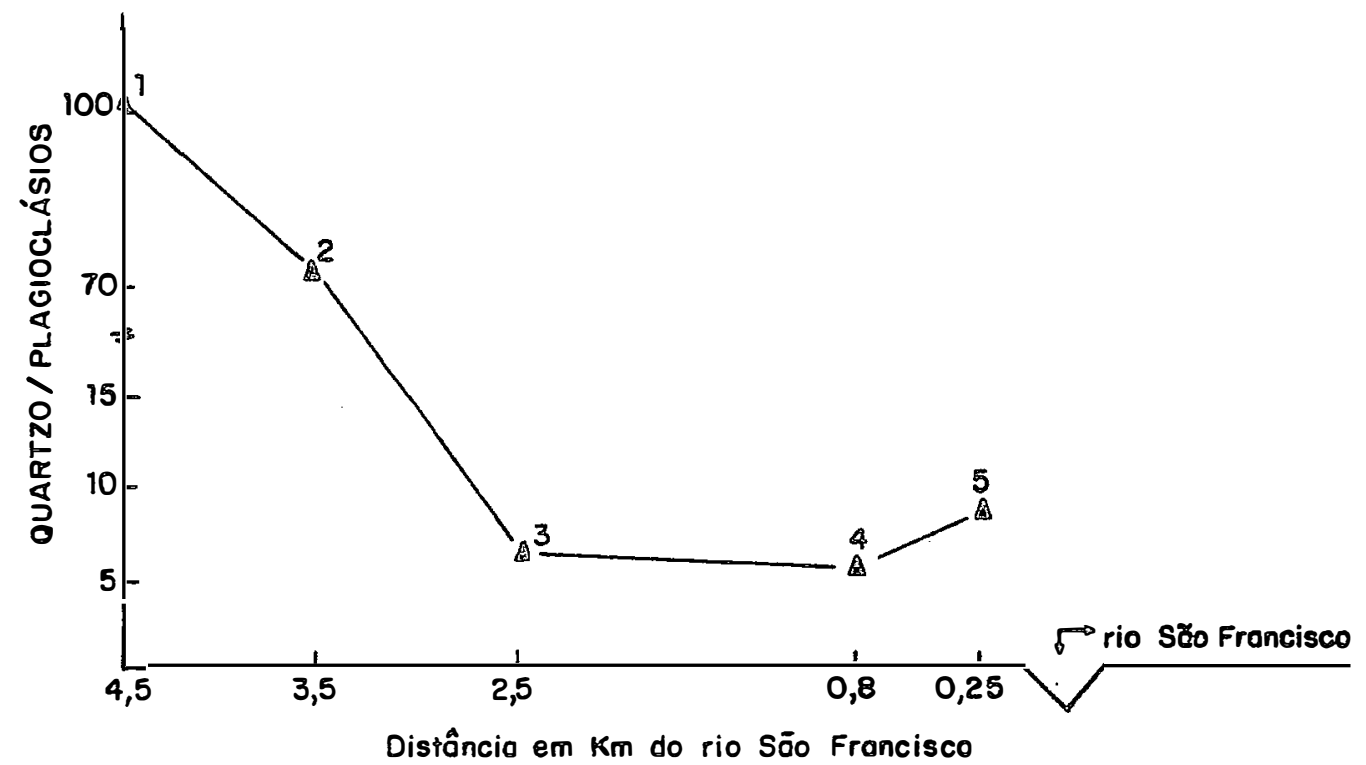

Figura 22 - Relação entre quartzo e plagioclāsios expressos em função dos valores médios dos pedons 
63.

Duas hipōteses podem ser levantadas quanto à ocorrência deste solo nesta superfície. A primeira está associada ao tempo em que este material sedimentar jă retrabalhado ficou exposto ao processo de intemperi. zação, sob a ação de alternâncias climāticas úmida e seca processadas no Pleistoceno até a atualidade, o que levou a destruição dos minerais facil mente decomponĩveis. A segunda suposição está baseada no fato de que o mate rial depositado no perỉodo Pleistocênico foi remanejado de antigos solos em avançado estágio de intemperização, não apresentando mais minerais de fácil alteração. Pouca evolução teria se processado neste material, considerandose que o clima passado poderia ter sido mais seco que o atual (PENTEADO, 1972). Considerando que, no processo de transporte e deposição deste sedimento o rio São Francisco participou de forma ativa, a contaminação com minerais primärios de menor estabilidade ao processo intempérico tornou-se ine vitāvel devido a não ser seletivo o transporte fluvial, colocando dúvidas na veracidade da segunda hipótese, quanto à ausência de minerais de fácil al teração.

Os demais pedons ocupam a planīcie aluvial Holocênica com pequenas variações de cotas e com retrabalhamento bastante intenso. Sobre sedimentos de origem fluvial recente, o tempo zero para a formação dos solos corresponde ao final do processo deposicional (DANIELS et alii, 1978), ou seja, a uma superfície estāvel, iniciando-se a partir deste ponto os proces sos pedogênicos pela formação e diferenciação de horizontes.

0 pedon 2 dentro desta planície ocupa a posição de um terraço mais antigo, fazendo contacto com a superfície Pleistocênica (Pdl). A fração areia deste solo contēm alguns minerais primārios de fácil decomposição, principalmente nas camadas mais profundas, ocorrendo o mesmo com a fração silte. A fração argila é dominada por caulinita complementada por mica, inte restratificados e traços de clorita em profundidade, conferindo-lhe um estágio de alteração inferior ao do pedon 1. As características morfológicas (Anexo 2) apontam um elevado grau de diferenciação entre os horizontes $A$ e $B$ marcados pelas variações em cor, textura, estrutura. A presença de cutans iluviais nos peds dos horizontes $B$ confere a estes horizontes caracteristi 
cas de argīlico, podendo ser classificados como um Podzōlico Vermelho Amarelo Plïntico (CES, 1977)。 Os teores de cālcio e magnēsio são baixos e os de potássio elevados, podendo estar associados à liberação por dissolução a partir da mica. A saturação de bases do complexo de troca ë baixa, conferin do a este solo um carāter distrófico (U1tissol) e um estāgio de evolução an terior ao do pedon 1 .

A posição ocupada pelo pedon 3 nesta paisagem é ligeiramente deprimida, podendo ser considerada como uma superfície deposicional. Na com posição mineralógica das frações maiores que 2 u (areia e silte), os minerais primārios de fácil alteração são comuns. Na fração argila, apesar da domināncia de caulinita ( $>50 \%$ ), existe grande contribuição de minerais de grade 2:1. 0 pedon deste solo é pouco evoluĩdo, sendo um reflexo das con dições de drenagem decorrente da posição que este ocupa. A anālise morfológica deste pedon revela a formação de um horizonte argîlico incipiente (horizonte B2) diagnosticado pela presença de cutans iluviais fracos. A estrutura desta camada é em blocos subangulares de grau forte (Anexo 3 ). Há um gradiente textural acentuado entre os horizontes $A 1$ e B2, além de elevada proporção de argila dispersa em água na camada superficial, passīvel de ser translocada para camadas profundas. Apesar da riqueza em minerais primārios de fácil alteração, este pedon ē pobre em seu conteúdo de bases trocáveis. As condições de drenagem impedida talvez sejam as responsāveis pela não dis solução dos minerais presentes. A presença de elevado teor de alumininio trocāvel confere condições para a ocorrēncia dos minerais interestratificados (JACKSON, 1964) neste pedon. Na camada inferior, os elevados conteúdos de potāssio, associados aos altos teores de $\mathrm{SiO}_{2}$ e $\mathrm{Al}_{2} \mathrm{O}_{3}$ (MOREIRA, 1979), criam ambiente para a neoformação de mica.

Os pedons 4 e 5 ocupam o terraço mais prōximo do rio São Fran cisco (Figura 20) e mostram uma série de descontinuidades litológicas em profundidade, com alternâncias de camadas sîltico-argilosas com arenosas, le vando a crer que estas mudanças texturais estejam associadas a um periodo deposicional recente. 
Mineralogicamente são solos bastante jovens, diferindo muito pouco na quantidade de minerais primärios facilmente decomponīveis (feldspa tos cālcio-sódicos, hornblenda), nas frações areia e silte. Na fração argila a caulinita aparece com mais de $50 \%$, seguida de mica, interestratificados, vermiculita e montmorilonita.

No pedon 4, os caracteres morfológicos ressaltam a estruturação bem desenvolvida nos horizontes $B$ e a abundância de cutans iluviais nas superfícies dos peds em grau de desenvolvimento forte (Anexo 4). A relação entre argila do horizonte $B / A$ é superior a 1.3 reforçando a ocorrência do horizonte argīlico neste pedon, possibilitando classificá-lo como Podzólico Vermelho Amarelo Plïntico. Os teores de cálcio e magnésio são maiores na superfície, estando associados ao processo de reciclagem através da cobertu ra vegetal. 0 alumīnio-trocável aumenta com a profundidade, conferindo ao pedon caracterīstica distrōfica (U1tissol). As considerações a respeito do comportamento do aluminnio são as mesmas do pedon anterior.

Para o pedon 5 os dados morfológicos ressaltam a presença de horizonte mōlico em superfície confirmado pèla anālise química (Anexo 5). 0 desenvolvimento forte de estrutura, a presença de cutans iluviais e a eleva da relação do teor de argila entre horizontes $B$ e $A$, conferem a este pedon os caracteres de horizonte argỉlico. Por apresentar melhor condição de drenagem quando comparado com os pedons 3 e 4, a composição mineralógica deste perfil vem sofrendo alteração, como pode ser constatado pelas quantidades elevadas de bases trocáveis presentes. 0 intemperismo tem atuado e os produtos de solubilizäção permanecido no meio, devido às condições climāticas, apesar da boa drenabilidade. 0 conteúdo de argila dispersa em água é elevada, principalmente nos horizontes $A$, facultando a lessivagem para as camadas mais profundas, ocasionando um aumento no teor de argila do horizonte $B$. A ocorrēncia de um horizonte $B$ textural de características eutrōficas e a pre sença de um epipedon mōlico possibilitaram enquadrar este perfil como Bruni zem (CES, 1977). 
66.

Na superfície Holocênica, considerando principalmente os perfís 4 e 5, a evolução morfológica expressa pelo grau de estruturação, alia do ao desenvolvimento acentuado de cutans iluviais nas superfícies dos peds nos horizontes $B$, é contrastante com a maturidade dos sedimentos. A ocor rência de horizontes argīlicos nestes pedons contrariam a relação entre solo e a paisagem, que os admite em posições e sedimentos mais antigos BuboL et alii, 1973). Apesar de estar próximo ao rio São Francisco em superfície deposicional, os pedons 4 e 5 estiveram em condições estāveis, não sofrendo contribuições detectāveis deste rio na atualidade. A estabilidade desta superfície aliada a fatores climáticos, drenagem e à variada composição mineralógica, em minerais primários capazes de se alterarem dando formação de argilas, ou a pré-existência destas na composição dos sedimentos, foram os responsāveis pela formação dos horizontes argīlicos nesta superfície, a partir do marco zero (final do periodo deposicional). Os processos de translócação e acumulação iniciaram concomitantemente à deposição dos sedimentos , promovendo acentuada redução no tempo de evolução destes pedons.

\subsection{Classificação dos solos}

Baseado nos resultados morfológicos, químicos, físicos e mineralógicos, obtidos para os solos em estudo, procurou-se classificá-los ao nīvel de família, segundo os critérios do SOIL TAXONOMY (1975). A classificação pelos conceitos do sistema brasileiro (BENNEMA e CAMARGO, 1964). encontrase no Quadro 2.

0 pedon 1 (LVA) apresenta um epipedon ócrico e um horizonte diagnóstico de sub-superfície $0 x i c o$. Estas características possibilitam enquadrā-10 como um 0xissol ao nível de ordem. De acordo com as características do clima, umidade do solo, e dos horizontes diagnósticos, a subordem é Ustox e o grande grupo Haplustox. As características de textura, mosqueado, saturação em bases, estrutura, mineralogia e temperatura, fazem com que este pedon seja classificado como Typic Haplustox a nível de sub-grupo e na família Ty pic Haplustox barro fino, silicoso, caulinítico, isotérmico. 
A presença de horizonte argĩlico no pedon 2 (PVAplil), associa do ao epipedon ōcrico, ao regime ústico e à baixa saturação em bases, possibi lita classificá-10 na ordem Ultissol, subordem Ustult. Os resultados mineralógicos e a presença de plintita na camada mais profunda, coloca este pedon no grande grupo Haplustult e subgrupo Plinthic Haplustult. Ao nīvel de família este solo cliassifica-se como Plinthic Haplustult barro fino, silicoso, caulinîtico isotérmico.

0 pedon 3 (LH) apresenta um epipedon ócrico e um horizonte ar gîlico como diagnóstico de subsuperfície. Por ocorrer em uma posição deprimi da, mostra sérios problemas de drenagem, estando sujeito a inundações ocasio nais, conferindo-lhe condições paræ ser classificado na ordem Ultissol, subordem Aquult. A presença de fase contínua de plintita e a capacidade de troca de cátions, coloca-o no grande grupo Plinthaquult e subgrupo 0xic Plintha quult. A distribuição das classes de partĩculas, a mineralogia e o regime de temperatura enquadram-no como oxic Plinthaquult, fino, misto, isotérmico.

As características morfológicas, analíticas e mineralōgicas do pedon 4 (PVApd2) possibilitam classificā-lo na ordem Ultissol, subordem Ustult, grande grupo Plinthustult. A posição ocupada por este pedon é a de um terraço deposicional recente elaborado pelo rio são Francisco. Ao nĩvel de família este solo foi classificado como Fluventic Plinthustult, silte fino, misto, isotérmico.

No pedon 5 (BA) ocorre um epipedon mōlico sobre um horizonte argīlico em um regime de umidade ústico, ficando este solo na ordem Molissol, subordem Ustoll e grande grupo Argiustoll. Os sedimentos de origem sofreram as mesmas influências do pedon 4 (PVAp12). Este pedon, ocupando um terraço fluvial recente, enquadra-se como Fluventic Argiustoll em subgrupo, e na famīlia Fluventic Argiustoll, barro fino, misto, isotērmico. 
68.

6. CONCLUSÕES

- Tódos os pedons estudados são formados por material retrabalhado.

- Os pedons com horizonte argîlico são menos evoluĩdos do que o solo com horizonte óxico conclusão esta evidenciada pela presença de minerais facilmente intemperizáveis nos primei ros solos e ausência neste ültimo.

- A presença de horizonte argílico nos sedimentos holocênicos do rio São Francisco evidencia que contrariamente ao que se tem atribuido, tal horizonte necessariamente não necessita de um longo tempo para a sua formação.

- Os minerais facilmente decomponiveis (hornblenda+plagioclásios) diminuem a medida que distancia-se do rio São Francis co, chegando a desaparecer completamente no 0xissol.

- A caulinita é o mineral dominante para todos os solos estudados, entretanto o teor de minerais de retículo 2:1 aumenta sensivelmente em direção ao rio.

- 0 pedon 1 se desenvolve em superfície estável pleistocênico onde os processos de lixiviação e dessil icatização são atuan tes enquanto os demais se desenvolvem em superfícies mais ins tãveis holocênicas. 
- Através do intemperismo relativo de minerais primários os pedons 1 e 2 sã் os que sofreram a maior ação intempérica e o pedon 5 apesar de ser o mais rico em minerais primários facilmente decomponíveis (hornblenda+plagioclāsios), mostra valores maiores para a relação quartzo/plagioclásio, eviden ciando um intemperismo relativo mais acentuado, quando compardos aos pedons 3 e 4 ,dentro da mesma superfície Holocênica.

- Para a fração silte fino os menores teores de minerais primārios facilmente decomponíveis e dos secundārios como caulinita foram encontrados na superfície Pleistocênica (Oxissol).

- Houve tendênciàldál caulinita diminuir em profundidade nos di ferentes pedons na fração silte fino. No mesmo sentido houve acréscimo no conteúdo de mica.

- A caulinita como mineral dominante nos pedons estudados,pode ter sido herdada do próprio material de origem e/ou formada "in situ",pela transformação dos feldspatos, micas e hornblen da presentes nas frações mais grosseiras,passando ou não por fases intermediārias de clorita (vermiculita,montmorilonita e interestratificados).

- A fertilidade potencial, expressa em termos de reserva minera lógica,quer em minerais primārios ou secundārios, passīveis de alteração,aumenta a medida que a idade relativa dos pedons diminui.

- Os pedons estudados foram classificados como: Typic Haplustox barro fino, silicoso, caulinítico, isotérmico (Pedon 1): Plinthic Haplustult barro fino, silicoso, caulinitico (Pedon 2) ; Oxic Plinthaquult fino, misto, isotérmico (Pedon 3); Fluventic Plinthustult, silte fino, misto, isotérmico (Pedon 4) e Fluven tic Argiustoll, barro fino, misto, isotérmico (Pedon 5). 
70.

7. SUMMARY

Mineralogical characteristics was conducted in a toposequence of five pedons developed from Quaternary sediments of variable composition, in the "São Francisco" valley, northeast Minas Gerais state.

Physiographical aspects and its correlations with soils were studied. In the oldest surface (Pleistocene) the soil is very weathered (pedon 1 ) classified as Typic Haplustox. The other soils are located in the Holocenic sediments, the alluvial area of São Francisco river. These are less weathered soils (molisol and ultisol) with argillic horizons.

Pedon 1 has only resistent minerals in its sandy fraction. The clay fractions is characterised by dominance of kaolinite, associate with mica and interestratified minerals (vermiculite chloritezed), that in creace in depth. Pedon 2 (Plinthic Haplustult) has plagioclase and mica in sandy fraction, increasing in depth. Plagioclases does not occurs in fi ne silty. Clay fraction is predominantely kaolinitic with low amount of mica and interestratified.

Pedons 3 (0xic Plinthaaquult), 4 (Fluventic Plinthustult) and 5 (Fluventic Argiustoll) shown high amount of plagioclases and hornblend in sand and silt fractions. Kaolinite is the more abundant mineral in 
clay fraction, of these soils, but others minerals also ocours, mainly 2:1 (mica, vermiculite and montmorillonite) and 2:2 (chlorite). 
72.

\section{BIBLIOGRAFIA CITADA}

AGENCY FOR INTERNATIONAL DEVELOPMENT - AID. Rio São Francisco Basin -Bra sil, reconnaissance a apraissal land and wather resources. 1967, vol. 1.

AOMINE, S. e K. WADA. Differential weathering of volcanic ash and pumic, resulting in information hidrated halloysite. Am mineralogist 47:1024, 1962.

BALSTER, C.A. e R.B. PARSONS. Geomorphology and soils. Willamette va 1ley, Oregon. Oregon State Agric. Expe. stn. Spec. rep. 265:8-22. 1968.

BENNEMA, J. e M.N. CAMARGO. Segundo esboço parcial de classificação de solos brasileiros. DPFS, Ministério da Agricultura. Rio de Janeiro, 1964.

BILZI, A.F. e J. CIOLKOSZ. Time as a factor in the genesis of four soils developed in recent alluvium in Pennsylvania. Soil Sci. Soc. Am. 41 (1): 122-127. 1977. 
BLOSS, F.D. An introduction to the methods of optical crystallography. Holt, Rinehart and Wiston, Inc. 1961. $294 \mathrm{p}$.

BRASIL. MINISTERIO DA AGRICULTURA. Normais climatológicas. Rio de Janei ro, 1969. Vol. III, $99 \mathrm{p}$.

BRAUN, O.P.G. Contribuição a geomorfologia do Brasil central. Rev.Bras. Geogr. 32 (33): 3-39.

BREWER, R. Fabric and mineral analysis of soils. New York, John Wiley \& Sons, 1964.

CAVALCANTI, A.C. Estudo de latossolos argilosos do Planalto Central do Brasil - caracterização, distinções de acordo com duas superfícies de aplainamento, gênese e classificação. Tese M.S., apresentada na UFRRJ, Rio de Janeiro, 1977, 186 p.

CENTRO DE ESTUDOS DE SOLOS. Departamento de Solos, Geologia e Fertilizantes, ESALQ-USP. Levantamento semi-detalhado dos solos do projeto Jequitaī (MG). Piracicaba, CODEVASF-CES. 1977.

CENTRO DE ESTUDOS DE SOLOS. Departamento de Solos, Geologia e Fertilizantes, ESALQ-USP. Levantamento de reconhecimento dos solos do projeto Corrente Divisão Correntina (BA), Piracicaba, CODEVASF-CES, 1973.

CENTRO DE ESTUDOS DE SOLOS. Departamento de Solos, Geologia e Fertilizantes, ESALQ-USP. Levantamento de reconhecimento dos solos do vale do rio Jẹuitaí. Piracicaba, CODEVASF-CES, 1971.

CENTRO DE ESTUDOS DE SOLOS. Departamento de Solos, Geologia e Fertilizantes, ESALQ-USP. Levantamento de solos do projeto das Velhas (MG). Piracicaba, CODEVASF-CES, 1975. 
DANIELS, R.B.; E.E. GAMBLE $e$ W.H. WHEELER. Age of soil landscapes in the Coastal plain of North Carolina. Soil Sci. Soc. Am. J. 42(1): 98-105, 1978.

DEMATTEE, J.L.I. Gênese e classificação de solos originados do grupo geológico Estrada Nova - Municỉpio de Piracicaba, SP. Tese de Livre- Docência ESALQ-USP, 1970.

DHAMPAT, R. $e$ W. L. LINDSAY. A thermodynamic model for predicting of formation, stability, and wheathering of common soils minerals. Soil Sci. Soc. Am. Proc. 39, 1975.

EMPRESA DE PESQUISA AGROPECUARIA DE MINAS GERAIS. Levantamento de reco nhecimento com detalhes dos solos do Distrito Agroindustrial de JaibaMinas Gerais. Boletim Técnico nọ 54, 1976.

FAUCK, R. Evolution des quartz dans le sols rouges ferrallitiques devellopés sur les roches sableuses et greseuses de l'Afrique occidentale. Compte Rendu Ac. Sc. Paris (71): 2273-2276, 1970.

GEIGER, P.P. Geomorfologia. In: Geografia do Brasil - Grande Região Centro Oeste. Cons. Nac. Geogr., IBGE. 1960, vol. II. Série A. p. 9-59.

GILE, L.H. e R.B. GROSSMAN. Morphology of the argillic horizon in desert soils of the southern New Mexico. Soil Sci. 106: 6-15, 1968.

GILE, L.H. e J.W. HAWLEY. Age and comparative development of desert soils as the gardner spring radicarbon site. New Mexico. Soil Sci. Soc. Am. Proc. 32: 709-716, 1968. 
GOLDMAN, M.L. e J.I. TRACEY JR. Relations of bauxite kaolinite in the Ar kansas bauxites deposits. Econ. Geol. 41: 567-575, 1946.

GORBUNOV, N.I. Individual and interestratified minerals in soils and their identification by the $x$-ray method. Soviet soil, Sci. 9: 1288 $1300,1968$.

JACKSON, M.L. Clay transformation in soil genes is during the quaternary. University of Wiscons in, 1964.

JACKSON, M.L. e G.D. SHERMAN. Chemical weathering of minerals in soils. Advanced Agronomi。 5:219-318, 1953.

JACKSON, M.L. Soil chemical analysis: advanced course. Madison, Univ. of Wis. Department of Soil Science, 1965. $991 \mathrm{p}$.

JACKSON, M.L.; B.A. TYLER; A.L. WILLIS; G.A. BOURBEAU E R.P. PENNINGTON. Weathering sequence of clay size minerals in soils and sediments: I Fundamental generalization. Jour. of Phys and Colloid Chemistry. 52: 1237-1260. 1948.

JACOMINE, P. e T. KLINGER. Descrição das características morfolōgicas, físicas e quīmicas e mineralógicas de alguns solos sob vegetação de cer rado. Bol. Téc. (11) Min.Agric. EPPS, Rio de Janeiro, 1974, 126 p.

KERR, P.K. Optical mineralogy. 3cd. McGraw-Hill, 1959.422 p.

KLING, L.C. Geomorfologia do Brasil ocidental. Traduzido por Roberto Galvão. Rio de Janeiro. Bras. Geogr. 18 (2): 147-165. 1957. 
76.

KITTRICK, J.A. Soil minerals in the $\mathrm{Al}_{2} \mathrm{O}_{3}-\mathrm{SiO}_{2}-\mathrm{H}_{2} \mathrm{O}$ system and a theory of their formation. Clay and clay minerals. 17: 157-167. 1969.

LEPSCH, I.F.; S.W. BUOL e R.B. DANIELS. Soil landscape relationships in the ocidental plateau of São Paulo, Brasil. Geomorfic surfaces and mapping units. Soil Sci.Am. J. 41 (1), 1977.

LEPSCH, I.F.; S.W. BUOL e R.B. DANIELS. SOil landscape relationship in the ocidental plateau of São Paulo, Brasil. II. Soil morfology, genesis and classification. Soil Sci. Am. J. 41 (1), 1977.

MALAGON, D.C. Mineralogia de suelos sus relaciones con gēnesis, fertilidad y clasificaciōn de suelos. Instituto Geogräfico "Agustin Codazzi" Sub-direccion Agrologia, vol. XI nọ 1. Bogotā D.E. Colombia, 1975.

MATTOS, J.T. e R. PEREIRA DA CUNHA. Aplicação de sensores remotos com ènfase a imagens de Landsat em mapeamento geológico no Norte de Minas Gerais. Tese de Mestrado, INPE, São Josē dos Campos, SP. 1977.

MELFI, A.J. e G. PEDRO. Estudo geoquīmico dos solos e formações superficiais do Brasil. Caracterização e repartição dos principais tipos de evolução pedogeoquímica. Rev. Bras. Geog. 7 (4): 271-286, 1977.

MONIZ, A.C. e M.L. JACKSON. Quantitative mineralogical analys is of Brasi lian soils derived fron basaltic rochs and state. Wisconsin. Soil Sci. Report 212, 1967. 24 p.

MONIZ, A.C.; P.K. KIYOHARA; A. CARVALHO e P.de SOUZA SANTOS. Natureza mi neralógica da fração argila de solos derivados do Arenito Bauru no Muni cipio de Pindorama, SP. Anais do XV Cong. Bras. Cienc. Solo - Soc. Bras. Ci. do Solo. Campinas, SP - Brasil, 1976. 
NETTLETON, W.D.; J.E. WITTY; R.E. NELSON e J.W. HAWLEY. Genes is of argilic horizons in soils of desert areas of Southwestern United States. Soil Sci. Am. J. 39 (5): 919-926. 1975.

OJANUGA, A.G. Weathering of biotite in soils of a humid tropical climate. Soil Sci. Soc. Am. Proc. 37 (4): 644-646, 1973.

PARSONS, R.B. e R.C. HERRIMAN. Geomorphic surfaces and soil development, upper Rogue river valey, Oregon. Agron. Abst., 1975. 154 p.

PENTEADO, M.M. Caracterização geomorfolōgica da região de Pirapora, Jequitaĩ e Värzea da Palma. Notīcias Geomorfolōgicas, 1972.

PENTEADO, M.M. e G. RANZANI. Relatōrio de viagem do médio vale do rio São Francisco. (Mimeo.), Piracicaba, ESALQ, 1970, 50 p.

PERES MATEOS, J. Anālisis mineralōgico de Arenas. Patronato "Alonso de Herrera". Madrid, 1964. 265 p.

PONCANO, W. L. e A.F. PAIVA. Mapa geológico preliminar da região de Jequi taî, Minas Gerais. In: Cong. Bras. Geol., Belēm. Anais 1:95-102, 1972.

RUELLAN, F. Alguns dos aspectos do relevo do planalto central do Brasil. In: Anais da A.G.B., vol. II. 1952.

RUHE, R.V. Geomorphology - Geomorfic processes and surficial geology. Li brary. of Congress Catalog Card Number, 74-114. New Jersey USA, 1975.

RUHE, R.V. Geomorphic surfaces and the nature of soils. Soil Sci. 82: 441-445. 1959. 
78.

SOIL SURVEY MANUAL. SOil survey staff. U.S.D.A. Handbook nọ 18. Washington, D.C., Gout. Printing Office, 1951. 503 p.

SOIL F'AXONOMY. (Em publicação). Designaciōn de horizontes.

SOIL TAXONOMY. A BASIC SYSTEM OF SOIL CLASSIFICATION FOR MAKING AND INTER PRETING SOIL SURVEYS. SOil Survey Staff. Washington, U.D. Department of Agriculture, Soil Conservation Service. Agriculture Handbook no 436, 1975. $754 \mathrm{p}$.

STEPHEN, I. A study of rock weathering with reference to the soils of the Malvern Hills. Part 2. Weathering of appinite and Ivy Scar.Rocks. J. Soil Sci. 3:219-237. 1952.

THORNTWAITE, C.W. An approach toward a rational classification of climate. Geogr. Rev. 38: 55-94. 1948.

THORNTWAITE, C.W. e J.R. MATHER. The water balance. Publ. In: Climato logy. Center. N. J., 1955. Vol. III nọ 1.

WARSHAW, M.C. e R. ROY. Classification and scheme for identification of layers silicates. Bul. Geol. Soc. Am. 72: 1455-1492. 1963.

WEAVER, R.M. Soils of the central plateau of Brazil. Chemical and mine ralogical properties. Agron. Min. 74-8. Cornell University, Ithaca, N.Y. 1974.

WILSON, M.J. Chemical weathering of some primary rock-forming minerals. Soil Sci. 119(5): 349-355. 1975. 
79.

9. APENDICE 
80.

PEDON 1

CLASSIFICAÇAO: LATOSSOLO VERMELHO AMARELO, EPIEUTROFICO; Aliico, A fraco, textura média.

LOCALIZAÇAO: Estrada Pirapora-Montes Claros, aproximadamente $1 \mathrm{~km}$ de Guaicui pelo lado esquerdo a 700 metros desta por uma secun dária que leva a margem direita do rio são Francisco.

GEOLOGIA: Quaternārio-Pleistoceno.

MATERIAL DE ORIGEM: Sedimentos areno-argilosos.

RELEVO LOCAL: Plano.

RELEVO REGIONAL: Suavemente ondulado.

VEGETAÇAO: Cerrado secundārio.

DRENAGEM: BOa.

MORFOLOGIA:

A1

0- $12 \mathrm{~cm}$; pardo (7,5YR 5/4 úmido) com pardo escuro $(7,5 Y R$ 4/2) médios, distintos, $40 \%$; areia barrenta (ab): granular média, fraca, muito friāvel, não plástico, não pegajoso; raízes fi nas abundantes, médias a grossas, comuns; galerias biolōgicas menores que $5 \mathrm{~mm}$, abundantes; acumulaçōes de matēria or gânica, comuns; poros finos e médios, caōticos, descontínuós, abundantes; deposição de $10 \mathrm{~mm}$ aproximadamente, de areia em superfície; limite ondulado, claro. 
Bsql 12- $32 \mathrm{~cm}$; alaranjado (5YR 5/6 úmido); barro arenoso (ba); prismátí ca média que se rompe em blocos subangulares, médios, freco; muito friāvel, ligeiramente plástico, pegajoso; raízes mēdias e grossas, abundantes; galerias biológicas menores que $10 \mathrm{~mm}$, abundantes, algumas com paredes cerosas; poros médios, oblíquos, descontínuos, abundantes: limite ondulado, gradual.

Bsq2 32- $92 \mathrm{~cm}$; alaranjado (5YR $5 / 6$ úmido); barro arenoso (ba); blocos subangulares médios, fraco; muito friāvel, ligeiramente plás tico, pegajoso; raizes médias, comuns; galerias biológicas menores que $10 \mathrm{~mm}$, comuns, algumas com acumulações de argila cimentando quartzo fino; poros médios, verticais e horizontais, descontínuos, abundantes; limite ondulado, difuso.

B/C 92-150+cm; alaranjado (5YR 5/6 úmido); barro argilo arenoso (bra/ra); maciço que se rompe em fragmentos irregulares, fraco; muito friāvel, ligeiramente plāstico, ligeiramente pegajosoi raízes finas, poucas; poros médios, verticais, contínuos, abun dantes.

OBSERVAÇAOO: $\quad$ Pontes de argila no Bsql e Bsq2.

ALTITUDE: $\quad 520$ metros. 
82.

PEDON 2

CLASSIFICAÇAO: P IDZŐLICO VERMELHO AMARELO PLINTICO, EPIEUTRŐFICO; ĀIiCO, A msderado, textura argilosa.

LOCALIZAÇAO: Eitrade Pirapora-Montes Claros aproximadamente a $1 \mathrm{~km}$ de Gıaicu" penetrando-se a esquerda por uma secundāria cerca de $2.000 \mathrm{~m}$.

GEOLOGIA: Quaternārio-Holoceno.

MATERIAL DE ORIGEM: Sedimentos argilo-arenosos retrabalhados.

RELEVO LOCAL: Plano.

RELEVO REGIONAL: Plano a levemente deprimido.

VEGETAÇAO: $\quad$ Floresta caducifolia transição a cerrado.

DRENAGEM: Imperfeita.

MORFOLOGIA:

Al 0 - $8 \mathrm{~cm}$; pardo acinzentado muito escuro (10YR 3/2 úmido); barro arenoso (ba); blocos subangulares, médios a finos, moderado; muito friāvel, ligeiramente plāstico, ligeiramente pegajoso; raizes muito finas, abundantes, mēdias poucas; galerias bio 1ōgicas menores que $5 \mathrm{~mm}$, poucas; poros finos, caōticos, des contínuos, abundantes; limite ondulado, claro. 
Btl 8. $38 \mathrm{~cm}$; pardo forte (7,5YR 5/6 úmido); barro argiloso (ra): pris mático grandes; friāvel, muito plāstico, muito pegajoso ; raizes finas, raras; galerias biológicas menores que $10 \mathrm{~mm}$, comuns; poros finos e mēdios verticais, descontĩnuos, abun dantes; acumulação ferruginosa em $5 \%$, alaranjado ( 5 YR $5 / \overline{8})$; limite ondulado, gradual.

Bt2 38-100 cm; matriz amarelo avermelhado (7,5YR 6/8 úmido) com $20 \%$ ver melho (2,5YR 4/6), médios, irregulares, distinto, brusco; barro argiloso $(r / r l)$ : prismas médios grandes, fraco; mui to friāvel, muito plástico, muito pegajoso: raízes muito fí nas, raras: galerias biolögicas menores que $5 \mathrm{~mm}$, comuns i poros médios, oblĩquos, descontínuos, abundantes; acumula ções vermelhas de ferro e argila, comuns e de argila em galerias grandes cimentando quartzo fino; limite ondulado,gra dual.

Cpn 100-140+cm; matriz amarelo avermelhado (7,5YR 6/6 úmido); com $30 \%$ vermelho $(2,5 Y R 4 / 6)$ e $10 \%$ pardo muito pālido (10YR $7 / 3)$, pequenos a médios, distintos; barro argiloso $(r)$; prismātica média, fraca; muito friāvel, muito plāstico, muito pegajoso: raízes finas raras; poros finos e médios caōticos, abundantes; acumulação de ferro em forma concrecionāria, ir regulares, menores que $20 \mathrm{~mm}$.

OBSERVACÃO: Btl cerosidade caótica como películas finas pouca. Bt2 ce. rosidade nos planos verticais como películas comuns, modera da. 
84.

PEDON 3

CLASSIFICAÇÃO: LATERITA HIDROMORFICA, EPIEUTROFICO, Alico, A moderado, tex tura média.

LOCALIZAÇAO: Estrada Pirapora-Montes Claros aproximadamente $1 \mathrm{~km}$ de Guai cuī penetrando-se a esquerda por uma secundāria, cerca dé $2.800 \mathrm{~m}$.

GEOLOGIA: Quaternārio-Holoceno.

MATERIAL DE ORIGEM: Sedimentos argilosos retrabalhados.

RELEVO LOCAL: Plano.

RELEVO REGIONAL: Plano, com āreas deprimidas.

VEGETACÁO: Campina de vārzea associada a āreas de cerrado ralo e de porte baixo.

DRENAGEM: Impedida.

MORFOLOGIA:

Al 0- $8 \mathrm{~cm}$; pardo escuro (10YR 4/3 úmido); barro argilo limoso (brl/ r1); blocos subangulares médios e finos, moderado; friāvel. muito plāstico, muito pegajoso; raĩzes finas e muito finas, abundantes; galerias biológicas maiores que $10 \mathrm{~mm}$, abundantes; poros médios e finos, caóticos, descontīnuos, abundantes; limite ondulado, claro. 
Bt1 8- $34 \mathrm{~cm}$; matriz pardo amarelo claro (10YR 6/4 ümido), com $15 \%$ ver melho $(2,5 Y R 5 / 8)$, pequeno, distinto; barro argilo limoso $(r 1)$; blocos subangulares médios e grandes, forte; friāvel, muito plástico, muito pegajoso; cerosidade fraca, pouca em alguns planos; raizes muito finas, poucas; galerias biológi cas menores que $10 \mathrm{~mm}$. comuns, algumas com preenchimento de argila cimentando areia fina; poros finos, caóticos, descon tinuos, abundantes: limite ondulado, claro.

Bt2 34- $89 \mathrm{~cm}$; matriz pardo muito pālido (10YR $7 / 3$ úmido) com $15 \%$ vermelho $(2,5 Y R 5 / 8)$ de acumulação de ferro, médios, distintos; arqilo limoso ( $r l)$; prismática grande que se rompe em blocos médios e grandes, moderado; friāvel, muito plástico,mui to pegajoso; galerias biológicas menores que $10 \mathrm{~mm}$, comuns; poros médios, caóticos, descontinuos, abundantes; acumula ções ferruginosas vermelhas; limite ondulado, gradual.

2Cpn 89-150+cm; matriz pardo muito pālido (10YR $7 / 3$ ümido) com $30 \%$ vermelho (2,5YR 5/8); ferruginosas, distintas, abrupto; barro argiloso (ra); prismática grande que se rompe em blocos sub angulares médios, moderado; friāvel, muito plāstico, muitō pegajoso; poros médios, caóticos, descontínuos, abundantes; acumulações de ferro em áreas irregulares, vermelhas; seixos quartziticos menores que $20 \mathrm{~mm}$ dispersos no horizonte.

OBSERVAÇAO: Bt2 apresenta crotovinas menores que $30 \mathrm{~mm}$ na base, comuns. 
PEDON 4

CLASSIFICACAO: PODZOLICO VERMELHO AMARELO PLINTICO, EPIEUTROFICO, AliCO, A moderado, textura barro argilo limosa.

LOCALIZAÇA: Estrada Pirapora-Montes Claros aproximadamente $7 \mathrm{~km}$ de Guai cuî penetrando-se a esquerda cerca de $3,8 \mathrm{~km}$ por uma secundāria.

GEOLOGIA: Quaternārio-Holoceno.

MATERIAL DE ORIGEM: Sedimentos argilosos retrabalhados.

RELEVO LOCAL: Plano.

RELEVO REGIONAL: Plano.

VEGETAÇAO: Floresta caducifolia transição a cerrado.

DRENAGEM: Imperfeita.

MORFOLOGIA:

Al

0- $7 \mathrm{~cm}$; pardo escuro (10YR 4/3 úmido); barro limoso (b1); compos ta, blocos subangulares médios, moderado e granular pequena a média, moderada; friāvel, plástico a pegajoso; raízes médias e grossas, abundantes; galerias biológicas menores que $10 \mathrm{~mm}$, abundantes; limite ondulado, claro. 
B/A 7- $19 \mathrm{~cm}$; pardo (10YR $5 / 3$ úmido) com $15 \%$ de pardo avermelhado es curo $(2,5 Y R 3 / 4)$, pequeno a médio, distinto e $10 \%$ amarelo avermelhado $(7,5 Y R$ 6/8), pequeno, distinto; barro limoso $(r)$; blocos subangulares médios e pequenos, moderadc; muito fria vel, muito plástico, muito pegajoso; raĩzes finas e médias abundantes; galerias biológicas menores que $10 \mathrm{~mm}$, abundantes; poros finos e médios, caóticos, descontínuos, abundantes; concreções de ferro e argila, aumentando quartzo; acumulações de argila e quartzo fino em galerias; limite ondulado, gradual.

Btl 19. $57 \mathrm{~cm}$; matriz pardo amarelado (10YR $5 / 4$ úmido) com $30 \%$ pardo avermelhado escuro $(2,5 Y R 3 / 4)$, médio, distinto , brusco;bar ro argilo limoso $(r 1)$; prismática que se rompe em blocos subangulares médios, moderado; muito friāvel, muito plásti. co, muito pegajoso; cerosidade forte, por planos verticais e horizontais, abundantes; raĩzes médias, comuns; galerias biológicas menores que $10 \mathrm{~mm}$, comuns; poros finos e médios, oblīquos, descontínuos, comuns; concreções plinticas, $30 \%$; limite ondulado, claro.

Btpn2 $57-79 \mathrm{~cm}$; matriz amarelo avermelhado $(7,5 Y R \quad 6 / 8)$ com $30 \%$ verme tho (2,5YR 4/8), médio, distinto, brusco; barro argilo limoso (rl) prismática grande, forte; friāvel, muito plástico, mui to pegajoso; cerosidade moderada, planos verticais e hori zontais, películas finas, abundantes; raízes finas e poucas; galerias biológicas menores que $10 \mathrm{~mm}$ preenchidas com argila cimentando quartzo fino, comuns; poros médios, oblíquos, descontinuos, abundantes, concreções plinticas menores que $4 \mathrm{~mm}$, comuns; limite ondulado, abrupto. 
2C $\quad 79.115 \mathrm{~cm}$; amarelo avermelhado (7,5VR 6/6 úmido); barro arenoso (ba); maciço; muito friavel, não plástico, ligeiramente pegajoso; pontes de argila esparsas; raizes finas, poucas; galerias biológicas menores que $3 \mathrm{~mm}$ raras; poros médios, verticais e oblíquos, comuns; limite ondulado, abrupto.

3Cpn 115-240+cm; matriz vermelho escuro (2,5YR 3/6 úmido) com $40 \%$ pardo muito pālido (lOYR $7 / 3$ ) e preto (N2/) de manganês, $2 \%$, dis tintos, abruptos; barro limoso $(r)$; prismática média a gran de, forte; friāvel, muito plástico, muito pegajoso; raizes muito finas, poucas; poros finos, caóticos, descontīnuos, abundantes; concreções e nódulos de argila com manganês no centro.

OBSERVACAO: Nos ūltimos $50 \mathrm{~cm}$ com cor de matriz pardo muito pālido (10YR 7/3) e com $40 \%$ (5YR 4/8) médios, distintos, abrupto, com canais absorventes em cujas paredes se depositam manganês $(\mathrm{N} 2 /)$. 
89.

PEDON 5

CLASSIFICACAO: BRUNIZEM AVERMELHADO, textura siltosa.

LOCALIZACAO: Estrada Pirapora-Montes Claros aproximadamente $1 \mathrm{~km}$ de Guai cū̄, pelo lado esquerdo em estrada secundāria por $5,5 \mathrm{~km} \overline{\mathrm{e}}$ a 250 metros da margem direita do rio São Francisco.

GEOLOGIA: Quaternārio-Holoceno.

MATERIAL DE ORIGEM: Sedimentos argilo-limosos fluviais.

RELEVO LOCAL: Plano.

RELEVO REGIONAL: Plano.

VEGETAÇAO: Floresta ciliar.

DRENAGEM: $\quad$ Boa.

MORFOLOGIA:

Al $\quad 0-10 \mathrm{~cm}$; pardo acinzentado muito escuro (10YR 3/2 úmido); barro limoso (bra/br); blocos subangulares médios e finos, forte; friāvel, plāstico, pegajoso; raizes grossas a finas, abun dantes, muito grossas, raras; galerias biológicas menores que $10 \mathrm{~mm}$ algumas preenchidas com material preto $(\mathrm{N} /)_{8}$ abun dantes; poros médios, caōticos , descontínuos, abundantes ; carvões pequenos, comuns; limite transitando gradualmente. 
A2 10. $40 \mathrm{~cm}$; pardo acinzentado muito escuro (10YR $3 / 2$ úmido); barro limoso (br); blocos subangulares médios e grandes, forte ; friāvel, plāstico, pegajoso; raĩzes grossas a finas, abun dantes; galerias biológicas menores que $10 \mathrm{~mm}$ abundantes,al gumas preenchidas com material preto (N2/); poros médios $\bar{e}$ finos; horizontais e oblíquos, contínuos, abundantes; carvões pequenos, raros; limite ondulado, gradual.

Btl 40. $82 \mathrm{~cm}$; pardo escuro (7,5YR 4/4 úmido); barro limoso (R); prismá tica média, moderada; friavel, muito plástico, muito pegajoso; cerosidade moderada, planos verticais e horizontais; pe liculas mēdias, abundantes; raízes finas, comuns; galerias biológicas menores que $10 \mathrm{~mm}$, comuns; poros médios, descontínuos, caóticos, abundantes; limite ondulado, gradual.

Bt2 82-140+cm; alaranjado (5YR 4/6 úmido); barro ( $r a)$; maciço que se rompe em fragmentos irregulares; firme, plāstico, pegajoso; cerosidade fraca nos planos verticais e horizontais, pelicu las finas, comuns; raizes finas, poucas; galerias biológi cas menores que $5 \mathrm{~mm}$, poucas; poros finos e médios, caōti $\cos$, descontinnuos, comuns, limite ondulado, gradual.

2C 140-200 cm; amarelo avermelhado (7,5YR 6/6); areia barrenta (ab); ma ciço, muito friável, não plástico, não pegajoso.

ALTITUDE: $\quad 400$ metros. 
PEDON I

\begin{tabular}{|c|c|c|c|c|c|c|c|}
\hline \multicolumn{2}{|c|}{ Horizonte } & \multicolumn{2}{|c|}{ Dens idade } & \multirow{2}{*}{$\begin{array}{l}\text { VPT } \\
\%\end{array}$} & \multirow{2}{*}{$\begin{array}{l}\text { Grau } \\
\text { Floc. } \\
\%\end{array}$} & \multirow{2}{*}{$\frac{\text { Umidade }}{1 / 3}$} & \multirow{2}{*}{$\frac{\% \text { tensões }}{15}$} \\
\hline Simbolo & Prof. $(\mathrm{cm})$ & $\mathrm{Da}$ & $D r$ & & & & \\
\hline Al & $0-12$ & 1,6 & 2,5 & 35 & 36 & 9 & 3 \\
\hline Bsql & $12-32$ & 1,7 & 2,6 & 35 & 17 & 12 & 5 \\
\hline Bsq2 & $32-92$ & 1,8 & 2,5 & 31 & 92 & 15 & 6 \\
\hline$B / C$ & $92-150$ & 1,5 & 2,6 & 43 & 95 & 12 & 8 \\
\hline
\end{tabular}

\begin{tabular}{|c|c|c|c|c|c|c|c|c|}
\hline \multirow[b]{2}{*}{$\mathrm{mg}$} & \multirow{2}{*}{\multicolumn{2}{|c|}{$\frac{\text { Areia }}{m}$}} & \multicolumn{2}{|l|}{$\%$} & \multirow{2}{*}{$\begin{array}{c}\text { Limo } \\
\%\end{array}$} & \multicolumn{2}{|c|}{ Argila } & \multirow{2}{*}{$\begin{array}{l}\text { Classe } \\
\text { text. }\end{array}$} \\
\hline & & & $f$ & $m f$ & & Total & Disp. & \\
\hline 1,2 & 8,4 & 30,6 & 29,5 & 10,1 & 10.6 & 9,6 & 6,2 & $a b$ \\
\hline 1,5 & 7,8 & 27,2 & 26,6 & 8,1 & 16,4 & 12,4 & 10,2 & ba \\
\hline 1,5 & 10,2 & 26,2 & 20,8 & 8,6 & 13,6 & 19,1 & 1,6 & ba \\
\hline 1,1 & 7,8 & 21,6 & 23,2 & 12,5 & 12,7 & 21,1 & 1,0 & bra \\
\hline
\end{tabular}

CTC Complexo sortivo (e.mg/100 g)

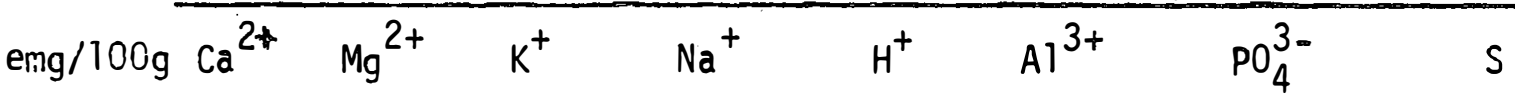

\begin{tabular}{lllllllll}
\hline 1,58 & 0,36 & 0,33 & 0,18 & 0,02 & 0,25 & 0,44 & 0,03 & 0,9 \\
1,38 & 0,07 & 0,20 & 0,08 & 0,02 & 0,37 & 0,64 & 0,01 & 0,4 \\
1,54 & 0,07 & 0,31 & 0,06 & 0,02 & 0,41 & 0,67 & 0,01 & 0,5 \\
1,71 & 0,07 & 0,27 & 0,31 & 0,02 & 0,24 & 0,80 & 0,01 & 0,8
\end{tabular}

\begin{tabular}{|c|c|c|c|c|c|c|c|}
\hline \multirow{2}{*}{$\begin{array}{l}\mathrm{V} \\
\%\end{array}$} & \multicolumn{2}{|c|}{$\mathrm{pH}(1: 1)$} & \multirow{2}{*}{$\begin{array}{l}\text { Acidez } \\
\text { CaOAC }\end{array}$} & \multirow{2}{*}{$\begin{array}{l}\mathrm{C} \\
\%\end{array}$} & \multirow{2}{*}{$\begin{array}{l}\text { MO } \\
\%\end{array}$} & \multirow{2}{*}{$\begin{array}{l}\mathrm{Fe}_{2} \mathrm{O}_{3} \\
\text { livre- } \%\end{array}$} & \multirow{2}{*}{$\begin{array}{c}\mathrm{V}_{\mathrm{Al}} \\
\%\end{array}$} \\
\hline & $\mathrm{H}_{2} \mathrm{O}$ & $\mathrm{KCl}$ & & & & & \\
\hline 56 & 4,3 & 3,5 & 2,9 & 0,6 & 1,0 & 1.0 & 28 \\
\hline 27 & 4,0 & 3,4 & 2,6 & 0,4 & 0,7 & 1.4 & 46 \\
\hline 30 & 4,1 & 3,4 & 2,7 & 0,2 & 0,3 & 1.7 & 43 \\
\hline 39 & 3,9 & 3,4 & 2,6 & 0,2 & 0,3 & 1,6 & 47 \\
\hline
\end{tabular}


PEDON 2

\begin{tabular}{|c|c|c|c|c|c|c|c|}
\hline \multicolumn{2}{|c|}{ Horizonte } & \multicolumn{2}{|c|}{ Densidade } & \multirow{2}{*}{$\begin{array}{c}\text { VPT } \\
\%\end{array}$} & \multirow{2}{*}{$\begin{array}{c}\text { Grau } \\
\text { Floc. } \\
\%\end{array}$} & \multicolumn{2}{|c|}{ Umidade \% tensões } \\
\hline Símbolo & Prof. $(\mathrm{cm})$ & $\mathrm{Da}$ & Dr & & & $1 / 3$ & 15 \\
\hline$\overline{A 1}$ & $0-8$ & 1,8 & 2,5 & 30 & 42 & 14 & 6 \\
\hline$B t l$ & $8-38$ & 1,7 & 2,6 & 36 & 94 & 19 & 10 \\
\hline Bt2 & $38-100$ & 1,6 & 2,6 & 40 & 97 & 24 & 12 \\
\hline Cpn & $100-140$ & 1,7 & 2,6 & 34 & 97 & 28 & 13 \\
\hline
\end{tabular}

\begin{tabular}{|c|c|c|c|c|c|c|c|c|}
\hline \multicolumn{5}{|c|}{ Areia \% } & \multirow{2}{*}{$\begin{array}{l}\text { Limo } \\
\%\end{array}$} & \multicolumn{2}{|c|}{ Argila } & \multirow{2}{*}{$\begin{array}{l}\text { Classe } \\
\text { text. }\end{array}$} \\
\hline $\mathrm{mg}$ & g & $m$ & $f$ & $\mathrm{mf}$ & & Total & Disp. & \\
\hline 0,4 & 2,6 & 13,8 & 30,2 & 8,1 & 33.0 & 11,9 & 6,9 & $\mathrm{ba}$ \\
\hline 0,2 & 2,0 & 9,9 & 22,9 & 6,5 & 29,9 & 28,6 & 1,5 & $b r$ \\
\hline 0,5 & 1,3 & 5,1 & 15,5 & 5,3 & 34,5 & 37,8 & 1,0 & $b r$ \\
\hline 0,4 & 1,5 & 4,1 & 12,6 & 6,3 & 43,6 & 31,5 & 1,0 & $b r$ \\
\hline
\end{tabular}

\begin{tabular}{lcccccccc}
\hline \multirow{2}{*}{ CTC } & \multicolumn{7}{c}{ Complexo sortivo (e.mg/100 g) } \\
\cline { 2 - 8 } e.mg/100g & $\mathrm{Ca}^{2+}$ & $\mathrm{Mg}^{2+}$ & $\mathrm{K}^{+}$ & $\mathrm{Na}^{+}$ & $\mathrm{H}^{+}$ & $\mathrm{Al}^{3+}$ & $\mathrm{PO}_{4}^{3-}$ & $\mathrm{S}$ \\
\hline 3,51 & 1,46 & 0,84 & 0,74 & 0,04 & 0,17 & 0,26 & 0,05 & 3,1 \\
3,44 & 0,18 & 0,45 & 0,74 & 0,02 & 0,34 & 1,71 & 0,01 & 1,4 \\
3,30 & 0,12 & 0,19 & 0,45 & 0,02 & 0,33 & 2,19 & 0,01 & 0,8 \\
2,89 & 0,12 & 0,14 & 0,20 & 0,02 & 0,28 & 2,13 & 0,02 & 0,5
\end{tabular}

\begin{tabular}{|c|c|c|c|c|c|c|c|}
\hline \multirow{2}{*}{$\begin{array}{l}\mathrm{V} \\
\%\end{array}$} & \multicolumn{2}{|c|}{$\mathrm{pH}(1: 1)$} & \multirow{2}{*}{$\begin{array}{l}\text { Acidez } \\
\text { CaOAC }\end{array}$} & \multirow{2}{*}{$\begin{array}{l}C \\
\%\end{array}$} & \multirow{2}{*}{$\begin{array}{l}\text { MO } \\
\%\end{array}$} & \multirow{2}{*}{$\begin{array}{l}\mathrm{Fe}_{2} \mathrm{O}_{3} \\
\text { livre } \%\end{array}$} & \multirow{2}{*}{$\begin{array}{l}V_{A 1} \\
\%\end{array}$} \\
\hline & $\mathrm{H}_{2} \mathrm{O}$ & $\mathrm{KCl}$ & & & & & \\
\hline 88 & 4,6 & 3,7 & 3,7 & 1,1 & 1,9 & 0,8 & 7 \\
\hline 40 & 4,2 & 3,2 & 4.7 & 0,3 & 0,5 & 1.1 & 50 \\
\hline 24 & 4,0 & 3,2 & 5,2 & 0,3 & 0,5 & 1,6 & 66 \\
\hline 17 & 4,1 & 3,3 & 5,3 & 0,2 & 0,3 & 289 & 74 \\
\hline
\end{tabular}


PEDON 3

\begin{tabular}{|c|c|c|c|c|c|c|c|}
\hline \multicolumn{2}{|c|}{ Horizonte } & \multicolumn{2}{|c|}{ Densidade } & \multirow{2}{*}{$\begin{array}{c}\text { VPT } \\
\%\end{array}$} & \multirow{2}{*}{$\begin{array}{c}\text { Grau } \\
\text { Floc. } \\
\%\end{array}$} & \multicolumn{2}{|c|}{ Umidade $\%$ tensões } \\
\hline Símbolo & Prof. $(\mathrm{cm})$ & $\mathrm{Da}$ & $D r$ & & & $1 / 3$ & 15 \\
\hline$\overline{A 1}$ & $0-8$ & 1,3 & 2,2 & 43 & 41 & 38 & 23 \\
\hline$B t l$ & $8-34$ & 1,5 & 2,4 & 38 & 94 & 36 & 23 \\
\hline Bt2 & $34-89$ & 1,4 & 2,6 & 47 & 97 & 40 & 25 \\
\hline $2 C p n$ & $89-150$ & 1,7 & 2,7 & 36 & 96 & 26 & 15 \\
\hline
\end{tabular}

\begin{tabular}{|c|c|c|c|c|c|c|c|c|}
\hline \multicolumn{5}{|c|}{ Areia \% } & \multirow{2}{*}{$\begin{array}{c}\text { Limo } \\
\%\end{array}$} & \multicolumn{2}{|c|}{ Argila } & \multirow{2}{*}{$\begin{array}{l}\text { Classe } \\
\text { text. }\end{array}$} \\
\hline $\mathrm{mg}$ & $g$ & $m$ & $f$ & $m f$ & & Total & Disp. & \\
\hline - & 0,5 & 0,8 & 1,1 & $\theta, 7$ & 60,7 & 36,2 & 21,3 & $b r l$ \\
\hline- & 0,2 & 0,8 & 1,4 & 1,0 & 62,1 & 34,5 & 2,2 & brl \\
\hline- & 0,1 & 0,5 & 1,0 & 1,0 & 56,8 & 40,6 & 1,0 & $r l$ \\
\hline 0,4 & 0,9 & 7,0 & 18,0 & 8,2 & 36,4 & 29,1 & 1,0 & br \\
\hline
\end{tabular}

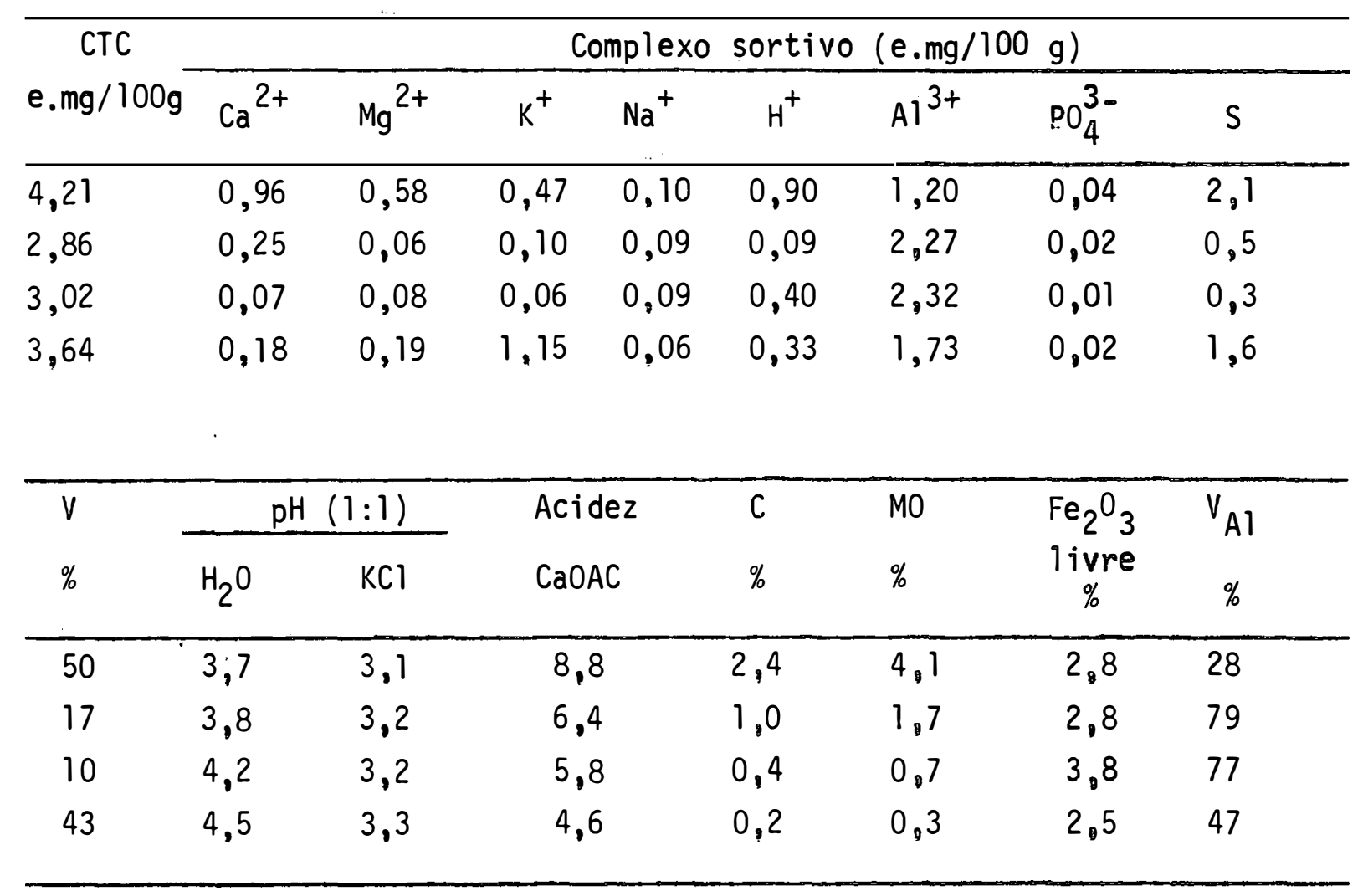


PEDON 4

\begin{tabular}{|c|c|c|c|c|c|c|c|}
\hline \multicolumn{2}{|c|}{ Horizonte } & \multicolumn{2}{|c|}{ Dens i dade } & \multirow{2}{*}{$\begin{array}{c}\text { VPT } \\
\%\end{array}$} & \multirow{2}{*}{$\begin{array}{l}\text { Grau } \\
\text { Floc. } \\
\%\end{array}$} & \multicolumn{2}{|c|}{ Umidade \% tensões } \\
\hline Símbolo & Prof. $(\mathrm{cm})$ & $\mathrm{Da}$ & Dr & & & $1 / 3$ & 15 \\
\hline $\begin{array}{l}A 1 \\
B / A \\
B t 1 \\
\text { Btpn2 } \\
2 C \\
3 C p n\end{array}$ & $\begin{array}{r}0-7 \\
7-19 \\
19-57 \\
57-79 \\
79-115 \\
115-140\end{array}$ & $\begin{array}{l}1,4 \\
1,5 \\
1,4 \\
1,6 \\
1,7 \\
1,7\end{array}$ & $\begin{array}{l}2,4 \\
2,3 \\
2,6 \\
2,6 \\
2,5 \\
2,6\end{array}$ & $\begin{array}{l}39 \\
36 \\
44 \\
39 \\
30 \\
37\end{array}$ & $\begin{array}{l}32 \\
44 \\
97 \\
96 \\
88 \\
92\end{array}$ & $\begin{array}{l}24 \\
21 \\
24 \\
23 \\
19 \\
14\end{array}$ & $\begin{array}{l}16 \\
12 \\
14 \\
13 \\
17 \\
12\end{array}$ \\
\hline
\end{tabular}

\begin{tabular}{|c|c|c|c|c|c|c|c|c|}
\hline \multicolumn{5}{|c|}{ Areia \% } & \multirow{2}{*}{$\begin{array}{l}\text { Limo } \\
\%\end{array}$} & \multicolumn{2}{|c|}{ Argila } & \multirow{2}{*}{$\begin{array}{l}\text { Classe } \\
\text { text. }\end{array}$} \\
\hline $\mathrm{mg}$ & $g$ & $m$ & $f$ & $\mathrm{mf}$ & & Total & Disp. & \\
\hline $\begin{array}{l}0,3 \\
0,4 \\
0,9 \\
0,4 \\
1,3 \\
0,2\end{array}$ & $\begin{array}{l}3,5 \\
3,2 \\
2,6 \\
3,1 \\
7,8 \\
1,5\end{array}$ & $\begin{array}{r}10,4 \\
9,8 \\
6,6 \\
10,3 \\
33,2 \\
10,9\end{array}$ & $\begin{array}{r}4,4 \\
4,3 \\
3,1 \\
3,7 \\
17,2 \\
9,8\end{array}$ & $\begin{array}{r}1,9 \\
1,4 \\
2,5 \\
0,7 \\
5,4 \\
10,1\end{array}$ & $\begin{array}{l}56,7 \\
55,6 \\
49,7 \\
50,0 \\
24,7 \\
51,2\end{array}$ & $\begin{array}{l}22,8 \\
25,3 \\
34,6 \\
31,8 \\
10,4 \\
16,3\end{array}$ & $\begin{array}{r}15,5 \\
14,3 \\
1,2 \\
1,3 \\
1,3 \\
1,3\end{array}$ & $\begin{array}{l}\text { bl } \\
\text { bl } \\
\text { brl } \\
\text { brl } \\
\text { ba } \\
\text { bl }\end{array}$ \\
\hline
\end{tabular}

\begin{tabular}{lcccccccc}
\hline \multirow{2}{*}{ CTC } & \multicolumn{8}{c}{ Complexo sortivo (e.mg/100 g) } \\
\cline { 2 - 9 } & $\mathrm{Ca}^{2+}$ & $\mathrm{Mg}^{2+}$ & $\mathrm{K}^{+}$ & $\mathrm{Na}^{+}$ & $\mathrm{H}^{+}$ & $\mathrm{Al}^{3+}$ & $\mathrm{P0}_{4}^{3-}$ & $\mathrm{S}$ \\
\hline 5,13 & 2,49 & 1,43 & 0,45 & 0,05 & 0,31 & 0,40 & 0,04 & 4,4 \\
$3,35^{-}$ & 0,90 & 0,34 & 0,20 & 0,03 & 0,08 & 1,80 & 0,01 & 1,5 \\
3,95 & 0,30 & 0,27 & 0,15 & 0,05 & 0,31 & 2,87 & 0,02 & 0,8 \\
1,98 & 0,12 & 0,11 & 0,07 & 0,05 & 0,45 & 1,18 & 0,01 & 0,3 \\
0,92 & 0,12 & 0,08 & 0,04 & 0,04 & 0,09 & 0,55 & 0,08 & 0,3 \\
2,05 & 0,18 & 0,34 & 0,12 & 0,12 & 0,09 & 1,26 & 0,02 & 0,7
\end{tabular}

\begin{tabular}{|c|c|c|c|c|c|c|c|}
\hline \multirow{2}{*}{$\begin{array}{l}V \\
\%\end{array}$} & \multicolumn{2}{|c|}{$\mathrm{pH}(1: 1)$} & \multirow{2}{*}{$\begin{array}{l}\text { Aci dez } \\
\text { CaOAC }\end{array}$} & \multirow{2}{*}{$\begin{array}{l}C \\
\%\end{array}$} & \multirow{2}{*}{$\begin{array}{r}\text { MO } \\
\%\end{array}$} & \multirow{2}{*}{$\begin{array}{l}\mathrm{Fe}_{2} \mathrm{O}_{3} \\
\text { livre }\end{array}$} & \multirow{2}{*}{$\begin{array}{c}\mathrm{V}_{\mathrm{Al}} \\
\%\end{array}$} \\
\hline & $\mathrm{H}_{2} \mathrm{O}$ & $\mathrm{KCl}$ & & & & & \\
\hline $\begin{array}{l}86 \\
44 \\
19 \\
18 \\
30 \\
34\end{array}$ & $\begin{array}{l}4,6 \\
4,2 \\
4,3 \\
4,4 \\
4,5 \\
4,8\end{array}$ & $\begin{array}{l}3,5 \\
3,2 \\
3,2 \\
3,4 \\
3,6 \\
3,4\end{array}$ & $\begin{array}{l}7,2 \\
6,0 \\
6,6 \\
6,1 \\
2,6 \\
3,6\end{array}$ & $\begin{array}{l}2,3 \\
0,9 \\
0,5 \\
0,4 \\
0,1 \\
0,1\end{array}$ & $\begin{array}{l}3,9 \\
1,5 \\
0,8 \\
0,7 \\
0,2 \\
0,2\end{array}$ & $\begin{array}{l}2,5, \\
2,9 \\
3,7 \\
4,1 \\
1,6 \\
2,7\end{array}$ & $\begin{array}{r}8 \\
54 \\
73 \\
59 \\
60 \\
61\end{array}$ \\
\hline
\end{tabular}


PEDON 5

\begin{tabular}{|c|c|c|c|c|c|c|c|}
\hline \multicolumn{2}{|c|}{ Horizonte } & \multicolumn{2}{|c|}{ Densidade } & \multirow{2}{*}{$\begin{array}{c}\text { VPT } \\
\%\end{array}$} & \multirow{2}{*}{$\begin{array}{l}\text { Grau } \\
\text { Floc. } \\
\%\end{array}$} & \multicolumn{2}{|c|}{ Umidade \% tensões } \\
\hline Símbolo & Prof. $(\mathrm{cm})$ & $\mathrm{Da}$ & $D r$ & & & $1 / 3$ & 15 \\
\hline Al & $0-10$ & 1,4 & 2,3 & 42 & 23 & 23 & 22 \\
\hline$A 2$ & $10-40$ & 1,6 & 2,5 & 34 & 35 & 18 & 17 \\
\hline Btl & $40-82$ & 1,6 & 2,6 & 37 & 32 & 17 & 16 \\
\hline Bt2 & $82-140$ & 1,8 & 2,6 & 33 & 86 & 9 & 9 \\
\hline $2 C$ & $140-200$ & 1,5 & 2,6 & & & & \\
\hline
\end{tabular}

\begin{tabular}{cccccccccc}
\hline & \multicolumn{3}{c}{ Areia $\%$} & & Limo & \multicolumn{2}{c}{ Argila } & \multirow{2}{c}{$\begin{array}{c}\text { Classe } \\
\text { text. }\end{array}$} \\
\hline $\mathrm{mg}$ & $\mathrm{g}$ & $\mathrm{m}$ & $\mathrm{f}$ & $\mathrm{mf}$ & & $\%$ & Total & Disp. & text \\
\hline- & - & 0,9 & 17,6 & 4,3 & & 63,2 & 14,0 & 10,8 & $\mathrm{bl}$ \\
- & - & 1,4 & 22,3 & 6,6 & & 50,9 & 18,8 & 12,2 & $\mathrm{bl}$ \\
- & 0,1 & 1,0 & 20,1 & 2,7 & & 53,4 & 22,7 & 15,4 & $\mathrm{bl}$ \\
- & - & 2,4 & 36,2 & 9,6 & & 33,9 & 17,9 & 2,4 & $\mathrm{~b}$ \\
- & - & 2,6 & 57,6 & 13,8 & & 9,6 & 16,4 & - & ba
\end{tabular}

\begin{tabular}{|c|c|c|c|c|c|c|c|c|}
\hline \multirow{2}{*}{$\begin{array}{c}\text { CTC } \\
\mathrm{e} . \mathrm{mg} / 100 \mathrm{~g}\end{array}$} & \multicolumn{8}{|c|}{ Complexo sortivo (e.mg/100 g } \\
\hline & $\mathrm{Ca}^{2+}$ & $\mathrm{Mg}^{2+}$ & $\mathrm{K}^{+}$ & $\mathrm{Na}^{+}$ & $\mathrm{H}^{+}$ & $\mathrm{Al}^{3+}$ & $\mathrm{PO}_{4}^{3-}$ & S \\
\hline 14,80 & 11,28 & 2,78 & 0,44 & 0,10 & 0,11 & 0,09 & 0,17 & 14,6 \\
\hline 9,00 & 6,07 & 2,23 & 0,42 & 0,08 & 0,11 & 0,09 & 0,08 & 8,8 \\
\hline 6,93 & 3,31 & 2,68 & 0,72 & 0,06 & 0,08 & 0,08 & 0,02 & 6,8 \\
\hline 3,22 & 1,55 & 0,89 & 0,34 & 0,05 & 0,29 & 0,10 & 0,04 & 2,8 \\
\hline V & \multicolumn{2}{|c|}{$\mathrm{pH}(1: 1)$} & \multirow{2}{*}{$\begin{array}{l}\text { Acidez } \\
\text { CaOAC }\end{array}$} & \multirow{2}{*}{$\begin{array}{l}C \\
\%\end{array}$} & \multirow{2}{*}{\multicolumn{2}{|c|}{$\begin{array}{l}\text { MO } \\
\%\end{array}$}} & \multirow{2}{*}{$\begin{array}{l}\mathrm{Fe}_{2} \mathrm{O}_{3} \\
\text { livre }\end{array}$} & \multirow{2}{*}{${ }_{\%}^{\mathrm{Al}}$} \\
\hline$\%$ & $\mathrm{H}_{2} \mathrm{O}$ & $\mathrm{KCl}$ & & & & & & \\
\hline 99 & 6,5 & 5,6 & 2,7 & 4,2 & & 7,1 & 2,3 & 1 \\
\hline 98 & 5,8 & 5,0 & 3,2 & 1,4 & & 2,4 & 2,9 & 1 \\
\hline 98 & 5,8 & 4,8 & 2,8 & 0,6 & & 1,0 & 3,3 & 1 \\
\hline 88 & 4,8 & 3,6 & 2,8 & 0,2 & & $0_{0} 3$ & 2.4 & 3 \\
\hline
\end{tabular}

